\title{
Methodology for Characterizing Potential Adversaries of Nuclear Material Safeguards Systems
}

\author{
This report was prepared for the \\ University of California \\ Lawrence Livermore Laboratory.
}

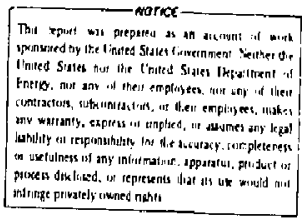

Craig W. Kirkwood

Stephen M. Pollock

November 1978

\section{Woodward-Clyde Consultants}

Three Embarcadero Center. Suite 700. San Francisco. CA 94111 
TABLE OF CONTENTS

\section{PART I - SLMMARY}

1.0 Objectives and Scope of Study 2

1.1 Scope of Study 3

1.2 Scope of Tasks 3

2.0 Overview of Methodology 5

PART II - ANALOGOUS ACTIVITIES

3.0 Analysis of Activitles Analogous to Nuclear Material 14 Safeguards Systems

3.1 Data Sources $\quad 14$

3.2 Documents Obta1ned 17

3.3 Comments on the Usefulness of Analogous $\quad .0$ Activities Data

PART III - DESCRIPTION OF METHODOLOGY 22

4.0 Chatacterization of Potential ddversaries 23

5.0 Ut1lization of Judgmental Information About Adversaries 28

5.1 Theoretical Basis 29

5.1.1 Formulation of Bounding Problem 29

5.1.2 Formulation of Constraints 32

5.2 Computer Implementation 35

6.0 Procedure for Elic1ting Judgmental Information 37

7.0 Preliminary Elicitation Results 38

7.1 Recommended Improvements to Elicitation Process 38

7.2 EIficitation Results 40

$\begin{array}{ll}7.3 \text { Results: Probability Bounds } & 40\end{array}$

8.0 Concluding Comments $\quad 47$

$\begin{array}{ll}\text { REFERENCES } & 48\end{array}$ 


\section{APPENDICES}

A1. Briefing Document 50

A2. Questionnaire 59

A3. Program User's Guide 74

A3.1 Normal Program Run 74

A3.2 Run with Inconsistent Input 76

A4. Translation of Questionnaire Responses Into 84

Program Input Data

A5. Program Documentation 88

A6. Documentation of IBM Mathemat1cal Programming System 91

A7. Program Listings 110 


\section{FIGURES}

Figure 2.1 Adversary Attributes $\quad 6$

Figure 2.2 Definitions of Attribute Levels 7-8

Figure 2.3 IMS System Adversary Archetypes 10-11

F1gure 4.] Coding Scheme for Adversaries 25

Figure 4.2 Exclusion Rules for Impossible or Extremely 26 Unlikely Adversary Descriptions

Figure 4.3 Coded Description of Archetypes 27

Figure 7.1 Marginal Relative Likelihoods 41

Figure 7.2 Conditional Relative Likellhoods 42

Figure 7.3 Bounds on Archetype Probabilities 44

Figure 7.4 Directly Assessed Archetype Probabilities 46

Appendices:

Figure [AI]1 Internal vs. External Losses 54

F1gure [A2]1 Adversary Attributes 69

P1gure [A2]2 Definitions of Attribute Levels 70-71

Figure [A2]3 NMS System Adversary Archetypes $\quad$ 72-73

Figure 14.1 Coded Translation of Judgments of 87 Figures $7.1,7.2$

TABLES

Table A3.1 Normal Drogram Run 
$\int \vdots$

L.

$\Gamma$

1

1

I

PART I

SUMMARY

1

1

i

i.

1

1

\{

1

$\Gamma$

\{

$\int$ 
This report describes the results of a study by Woodwarc-ilyde Consultants to assist the University of California Lawrence Livermore Laboratory in the development of methods to analyze atci evaluate Nuclear Material Safeguards (MMS) Systems. The overall objective of the study by Woodward-Clyde Consultants was to explore the usefulness of two specific approaches to modeling behavior of adversarles of Nuciear Materlal Safeguards Systems:

1. Analysis of data on situations that right be analogous to NMS Systems; and

2. Quantification of the judgment of experts abuut potential adversartes of NMS Systems.

To meet this overall objective, the following three tasks were carried out:

1. Development of a preliminary modeling structure for us a in interviewing experts on adversary behavior;

2. Identification and analysis of situations potentially analogous to MMS Systems; and

3. Interviewing of experts and analysis of the result; of the interviews. 
The scope of work carried out to meet the overall study objective is discussed 1 n more detall below.

\subsection{Scope of Study}

Woodward-Clyde Consultants' study concentrated on developing a methodology to assist experts in describing, in quantitative form, their judgments about the characterfstics of potential adversaries of IMS Systems. Situations potentially analogous to threats to IMS Systems were studied in order to provide background information to assist the experts In quantifying their fudgments. The study did not attempt to use the analysis of ansiogous situations directly to construct models of MMS System adversaries, nor did it attempt to determine the extent and type of threat an adversary with spectfled characteristics would pose to an NMS System.

During the methodology development, a preliminary characterization of MSS System adversaries was determined. Alihough this characterization is presented in this report, it is only a firet-cut at adversary characterization. Its primary use was to ald in methodology developaent. It provides a basis for further discussion of adversaries, but does not represent a firal recoimendation by Woodward-Clyde Consultants regarding characterization of adrersaries.

The scope of work trder each of the three tasks identified above is discussed in the next section.

\subsection{Scupe of Tasks}

Development oi a preliminary zndeling structure for use in interviewIng experts on adversary behavior. A preliminary structure was developed based on the use of judgmental probabilicy assessment methods. In addition, necessary written material was prepared for use in 1nterviews with experts 
on adversary behavior, and computer programs were written to analyze the resuits of the 1nterviews. During the development of the modeifng structures, sequence category definitions provided by Lawrence Liveruore Laboratory were revlewed and modifled for use in this Task.

Identificacton and analysts of situations potentially analogous to NMS Systems, Relevant 11terature and other data sources were analyzed In an attempt to 1dentify quantities or characteristics that were invarient across a wide range of potentially analogous situations. The results were summarized in a briefting document for use by the adversary experts during their Interviews; thus, they had this data avallable to aid them in estimating adversary characteristics.

\section{Interviewing of experts on potential adversaries and analysis of} the results of the interviews. Three experts from Lawrence Livermore Laboratory were interviewed using the materials and methods developed during the earlier two tasks. The results were analyzed with the assistance of computer programs also developed during the earller tasks. Based on the interview results, some modifications were made in the interview procedure. In addition, conclusions were drawn regarding the strengths and limitations of the methodology, and recommendations made for possible future work.

The subjects referred to as "experts" in the paragraph above, and 1n the remainder of this report, are members of the Lawrence Livermore Laboratory Materlal Control and Accountabilfty Project. They have some experience in analyzing the adversary problen but little substantive knowledge about adversartes. Thelr primary use was as subjects to develop Interview procedures; the probability numbers that resulted from interviews with them are for 1llustrative purposes only and do not necessarily represent the views of Latrence Livermore Laboratory or Hoodward-Clyde Consultants. 
Attributes were Introduced that covered the various areas of concern for describing adversaries. These allow the systematic characterization of the various possible adversartes of a NMS system. The process used to determine these attributes is discussed in Section 4,0. The following eight attributes were arrived at: Motivation, NMS System Information, Technical Infornation, Consequence Information, Processing Capability, General Resources, Self-Rlsk Attitude, and Other's-Risk Actitude. The areas of concern covered by eash of these is shown in Figure 2.1.

Four possible levels were defined for the Motivation attribute and two possible levels for each of the other attributes. The definitions of these are given in Figure 2.2. Using this structure, any particular adversary can be described by specifying levels for each of the eight attributes. Thus, for example, one possible adversary would have synbolic motivation; high NMS System, technical, and consequence information; high processing capability and general resources; and a risk-seeking attitude toward both himself and others.

The use of these attributes was motivated by the literature on adversaries $[1,2,4]$, in which discussions use ideas or terms such as "motivation" or "processing capability" when describing adversaries. For convenient use, a methodology to quantify judgments about adversaries by experts should use a means of describing adversaries that is familiar to the experts. 
1. Motivation

2. NWS System Information

3. Technical Information

4. Consequense Information

Reason a theft is attempted

Level of knowledge about the operation of Nuclear Materlal Safeguards Systems

Level of knowledge about nuclear materials, their handling, and their processing

Level of knowledge about possible legal, financial, social, and health consequences of a theft attempt

5. Processing Capability Equipment and expertise avallable to process stolen nuclear material

6. General Resources

Resources, such as equipment and number of personnel, avaliable to ald in theft attempt

7. Self-Risk Attitude Willingness of adversary to risk his own life and welfare

8. Other's-Risk Attitude

Willingness of adversary to risk lives and welfare of those not in the adversary group 
I. Motivation

2. MMS System Information

3. Technical Information
1. Symbolic: For example, game playing, prark, crazy, personal revenge, for princtple, publicity for a cause, cover-up of material unaccounted for

2. Money: To make money by sale of the material or tanson for 1ts safe return

3. Extortion: Theft for nomonetary gain (e.g., political gain, job restitution, prisoner releage)

4. Weapos: Theft to make a weapon for eventual use (e.g., explosive device or radiation dispersal meapop)

1. High: Considerable knowledge of and control over at least one aspect of the Nuclear Material Safeguards System

2. Low: Has only the knowledge avallable to someone outside the NMS System

1. High: Has signtficant knowledge about nuclear science, c Juputer technology, alectronics and related areas

2. Low: Does not have significant knowIedge about these areas

4. Consequence Information 1. E1gh: Full understanding of the possible legal, flnancial, soctal and health consequences of the thef $t$ attempt

2. Low: Incomplete urulerstanding of the possible consequences

1. High: has the equipment and expertise to process stolen matertal, elther to make a weapon or to en-ich or alter it for easier storage or sale.

2. Low: Does not have such capabilities 
6. General Fesources

7. Self-Risk Attitude

8. Other's-Risk Attitude
1. H1gh: A group of people with sone experfence in theft and criminal activity

2. Low: One or two people 1nexperlenced in theft and criminal activity

1. Seeking: Adversary will take chances which threaten his own life or welfare

2. Avolding: Adversary wll not accept significant probability of loss of life or capture

1. Seeking: Adversary is willing to risk IIves and welfare of those not in adversary group

2. Avoiding: Adversary unwilling to do this 
With the attribute levels shown in Figure 2.2, there are $4 \times 2^{7}=512$ different possible adversaries. Thus, to quantify completely an expert's judgments about the relative likelihoods that an MMS System adversary would have various characteristics, it would be necessary to collect 512 different prcbability judgments, one for each possible adversary. In our judgment, this would be difficult to do in a reasonable length of tine and would most likely lead to 1nccnsistent judgments. Therefore, we developed a methodology which allows partial information about these probabilities to be utflized.

The procedure to use parifal probablitty information was directed at the final use intended for the quantitacive information about adversary characteristics: to predict the possible behavior of adversartes toward an MMS System and tbe threat that this behavior poses. In particular, it is desired to find the relative likelihoods of various types of theft attempts (e.g., insider versus outsider thefts, or single individual versus group efforts). Thus, it is not necessary to have probabilities for all 512 different possible adversaries, but only probabilities for selested "types" of adversaries who pose threats of distinctly different theft at tempts.

Using the process discussed in Section 4.0, nineteen adversary archetypes (see Figure 2.3) were defined to characterize the range of possible theft attempts that might be made against an NMS System. Each of these is a combination of some of the 512 different adversaries and each poses a distinctly different type of threat to the system. It is these archetypes for which probabilities are desired for use in the remainder of Lawrence ifverwore Laboratory's work to analyze and evaluate MMS systems. Since there are only nineteen of these, complete information about all of the 512 different adversaries is not zecessary to bound the archetype probabilities tightly. 
1. UnInformed Outsider

2. Principled Outsider

3a. Disgruntled Employee

3b. Disgruntled Employees

4. Principled Executive

5a. Competent Outsider

5b. Competent Outsider Group

6a. Opportunistic Employee

6b. Opportunistic Employees

7. High-Level Embezzling Group
Theft for symbolic reasons, prankster, crazy, for princlple, but not planned; very litt:e Nuclear Material Safeguards System (NMSS) krowledge; technically unsophisticated

Theft for synbolic reasous (e.g., gameplaying, for principle); Iittle or no MUSS knowledga, technically sophisticated; could have considerable diversion zesources, but no inslde contacts

Symbollc theft (e.g., labor unrest, revenge on the system, YaterialUnaccounted-For coverup); MMS System low-level Insider, such as guard, minor techulc1an, talntenance worker, etc.; little technical knowledge

Symbollc theft (e.g., for principle, revenge, coverup of present or future MUF); high level MMSS position and contarcs (executive administrator, etc.); likely to understand consequences of theft; hlgh technical knowledge, possibly a group

Thef $t$ for monetary gain (e.g., future sale); 1ittle or no MSS information; techolcally sophisticated; has diversion resources

Crime of opportunlty, for money; knows one area of MMSS ie.g., guard, lnading dock worker, etc.); little technical sophistication

Possibly loug-term diversion for profit; well-iaformed insiders; technically sophisticated; have WMSS contacts, control and equipment avallable

Figure 2.3 NMS SYSTEM ADVERSARY ARCHE'TYPES 
8. Embezzling Executive Crime of opportunity, possibly long-term diversion; well-informed insider; techaically sophisticated

9. Terroriat Group or Fore1ga National Group

10. Terrorist Individual

11. Insider Terrorist Group

12. Insider Terrorist Ind1vidual

13. Outsider Extortionist Group

14. Outside Expert

15. Extorting Employee

16. Extorting Executive
Theft to bulld weapon; little or no MIS System 1nformation; high technical and processing capability; sophisticated arms and adequate manpower (11kely to mount a direct frontal attack)

Theft to bulld weapon; little or no MMS System information; technically sophisticated and capable of processing material; few theft resourices (Iikely to attack fringe of system, such as material belng transported)

Theft to bufld weapon; well-informed insiders; technically sophisticated with processing capability; have MMS System contacts, control and equipment avallable (may be large group with theft equipment)

Theft to build weapon; well-informed 1usider; technically sophisticated with processing capability; little NMS System control and few contacts (small group or individual)

Theft for extortion; see (5b.) for other characteristics

Theft for extortion; see (5a.) for other characteristics

Theft for extortion; see (6a.), (6́b.) for other characteristics

Thef $t$ for extortion; see (8.) for other characteristics 
A linear programing algorithm, discussed in Section 5.0, was dereloped and programmed for computer use to take as 1 aput partial infomation about the probabilities of different levels of the adversary attributes shown in Figure 2.2. This algorithm computes bounds 1mposed by the partial 1nformation on possible probabilitics for each of the archetypes.

The rationale for collect10g probaillity 1nformation about attribute levels, rather than directly about archetypes, is the supposition that experts are accustomed to shinking in cerms of these attributes. Thus, If questions were asked about the archetypes, the experts would have to informally integrate thefr krowledge about the attribute probabilities to arrive at archetype probabilities. Asking probability questions directly about the attribute levels, and using the computer program to determine archetype probabilities from the attribute information, avolde the possibility of errors in the informal integration.

A questlonnaire and supporting written material, discussed in Section 6.0, were developed to ellcit probability 1nformation from experts. The results obtained by ut1lizing this questionnaire with three experts are discussed in Section 7.0. The work with the three experts showed the methodology can be implemented to collect probability data from experts. However, the fairly wide divergence of judgment among these experts raises loubt.s whether enough agreement can be reached amoug different experts to obtain archetype probab1lities that can defensibly be used in further analyses of NMS Systems. This point, and recomendations for posstble further study, are discussed in Section 8.0. 


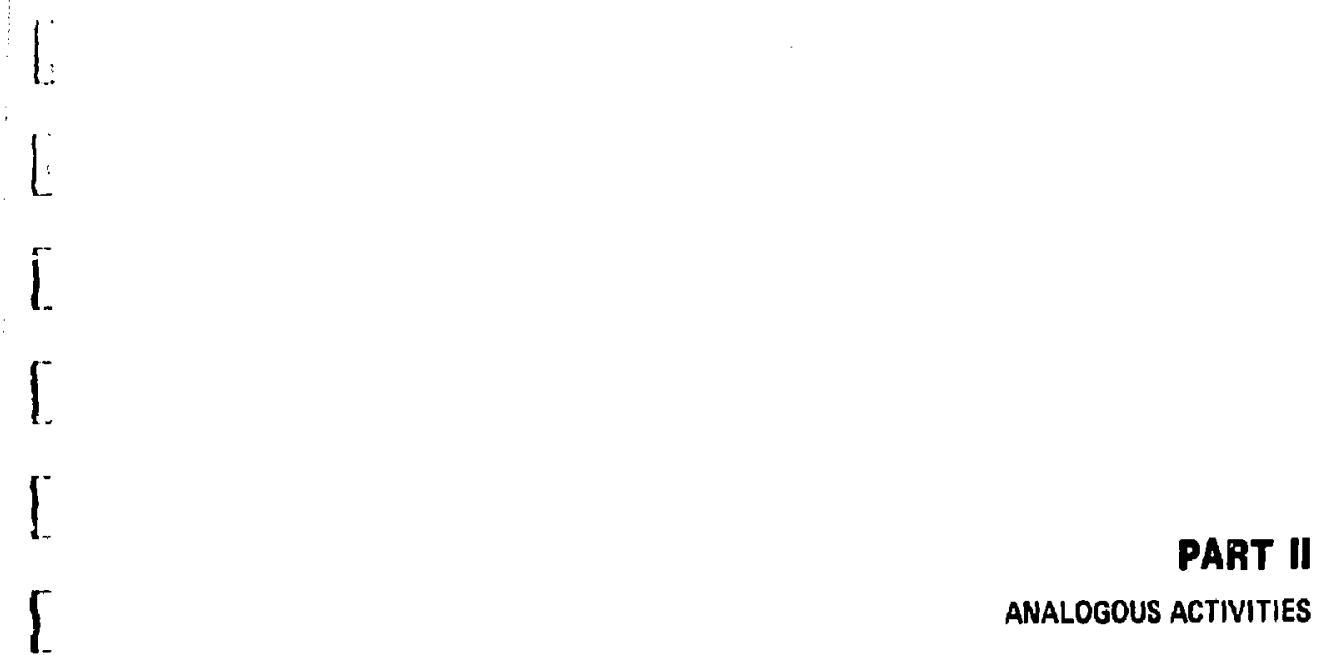

ANALOGOUS ACTIVITIES

T.

I.

\{

1

1

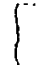

$\Gamma$ 
The investigation of activities analogous to the auclear materfal safeguard situation was designed to provide background information to use In briefing experts on adversartes before interviewing them to quantify their judgments. The results of the analogous activities study are summarized in the Brfefing Document included as Appendix Al to this report. In this section the data sources used are summarized along with the principal documents studled. Finally, some general remarks are made about the usefulness of data on analogous situations.

\subsection{Data Sources}

Because of the linited objectives of our study of analogous activities, only facts and figures already complled by other analysts were utilized. The search for data on analogous activities was initiated by consulting general library sources incleding: Dissertation Abstracts; The New York Times Index; Guide to Ferivuic Literatute; Congressional Information Service Abstracts; Encyclopedia of Organizations. This search identified a number of private and governmental organizations involved in research and/or data collection relevant to analogous security situations. All were contacted by phone. Some organizations requested official LLL or NRC contact before any information, if available, would be released. other groups mailed the desired documents or declined to of fer material for proprietary or security reasons. 
Organizations Contacted

a. Jewelers Secur1ty Ailiance of the U.S. (New York C1ty) Coupiles case historles of jewel thefts, adviges business on protection of jewelsy.

Contact: Mr. James B. What g, President

b. National Crime Prevention Institute (University of Loulsollie, Shel by Campus)

itas NRC contract to study threats to physical security systems at apclear facilities.

Contact: Miss iomar

c. Butres Secur1ty Institute (Briarcliff Manor, N.Y.) Advises the security 1ndustry; has conducted surveys of securlty in varlous industries, facluding banking and electric utilftles. Contact: Mr. B111 Burner

1. Sutety Associatio- of Amerlea (New York City) Compiles statistics on losses of assets in various industries. Cinntact: Mr. Rcbiat bepburn, Jr.

e. American Bankers Assoctation (Washington, D.C.)

Insurance and Protection Division conducts annual survey of losses from member banks; wore detarled data were not avallable despite repeated efforts to obtain wore complete ABA data. Contact: Mr. John Wolff

f. U.S. Chamber of Commerce (Washington, D.C.)

Estimates costs of white collar crime to various industries. 
g. Gmerican Society for Industrial Security (Washington, D.C.) Primary trade organization for security industry: has several standing comittees (Public Ut1lities, Physlcal Security, Terrordsm, Employee Theft, Computer Securily) that are conducting research relevant to our effort.

h. U.S. National Bureau of Standards (Gatthersburg, Md.)

Law Enforcement Standard Laboratory sponsors conierence serfes on "The Role of Behavioral Sciences in Hhysical Sesurity." Papers presented deal with statistical analysis of terrorism (primarily from RANC-Sandia studies) and general adversary studies. Three conferences have been held.

Contact: Joel Cramer.

1. National Criminal justice Reference Service (Washington, D.C.) A clearinghouse for govermental and private criminal justice articles, reports, books, etc.; rperated b7 the Deparimeut of Justice Law Enforcement Assistance Administrat1cn. NCJRS maintalns computer-based bibllographies on private security, Industrial security, terrorism, employee theft and embezlement.

j. Small Business Administration (Washington, D.C.)

Conducted extensive study of losses to small businesses in 1969. Theft from small businesses may not be directly analogous, although the data sources and study methodology provided guidelines for our study of "large" business theft.

\section{k. V.S. Department of Commerce}

The Commerce Department Is the federal agency most responsible for the study of business irime losses and it publishes many. relevant documents. Commerce sponsors a "Crime Against Business" seminar series and publishes statisties on the costs of crime for selected 1ndustries and the economy as a whole. 


\section{Stanford Research Institute}

The Business Intelligence Program of SRI is currently studying crime losses to business; however, release of this data is only sporadle, due to the proprietary nature of the program.

m. Center for Comparative Criminology (University of Montreal) Publishes acaderic papers relating to international criminal treads. The publicatious list did not indicate any research directly related to the purposes of this study.

D. U.S. Department of Justice

The Law Enforcerent Assistance Administration sponsors statistical studies of crime patterns.

\subsection{Documents 0btained}

a. Buras Security Institute

1. National Survey on Pharmaceutical Manufacturing Secur1ty, February 1978.

2. National Survey on Electric Jtilitles Security, January 1976.

3. National Survey on Exhlbition HaII Security, January 1975

4. Nasiona1 Survey on Bank Secur1ty, March 1977.

5. National Survey on Library Security, September 1973.

b. Nat1ona1 Survey on Shoppling Center Security, May 1978. 
b. American Bankers Association

1. Confidential Bank Insurapce Survey, 1977 (first annual survey).

c. Amertcan Soctety for Industrial Security

1. Brian Parker, "Business: Victims of Crime," Security Management, March 1977, pg. 28.

2. Sterling D. Gosset, "Motive anci Opportunity - Embezzlement," Secur1ty Management, March 197$]$.

3. T.S. Department of Commerce, "7he Cost of Crimes Against Business," Security Management March 1975.

4. Robert V. Jacobson, "Finding H:dden Cowputer Crime," Security Management, April 1978, pg. 16!

d. U.S. Kational Bureau of Standards

1. The Roie of Behavorial Sciences in Physical Security, Proceedings, First A.nual Symposium.

2. The Role of Behavioral Sciences in Physical Security, Proceedings, Second Annual Symposium.

e. National Criminal Justice Reference Service

1. Computer-based Bibllographles

- Terrorísa

- Enbezzlement and Employee Theft

- Industrial Security

- Private Security 
2. Security Management Index, July 1957 to January 1977 (ASIS).

3. Industr1a! Secur1ty - a select bibllography comp1led by A.H. Chambers, A.L.A., December 1973.

4. Holdup in Belgique, National Center of Criminology, Bruxelles Institute of Soclology, 1975.

E. Small Bus1nes a hdministration

1. Crimes Against Small Buslnesses: A Report of the Smal1 Business hdministration Transmitted to the Select Committee on Small Bustness, U.S. Senate, 1969, Senate Doc. No. 91-14.

g. U.S. Department of Comerce

1. Federal Government Sources on Crimes Against Business, Domestic and International Business Administration, 1977.

2. Crimes Agalnst Buglness, Seminar Proceedings.

- Cincianati, Ohio, September 25, 1975

- Los Angeles, Califoraia, February 5, 1976

- Fhoenix, Arizona, April 23, 1976

- New York, New York, September 14, 1976

3. Crimes Against Business: The Cost of Security, Staff Study, May 1978 ,

4. Crime in Servlce Industries, September 1977.

5. Crime in Retalling, August 1975.

6. The Cost of Crimes Against Business, January 1976 .

7. Federal Goverment Sources on Crimes Against Business, 1977.

i. Stanford Research Institute

1. Business Countermeasures to Crime Losses, Business Intelligence Program, Datalog Flle 75-34, June 1976. 
(Note: We were unable to abtain this full report due to Its proprietary nature)

1. Center for Comparative Criminology

1. Publications of the School of Criminology,

Universite de Montreal, April 1977.

j. U.S. Department of Justice (Law Enforcement Assistance Administration)

1. Harry A. Scarr, Patterns of Burglary, February 1972.

2. Carl E. Pope, Crime-Specific Analysis, An Empirical

Examination of Burglary offender Characteristics, Analytic Report No. 11, 1977.

\subsection{Comments on the Usefulness of Analogous Activities Data}

Our research Indicates that the current state of the data sources For theit losses does not allow for accurate identification of Invariant quantitles across different studies. The Conmerce Department highlights this sftuation fa its most recent business crime loss report, referenced In the preceding section:

The most serious difficulty associated with analyzing the impact of crimes against business continues to be the sparseness or sporadic nature of the data avallable. Figures are seldom based on comparable definitions or time perlods, and many data gaps exist. This drawback was highlighted in the 1968 report of the President's Commission on Law Enforcement and Administration of Justice, which stated: 
The only comprehensive study of the cost of crime in this country was made by the Wickersham Commission in 1931.... The lack of knowledge about which the Wickersham jommission complained 30 years ago is alrost as great today.

Although many of the recommendations of this Commission have since been adopted, tacluding the expansion of data gathering activities, there 13 still no comprehensive source for Information about crimes against business property.

Al though data sources may be internally consistent, comparisons among sources - even within the same ladustry - are suspect. The banking industry exemplifies this problem, as shown in the following table:

\begin{tabular}{lcr} 
Data Source & $\begin{array}{c}1976 \text { Total } \\
\text { Robbery and Burglary }\end{array}$ & $\begin{array}{c}1978 \text { Fraud and } \\
\text { Embezzlement }\end{array}$ \\
\cline { 2 - 3 } & & \\
SRI & $\$ 73,900,000$ & $\$ 368,300,000$ \\
ABA & $22,300,000$ & $88,000,000$ \\
Commerce & $27,300,000$ & $206,000,000$
\end{tabular}

It appears the data does not allow for consistent comparisons of theft losses across industries, at least ising published data sources.

In addition to difficulties comparing data actoss industries, it is necessary to be very careful in using data on otner indus tes to draw conclusions about theft of special nuclear material. The pocential of this material for use in military or terrorist activities means that there are potential adversaries, such as foreign nationalists or terrorists, that are almost unknown in other industries. 
PART III

DESCRIPTION OF METHODOLOGY 
Section 2.0 discussed the procedure used to characterize potential adversaries of kMS Systems in this study. In particular, attributes are used to describe adversaries and ellcit prcbabllity fuformation from experts, This information is then used to calculate bounds on the probabilities of adversary archetypes.

The prelininary adversary attributes defined in Figures 2.1 and 2.2 were developed by Woodward-Clyde Consultants based on discussions over a six-month period at several meetings inyolving hawrence Livermore Laboratory and subcontractor personnel. It is anticipated that these attributes will be refined in the future through further discussions involving a wlder range of experts ou adversary behavior.

The preliminary archetype definitions shown 1 in Flgure 2.3 were also developed by Woodward-Clyde Consultants based on discussions with Lawrence Liveraore Laboratory and subcontractor personnel. It is anticlpated that these defialtions will also be refined further in the future.

The archetypes, for which verbal definitions were given in Figure 2.3, can be more explicitly defined as collections of the 512 different types of adversaries defined by the various possible combinations of attribute levels in Figure 2.2. 
To convententiy represent the archetype definttions, a spectal coding procedure was developed, as shown in Pigure 4.1. Bach of the elght entries in the parentheses refers to one of the efght attributes defined in Figure 2.1, in the same order as given there. Thus, the first entry refers to the motivation attribute, the second entry to the MS System information attribute, and so forth. If an entry is a number different than zero, it represents the attribute level with that number, as given in Figure 2.2. This, an adversary coded as $(3,1,1,1,1,2,1)$ is one whose motivatios is extortion, and who has high levels of kMS gystem information and technical information, low consequence Information, high levels of processing capability and general resources, is risk-avoiding for hinself, but is risk-seeking for others.

If an entry is zero, it fudicates no restriction on that particular attribute, and so the code refers to a collection of some of the 512 possible adversaries. For example, the code $(3,0,1,0,0,0,0)$ represents all adversartes who have extortion as a motivation and a high degree of technical information.

The first step of the procesq used to determine archetype ciefinition was in identify those archeiypes that are impossible or extremely unlikely. These are defined both verbally and by code in Figure 4.2 .

After removing the adversary descriptions excluded by the rules in Figure 4.2 , the adversary archetypes are a collectively exhaustive and mutually exclusive set over the remaining adversary descriptions. The coded description of the archetypes is given in Figure 4.3 


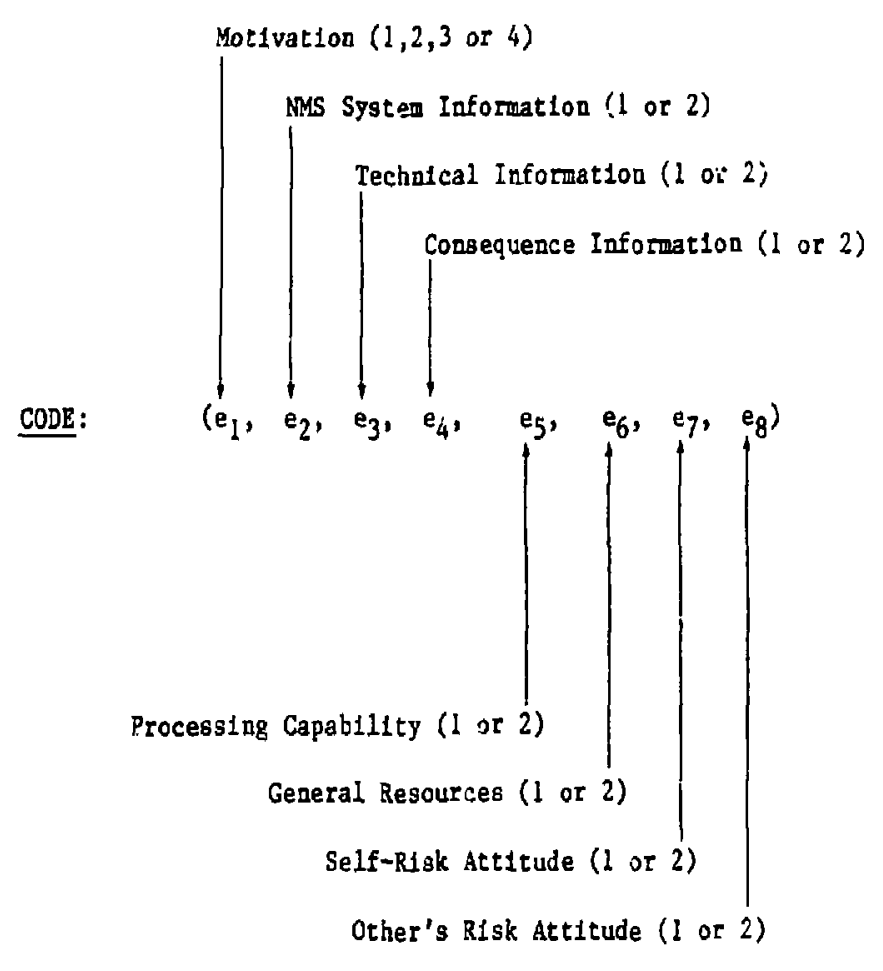

1. Entries in parentheses are attribute levels as defined in FIgure 2.2

or

2. If an entry is zero, the code represents no restriction on the level of that attribute. 
A. If an auversary has a low level of technical information about the object of diversion, he is not likely to have a high tapability for processing.

Code: $(0,0,2,0,1,0,0,0)$

B. For nongymbolic diversion, both a low-level knowledge of SMS System and a low technical level produce an unlikely adversary.

Code: $(2,2,2,0,0,0,0,0)+(3,2,2,0,0,0,0,0)+(4,2,2,0,0,0,0,0)$

C. Adversaries who seek a weapon are, by definition, not risk averse when 1 t comes to others.

Code: $(4,0,0,0,0,0,0,2)$

D. Adversaries who seek a weapon must have high technical information and processing capability.

Cade: $(4,0,0,0,2,0,0,0)$

E. If an adversary has a high level of Information about MMS System and technical aspects, and has high processing capability and resources, he is not likely to have a jow level of knowledge about consequences.

Code: $(0,1,1,2,1,1,0,0)$

F. Extortionists are likely to have a high consequence knov!ledge. Code: $(3,0,0,2,0,0,0,0)$

Notes:

1. Any of the 512 possible different types of adversaries that are included in one or more of the exclusion rules above are assumed to have zero probability of existing.

2. A total of 290 different types of adversaries are excluded by these rules.

F1gure 4.2 EXCLUSION RULES FOR IMPOSSIELE OR EXTREMELY UNLIKELY ADVERSARY DESCRIPTIONS 
1. Uninformed Outsider

2. Princinled Outsider

3a. Disgruntled Employee

3b. Disgruntled Imployees

4. Principled Executive

5a. Ccopetent Outsider

5b. Coonetent Out.61der Group

6a. Opportunistic Employet

6b. Opportunistic Employees

7. Hgh-Level Embezzling Group

8. Embazzling Executive

9. Terro:ist Grcup or Foreign Nationa: Group

10. Ierrorist Individual

11. Insider Terrorist Group

12. Instder Terrorist Individual

13. Outsider Extortionist Group

14. intoide Expert

15. Extorting Euployee

16. Extorting Fxecutive
$(1,2,2,0,0,0,0,0)$

$(1,2,1,0,0,0,0,0)$

$(1,1,2,0,0,2,0,0)$

$(1,1,2,0,0,1,0,0)$

$(1,1,1,0,0,0,0,0)$

$(2,2,1,0,0,2,0,0)$

$(2,2,1,0,0,1,0,0)$

$(2,1,2,0,0,2,0,0)$

$(2,1,2,0,0,1,0,0)$

$(2,1,1,0,0,1,0,0)$

$(2,1,1,0,0,2,0,0)$

$(4,2,1,2,1,1,0,0)$

$(4,2,1,0,1,2,0,0)$

$(4,1,1,0,1,1,0,0)$

$(4,1,1,0,1,2,0,0)$

$(3,2,1,0,0,1,0,0)$

$(3,2,1,0,0,2,0,0)$

$(3,1,2,0,0,0,0,0)$

$(3,1,1,0,0,0,0,0)$

\section{Notes:}

1. Verbai deifinitions of the archetypes are given in Figure 2.3, PP. $10-11$.

2. Note that attributes 4 (Consequence Information), 7 (Se1f-Risk Attitude), and 8 (0ther's-Risk Attiture) do not enter into the archetype definttions.

Figure 4.3 CODED DESCRIPTION OF ARCHETYPES 
UTILIZATION OR JUDGMENTAL INEORMATION

ABOUT ADVERSARIES

With the attribute levels shown in Pigure 2.2, there are 512 different possible adversaries. Thus, to quantify completely an expert's judgments about the relative likelihoods that an NMS System adversary would have varlous characteristics, it would be necessary to collect 512 different probability judgments. As discussed in Section 2.0, this appears to be difficult to do. Therefore, nineteen adversary archetypes were defined to characterize the range of possible theft attempts that might be made against an NMS System, and we developed a procedure to infer bounds on the probabilities of these archetypes from partial probability information elicited from adversary experts about the various attributes.

This section discusses the theoretical basis for using partial information about adversary characteristics, as well as a computer program to implement this theory. The motivation for using partial 1nformation to bound archetype probabilities was the expectation that a relatively small amount of information would lead to tight bounds on the archetype probabilities. In this case the derived (tightly bounded) archetype probabilities could be used as inputs to the WMS System model being developed by Lawrence Liverwore Laboratory. 


\subsection{Theoretical Basts}

The presentation in this section assumes the attributes, exclusion rules, and archetypes defined earlier* are being used. The mathematicil notation used In Section 4.0 (see Figure 4.1) to represent different adversaries will also be used here.

Wur elfcitation procedures allow in expert to provide numerical values or upper or lower bounds for any of the followlag types of judgmental probabil1:1es:

i. Marginal probabilities for any adversary attribute,

11. Conditional probabilities for any single attribute, given fnformation about the other attributes, and

111. Comparison of the magnitude of the probabilities of any two specifled strer:ary deccilptions.

For either $i$ or 11 above, specific numerical values may be specified for the probabilities, or bounds (either upper or lover) may be given.

\subsubsection{Formulation of Bounding Problem}

In this section the problem of bounding the archetype probabilfties using the three types of partial probability information discussed above 1s shown to be a linear program [2]. This is advantageous, since computer programs exist to solve Inear programs very efficiently.

*Modifications to these can be easily made. 
For notational convenfence let $\mathrm{T}$ represent the set of all 512 different adversary descriptions and let $t$ represent a specific element of ז. Further, let $A_{1}, A_{2}, \ldots, A_{n}$ represent the collections of points in $T$ in each of the $n$ archetypes and $E_{1}, E_{2}, \ldots, E_{\text {II }}$ represent the collections of points in $I$ in each of the $m$ exclusion tules. (The $E_{1}$ 's and $A_{i}$ 's are defincd respectively in Figures 4.2 and 4.3.) Further, let $P_{t}$ represent the probability of $t$, and $P(A)$ represent the probability of event $A$. Then, upper and lower bounds on the probability $P\left(A_{1}\right)$ of archetype $A_{1}$ can be found by solving the following two optimization problews:

\section{Problem 1: Upper Bound}

$$
\underset{\left[p_{t}, t \in T\right]}{\operatorname{maximize}}\left\{\sum_{t \in A_{1}} p_{t}\right\}
$$

subject to

$$
p_{t}=0, \quad \quad t \varepsilon E_{j} ; j=1,2, \ldots, \pi
$$

forntraints imposed by

$$
\text { probability assessments - discussed } 2 \pi
$$

$$
\text { Section 5.1.2\} }
$$

$$
\sum_{t \in I} p_{t}=1
$$

$P_{t} \geq 0$,

$t \varepsilon T$ 
The sumation in (5.1a) is the probability of archecype $A_{1}$. The upper bound is to be found for this, subject to the constralnts placed on it by the exclusion rules and the assessed probabilities. Since any $p_{t}$ must be non-negative, $(5.1 b)$ is equivalent to requiring that all $p_{t}$ covered by an exclusion rule must be zero. Equation (5.1d) expresses the fact that the sum of the probabilities over all possible adversaries wust add to one,

\section{Problem II: Lower Bound}

This problem is the same as Problem I, except that now the smallest possible value of each archetype is to be found subject to the various constraints placed on it.

$$
\underset{\left[p_{t}, t \in T\right]}{\operatorname{minimize}]}\left\{\left\{\sum_{t \in A_{1}} p_{t}\right\}\right.
$$

subject to

$$
P_{t}=0, \quad t_{E} E_{j} ; j=1,2, \ldots, m
$$

\section{\{constraints imposed by}

$$
\text { probabilicy assessmenis - discussed in }
$$
Section 5.1.2\}

$$
\sum_{t \in T} p_{t}=1
$$

$$
P_{t} \geq 0, \quad \quad t \in T
$$

Since there are nineteen archetypes, it is necessary to solve thirtyeight optimization problems to deternine upper and lower bounds for all 
archetype probabilities. If probability ellcltations are restricted to the three types discussed in Section 5.1, then the optemization problems are linear prograns, as shown in the following section.

\subsubsection{Formulatien of Constraiats}

For notational convenience let $k_{1 j}$ represent all elements of $T$ such that $e_{1}=f$, using the notation of Figure 4.1. That 1s, $K_{1 j}=(0,0, \ldots, 0, j, 0, \ldots, 0)$, where the only non-zero element in the vector is the $1^{\text {th }}$. Then, an assessed margtnal prcbability, as discussed In Item 1 of Section 5.1, imposes one of the following constratats:

$$
\begin{aligned}
& \sum_{t \in \mathbb{R}} p_{t j} \leq p, \\
& \sum_{t \in \mathbb{R}_{1 j}} p_{t}=p, \text { or } \\
& \sum_{t \in \mathbb{K}_{i j}} p_{t} \geq p,
\end{aligned}
$$

where $p$ is the assessed uarginal probability that attribute i is equal to j. Here (5.3a) corresponds to the case where the expert gives an upper bound on the probability, (5.3b) corresponds to the case where he gives a specific numerical value for the probability, and (5.3c) corresponds to the case where he gives a lower bound on the probability.

For notational convenience let $\overrightarrow{\mathrm{K}}_{1}$ represent a specified collection of levels for all attributes except the $1^{\text {th }}$. Thus, for example, $\bar{k}_{2}$ might represent all levels of attributes $1,3,4,5,6,7$, and 8 such that attribute 1 (Motivation) is either 1 or 2 (Symbolic or Money), attribute 2 (NSS System Information) is elther 1 or 2 (High or Low), and attributes 4 through 8 are all 1 . The conditional probability 
that the $1^{\text {th }}$ attribute equaly $k_{i}$ given that an adversary is in $\overline{\mathrm{R}}_{i}$ will be written $P\left(k_{1} \mid \vec{k}_{i}\right)$; further, $\left(k_{1}, \vec{k}_{1}\right)$ will symbolize all elements in I such that the $1^{\text {th }}$ attribute equals $k_{1}$ atd $\bar{k}_{1}$ is true.

Using this notation an assessed conditional probability, as disclissed In Irem 11 of Section 5.1, imposes one of the following constralnts:

$$
\begin{aligned}
& P\left(k_{1} \mid R_{1}\right) \leq P^{\prime}, \\
& P\left(k_{1} \mid \vec{k}_{1}\right)=P^{\prime}, \text { or } \\
& P\left(k_{1} \mid R_{1}\right) \geq P^{\prime},
\end{aligned}
$$

where $p^{\prime}$ is the assessed conditiunal probability that the $1^{\text {th }}$ attribute equals $k_{f}$ given $R_{i}$ is true. Here (5.4a) applies when an upper bound is given, (5.4b) when a spectic numertcal value is given, and (5.4c) when a lower bound is given.

From the defintion of conditional probability

$$
P\left(k_{1} \mid \bar{k}_{1}\right)=\frac{P\left(k_{1}, \bar{n}_{1}\right)}{P\left(\bar{R}_{1}\right)} .
$$

But

$$
P\left(k_{1}, \vec{k}_{1}\right)=\sum_{t \in\left(k_{i}, i_{1}\right)} P_{t}
$$


and

$$
P\left(R_{1}\right)=\sum_{t_{\varepsilon} \bar{K}_{I}} p_{t} \cdot
$$

Substituting (5.5) Into (5.4) and rearranglog terms results in

$$
\begin{aligned}
& \sum_{\left(k_{i}, \bar{k}_{1}\right)} p_{t}-p^{\prime} \sum_{t_{\varepsilon} \bar{K}_{1}} p_{t} \leq 0, \\
& \sum \mathrm{p}_{\mathrm{t}}-\mathrm{p}^{\prime} \sum \mathrm{p}_{\mathrm{t}}=0 \text {, or } \\
& t_{\varepsilon}\left(k_{1}, \bar{k}_{1}\right) \quad t_{\varepsilon} \overline{\mathrm{K}}_{1} \\
& \sum_{t_{\varepsilon}\left(\mathrm{k}_{1}, \overline{\mathrm{R}}_{\mathrm{f}}\right)} \mathrm{p}_{t}-\mathrm{p}^{\prime} \sum_{\mathrm{t}_{\varepsilon} \overline{\mathrm{R}}_{\mathrm{f}}} \mathrm{p}_{\mathrm{t}} \geq 0 .
\end{aligned}
$$

Finally, the comparison of any two probabilities, as discussed in Item 11i of Section 5.1, 1mposes one of the following constraints:

$$
\begin{aligned}
& \mathrm{P}_{\mathrm{t}_{1}} \leq \mathrm{P}_{\mathrm{t}_{2}}, \\
& \mathrm{p}_{\mathrm{t}_{1}}=\mathrm{p}_{\mathrm{t}_{2}} \text {, or } \\
& \mathrm{p}_{\mathrm{t}_{1}} \geq \mathrm{p}_{\mathrm{t}_{2}},
\end{aligned}
$$

where $t_{1}$ and $t_{2}$ are two differenc elements of $T$. Here (5.6a) applies for an upper bound, (5.6b) for a specific numerical value, and (5.6c) for a lower bound, (The ability to impose constraints of this type is included in the computer Implementation discussed in the next section. However, because of the laborlousness of assessing informatiun of this type, the elicttation procedure we developed does not use constraints of this form.) 
Thus, to determine how the assessed probabilities restrict the possible values of the archetype probabilities, the appropriate constraints from among (5.3), (5.6), and (5.7) are substituted 1ato (5.1c) and (5.2c) and the resulting optinization problems solved. (Note that there might be several different constraidts of each of the three types depending on the information elicited.) Since (5.3), (5.6), and (5.7) are ali linear constraints, the resulting optinlzation problems are linear programs. The computer program developed to solve this linear program is discussed in the following section.

\subsection{Compiter Implementation}

Solution of (5.1) and (5.2) is conceptually straightforward since there are programs available on most computer systems that will solve linear prograns much larger than the ones of interest here. However, manually entering the data for the optinlation $z=2$ tiens world be an extremely tedious task. There are 512 different $p_{t}^{\prime} s$ and, depending on the assessed probabillty data, perhaps several dozen constraints. EnterIng the necessary Information, particularly if data is assessed for several different experts, would be time-consuming and subject to error.

To avoid these difficulties a preprocessor program was kritten in Fortran to take Information about assessed probab111ties and set up data representing the approprlate constraint equations. This preprocessor was written to work with the linear program solution package MPS, which is part of the IBM Yathematical Programing System, avallable on most IBM computer systems. The entire computer procedure to take ellcited data and generate bounds on archetype probabllities has been implemented as an interactive program on the Michfgan Terminal System (MTS) at the University of Michigan. A User's Guide giving instruccions on how to use this is included in Appendix $A 3$. Specific instructions on how to prepare responses to the questionnaire in Appendix A2 for input to the computer program are contained in Appendix A4. 
To briefly sumarize the use or the computer program, data is entered using the coded representation shown in Figure 4.1. Thus, for example, 10000000 G .3 means:

the probability that Motfvation is Symbolic is greater than . 3 .

Similarly, 20000000L30000000 means:

the probability that Motivation is Money is less than the probability that Motivation is Extortion.

Conditional probabilities are entered using a slight variation on this coding scheme. For example, $P G=1 G 1=4 G .7$ means:

the probability that attribute 6 (General Resources) is High, given that attribute 1 (Motivation) is Weapon, must be greater than .7.

The preprocessor is interactive and provides extensive prompting to the user. However, the underly!ng programs, which are documented in Appendix A5, are fairly complex. It is necessary to handle and surt a number of large data files which are either created by the preprocessor or permanently stored for use by the program. These manipulations, of necessity, use system commands that are specific to tine Michigan Terminc1 System. Although it would be possible to write sizilar programs to carry out the required tasks on most large computer sysieus, the current procedures cannot be moved easily from the Michigan system to another system. 
The procedure for eliciting judgmental information concerning the relative 1ikellhoors of various potential adversarles is buflt around the Brlefing Document (Included as Appendix Al to this report) and the Questionalre on Adversary Characteristicg (Included as Appenaix A2).

The Briffing Document furnlshes general background 1nformation on other theft situations that are analogous in some way to theft from a Nuclear Material Safeguerds System. It is written as a relatively neutral presentation of facts; however, it will almost certainly impress the reader with the fact chat in many Industr.'es theft by insiders is a significantly more serious naoblac than theft by outsideis.

The questionnalre is seli-explanatory, but it is not desinned to be self-administered. Someone famillar with the subject matter and who understands how the answers will be used should be present to answer questions raised by the expert fliling out the questionuaire. Furthermore, in keeping with standard practice for the ellctication of judgmental probabilities, the expert should be closely examined to determine the reasons for the answers given, and to find inconsistencies in the respones.

The questionnaire was used to elicit judgments frcm three Lawrence livermore Laboratory experts on adversaries. The results of this elficitation are discussed Ir Section 7.0 . 
This section repozts the results of assessing judgmental probability information from three experts on adversary behavior at Lawrence Lfvermore Laboratory. The elfcitation process resulted in probability information about adversaries, and, in addition, the experts made a number of suggestions regarding ways to improve the elfcitation procesis. Both the suggested changes in the elicltation process and the actual assessment results are discussed below.

\subsection{Recommended Improvement3 to Elicitation PLocess}

The experts made a number of recommendations for clarifying the instructions for the questionnalre which have been lacorporated into the questionnaire in Append1x A2. The most significant of these were to Insiude in the introduction a more careful definition of the types of thefts of nuclear materiais that were to be considered, and to include a more complete explanatioil of the purpose of the attributes.

The origial questionnafre asked direccly for probabilfties, but the experts felt that questions shoula be asked in tarns of relative likelihocds rather than probibiittles, since they found it more natural to think in terms c $\dot{c}$ rrlative 1 figelfhoods.

The experts also felt that the number of qucsticrs relating to conditional probabilities (Sections 4.0 through 7.0 ) should be cut. For example, in Question 4.0 the original questionnaire asked for probabilities 
conditional on low, as well as high, levels of MMS System Information, Technical Information, and General Resources. The experts felt that too many questions were belog asked, and that it would be preferable to cut down the number of questions so there was time to answer the ones that remained more carefully.

Finally, the experts felt that an additional section should be added which directly asked for archetype probahilities. Although a purpose of the methodology presented here is to avold having to asses? archetype probabilities directly, the experts felt 1 would be useful to assess these for comparison against the archetype probabilities indirectly determined from information on the attributes. Section 8.0 was added to the questionnalre In Appendix A2 to directly assess probabilities of archetypes.

The experts found that the attribute definitions were meaningful and that they could answer the questions. One expert noted that he found it difficult to think abut the marginal probability questions in Section 3.0 of the questionnaire. He found it more natural to consider a more complete description of an adversary, fucluding levels for several attributes. With hard thought, hovever, he could answer these questlons.

The experts felt that the Briefling Document, Included In Append1x Al, contained useful background matertal with which they, and probably other experts on adversary behavior, were not familiar.

The next section discusses the results of the elicitation. 


\subsection{Elicitation Results}

Figures 7.1 and 7.2 show the results of responses produced hy thrze experts - A, B, and C - to the questionnaire. Figure 7.1 shows their judgments on the relative likelihoods of the levels of the Motivation, MMS System Information, Technical Information, and General Resources attributes. Note that these differ significantly from one expert to another. Thus A judges money motivation to be 10 tines as 11 kely as symbolic, whereas $B$ judges symbolic motivation to be 10 times as likely as money.

Figure 7.2 shows responses to Questions $4.0,5.0,6.0$, and 7.0 of the questionnaire. The responses of $A$ and $B$ to Question 4 indicate that these experts regard knowledge about: a high level of NMS Systen Information, a high level of Technical Information, and a high level of General Resources to be equivalent in terms of adjusting the relative likelihoods of the four motivations. Expert $C$ has chosen to use the qualitative option when he judges, for example, that knowing an adversary has a high level of MMSS 1nformation will make the likelthood of symbolic motivation greater ("G") than without this information.

\subsection{Results: Probabilicy Bounds}

The judgments shown in Figures 7.1 and 7.2 were coded for entry into the preprocessing computer program (see Appendix $\$ 4$ for the coded representation).

Using all the information provided by each expert resulted in the deternination that each one was inconsistent in his own statements. That 1s, the judgments provided by a particular expert produce a set of constraints on the relevant probabilities that are not satisfied by any possible set of probabilities. 


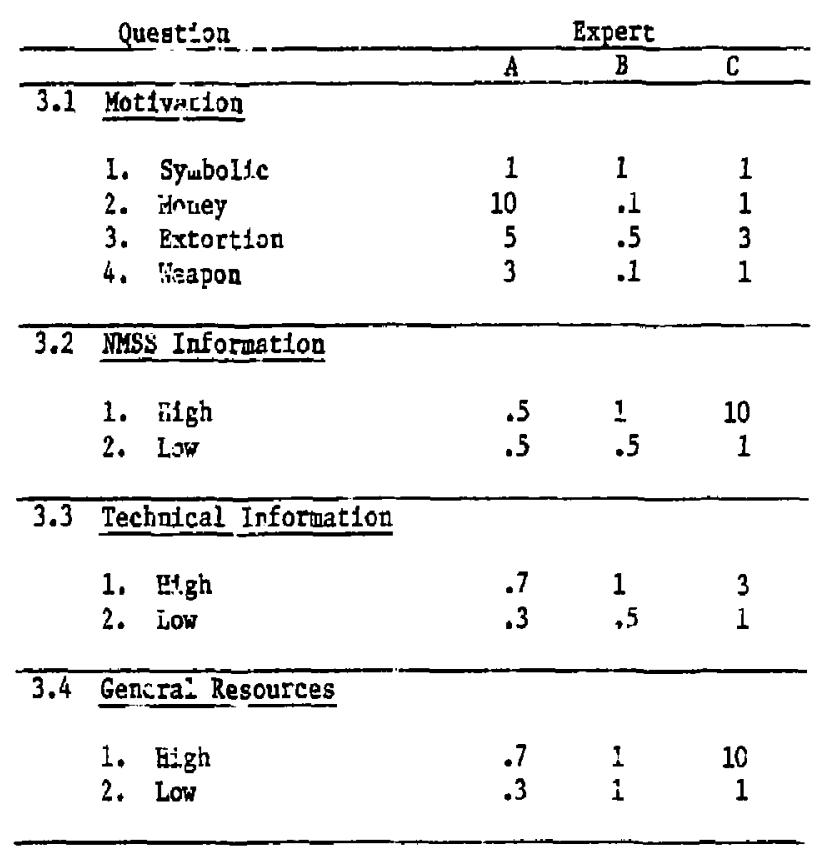

Figur: 7.1 MARGINiL RELATIVE LIKELIHUODS (RESPONSTS OF TRRES EXPERTS TO QUESTIONNAIRE) 
Question

\subsection{Motivation}

\section{Symbolic \\ 2. Money \\ 3. Extortion \\ 4. Weapon}

5.0 NMS System Information

1. High

2. Low

$\stackrel{\mathbb{N}}{\sim}$

6.0 Technical Information

1. H1gh

2. Low

7.0 General Resources

1. High

\begin{tabular}{|c|c|c|}
\hline \multicolumn{3}{|c|}{ High } \\
\hline NMSS & Informa & ton \\
\hline A & B & $\mathrm{C}$ \\
\hline 1 & I & G \\
\hline 10 & 1 & $\mathbf{L}$ \\
\hline 5 & 1 & $\mathbf{L}$ \\
\hline 2 & 1 & $\mathbf{L}$ \\
\hline
\end{tabular}

\begin{tabular}{rrr}
\multicolumn{4}{c}{ HIgh } \\
Technical & Informat \\
\hline A & B & C \\
\hline 1 & 1 & G \\
10 & 1 & L \\
5 & 1 & L \\
2 & 1 & G
\end{tabular}

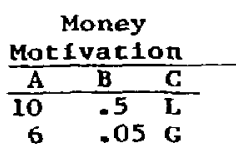

Weapon

\section{High Technical}

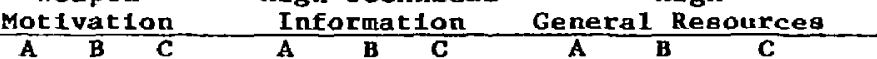

\begin{tabular}{ccc} 
A & B & C \\
\hline 2 & 1 & G
\end{tabular}

\begin{tabular}{lll} 
A & B & C \\
\hline 1 & 1 & G
\end{tabular}

\begin{tabular}{ccc}
$A$ & B & C \\
\hline 10 & 1 & G \\
0 & 1 & L
\end{tabular}

Money

Weapon

High NMS

$$
\text { L }
$$

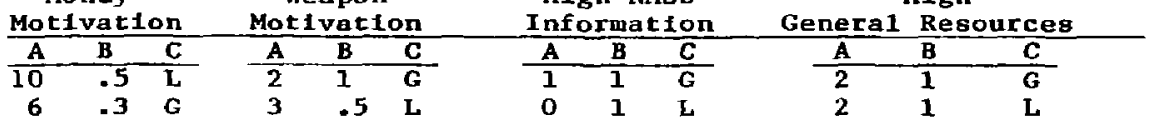

Money
tivation

Weapon High NMSS

High

Motivation . Motivation Information Technical Inforroation

\begin{tabular}{|c|c|c|c|c|c|c|c|c|c|c|c|}
\hline$\overline{\mathbf{A}}$ & B & $\bar{C}$ & $\mathbf{A}$ & B & $\bar{C}$ & $\overrightarrow{\mathbf{A}}$ & $\mathrm{B}$ & $\mathbf{C}$ & $\bar{A}$ & $\mathbf{B}$ & C \\
\hline 5 & 1 & $\mathrm{E}$ & 2 & $\overline{2}$ & $G$ & 4 & 1 & $\bar{G}$ & 4 & 1 & $G$ \\
\hline 1 & . 1 & $\mathbf{E}$ & 0 & $\therefore$ & I & 0 & 1 & L & 3 & 1 & $\mathbf{L}$ \\
\hline
\end{tabular}

Figure 7.2 COND I TIONAL RELATIVE LIKELIHOODS (RESPONSES OF THREE EXPERTS - A, B, AND C TO QUESTIONNAIRE) 
For experts $A$ and $B$, this 1nfeasibility exists even wher their fudgments about the conditional 11kelihoods of Questions 4.0,5.0, and 6.0 were 1gnored. For expert $C$, hcwever, when the conditional likellhoods of Questions 5.0,6.0, and 7.0 were not considered, but those of Question 4.0 were considered, archerype probability bounds resulted as shown in Figure 7.3. Also shown in this figure are the bounds resulting from the consideration of experts $A$ and $B$ 's judgments about marginal likelihoods only (e.g., the responses to questions $3.1,3.2$, 3.3, and 3.4).

These results lead us to soire preliminary conclusions about the elfcitation process:

a. It appear to be extremely difficult to avold a combiration of likellhood judgments that lead to an inconsistent set of probabilities. For this reasja, responses to Questions 4.0, $5.0,6.0$, and 7.0 should be used only if the expert is completely confident in his interpretation and his responses.

b. Ever though experts $A$ and $B$ have extremely different judgments con. .nntig the reiat1ve 11kel1hood of symbolic to money motipation, the resulting differances in upper bounds on the archetype probabilities are not as severe.

c. Further development of the questionnalre should concentrace on finding ways to elfcit conditional likelihoods (and/or comparison of likelihoods) in such a way as to avold infeasibilities while still incorporating meaningful expert judgment. One possible cause of infeasibilities is that the experts may be Informally excluding certain combinations of attribute values in the1t heads when they answer the questlonnaire. Since there 
Using Judgments of Experts

\begin{tabular}{|c|c|c|c|c|c|c|}
\hline \multirow{2}{*}{$\begin{array}{c}\text { Archetype } \\
\text { Number }\end{array}$} & \multicolumn{2}{|c|}{$A^{*}$} & \multicolumn{2}{|c|}{ B* } & \multicolumn{2}{|c|}{$C^{* *}$} \\
\hline & liax. & Mto. & Max. & Min. & Mox. & Min. \\
\hline 1 & .0526 & 0 & .3333 & 0 & $.015 i 5$ & 0 \\
\hline 2 & .0526 & 0 & .3333 & 0 & .01515 & 0 \\
\hline $3 \mathrm{~A}$ & .0526 & 0 & .33 .33 & 0 & $.04 i 6 i$ & 0 \\
\hline $3 B$ & $.05 \% 6$ & 0 & .3333 & $u$ & .04167 & 0 \\
\hline 4 & .0526 & 0 & .4608 & 0 & .1667 & .10987 \\
\hline $5 \mathrm{~A}$ & .3 & 0 & .0588 & 0 & .01515 & 0 \\
\hline $5 B$ & .5 & $\mathrm{C}$ & .0588 & 0 & .04545 & 0 \\
\hline $6 \mathrm{~A}$ & j & 0 & .0588 & 0 & .01515 & 0 \\
\hline $6 \mathrm{~B}$ & .3 & 0 & .0588 & 0 & i.i & .02652 \\
\hline 7 & $.25<0^{\circ}$ & 0 & .0388 & 0 & .10987 & 0 \\
\hline 8 & .2526 & 0 & .0588 & 0 & .01515 & 0 \\
\hline 9 & .1579. & 0 & .0589 & 0 & .0303 & 0 \\
\hline $1^{n}$ & .1579 & 0 & .0589 & 0 & .0303 & 0 \\
\hline 11 & .1575 & 0 & .0589 & 0 & .1066 & .06056 \\
\hline 12 & .1579 & 0 & .0589 & 0 & .07575 & 0 \\
\hline 13 &.$\approx 632$ & 0 & .2941 & 0 & .07575 & 0 \\
\hline 14 & .2632 & C & .2341 & 0 & .04545 & 0 \\
\hline 15 & .2632 & 0 & .2941 & 0 & .20833 & .12500 \\
\hline 16 & .2632 & 0 & .2941 & $c$ & .32955 & .21593 \\
\hline
\end{tabular}

* Using tesponses to questluns $3.1,3.2,3.3,3.4$ only

**Using reeponsus to questions $3.1,3.2,3.3,3.4$, and 4.0

Figu= 7.3 BOUNDS ON ARCAETYPE PROBABILITIES 
are foral exclusion rules built inco the algorithm that calculates bounds on archetype probabilities, it may be that the exclusions are being double-counted.

For comparison, the directly assessed archetype probabilities (1.e., the answers to Question 8.0) are presented in Figure 7.4 . 
Expert

\begin{tabular}{|c|c|c|c|}
\hline Archetype & A & B & $C$ \\
\hline 1 & .026 & .028 & .023 \\
\hline 2 & .026 & .028 & .006 \\
\hline $3 a$ & .052 & .285 & .023 \\
\hline $3 b$ & .042 & .057 & .023 \\
\hline 4 & .016 & .142 & .188 \\
\hline $5 a$ & .052 & .0003 & .023 \\
\hline $5 b$ & .104 & .003 & .094 \\
\hline $6 a$ & .052 & .057 & .047 \\
\hline $6 \mathrm{~b}$ & .042 & .114 & .023 \\
\hline 7 & .104 & .028 & .117 \\
\hline 8 & .208 & .057 & .070 \\
\hline 9 & .078 & .011 & .070 \\
\hline 10 & .026 & .003 & .005 \\
\hline 11 & .026 & .003 & .001 \\
\hline 12 & .026 & .006 & .003 \\
\hline 13 & .026 & .014 & .141 \\
\hline 14 & .016 & .014 & .023 \\
\hline 15 & .052 & .142 & .047 \\
\hline 16 & .026 & .006 & .070 \\
\hline
\end{tabular}

Figure 7.4 DLRECTLY ASSESSED ARCHETYPE PROBABILITIES

(From Responses to Question 8.0 of

Questionnalre) 
The methodology described in this report was applied to the elicltation and analyeis of judgmental information from three experts. The queetioning procedure was luaningful to the experts, and the computer programs were able to analyze the information from the experts. The results were e1ther bounds on the archetype probabilities or 1adications of Inconststent responses.

Further development of the methodology would require that the adversary attributes, ex=lustor rules, and archetypes be refined. The current attributes, ruies, and archetypes have proven to be meaningful for preliminary analysis; however, varlous Individuals who have reviewed them have raised objections to some detalls, and have suggested some changes. Th1s discussion shculd be widened to include experts at the Nuclear Regulatory Commission and elsewhere so that a wider range of expertise can be utilized in arriving at a final set of attributes, exclusion rules, and archetrpes. 
Additional references relating specifically to the analysis of activities potentially analogous to Nuclear Material Safeguards Systems are included in section 3.2 .

1. P. deleon, B. Jink1ns, R. Kellen, and Krofcheck, "Attributes of Potential diversaries to U.S. Nuclear Programs," Santa Monica, Calffornia: The Rand Corporation, R-2225-SL, Decemijer $: 977$.

2. H.M. Wagner, Principles of Operations Research, 2nd edition, Englewood Cliffs, New Jersey: Prentice-Yal1, 1975.

3. N.R. Hagner, "A Survey of Threat Studies Related to the Nuclear Power Induetry," Livermore, California: Sandia Labcratorles, SAND77-8254, August 1977.

4. M. W1llich and T.B. Taylor, Nuclear Theft: Risks and Safeguards, Cambridge, Massachusetts: Ballinger, 1974. 


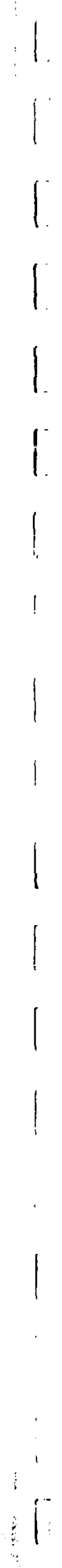

APPENDICES 
APPENDI: Al

BRIEFING DOCUMENT 
Brlefing Document for

QuesLionalte cn Adversary Characteriseics

Nuclear Material Safeguards Systems

Septenter 1978 


\subsection{INTRODUCTION}

Nuclear material is currently stored, used, reprocessed and transported between a relatively small number of sites, and an extremely limited nuber of attempts to divert material have been discovered and studied. Thus there is almost no directly relevant historical data on which to base statements about patential adversartes of Nuclear Material Safeguards (INE) Systens.

Bowever, situations that are analogous in some ways to nuclear material safeguarding are crmon ard are discussed below. It should be recognized that the available data on crimes against business are Iimited. Furthermore, while the situations examined have characteristics analogous to a Nuclear Material Safeguards System, they also have inportant differences.

\subsection{POTENTIALLY ANALOGOUS SITUATIONS}

Protection of bank assets. This is similar to nuclear materlals safeguarding in several ways: the assets are protected by toth physical and accounting safeguards; they art usually kept in a relatively large facility; government regulations cover the safeguarl's. However, there are differences between the NMS System and bank situations. Physical removal of material is not necessary in a bank, and nuciear waterial presents unique handling and storage problems for a divercier. Also, the genera. pubiic is more familiar with the operations of a bank than with those of a nuclear facility.

Air and motor cargo freight. This of ten involves high value assets with sjecial handling and storage problems. 
Phar aceutical manufacturing. This involves high-value material.

Ridrapping. Both people and high value assets have been stolen in attempts to obtain money or nonfinancial ends (such as release of political prisoners). In virtually all cases the security systems are e1ther nonexistent or less effective than those in a MMS System.

Terrorism. Slace our concern in this study is with theft of speciai nuclear material, we are not directly interested in terrorist sabotage actions against $\Sigma \mathbf{n}$ MSS System. However, terrorists might attempt a theft in order to obtain nuclear materfal for use in other terrorist activities.

\subsection{INTTRNAL VERSUS EXTERNAL THREATS}

In 1976 the Stanford Research Institute (SRI) complled loss statistics from the banking, alr freight and motor freight industries on internal versus external crimes (see Figure la.) For bankfng, Internal crime was defined as employee theft, embezzlement and fraud, while external crimes were robbery, burglary, latceny and extortion. For air and motor freight, internal losses were items reported as "shortages", while external losses were from hijacking, robbery, theft and pilferage. As Iigure la shows, losses from fnsiders exceed those from outsiders by a substantial margin in all three categories.

Other data sources support the contention that internal crine losses exced those due to outsiders. For example, a 1977 Anerican Bankers Association survey (see Figure $1 \mathrm{~b}$ ) showed that unrecovered losses due to employee dishonesty and mysterlous disappearances exceed those due to robbery and burglary by a factor of almost two. 
(a) SRI Study

\begin{tabular}{lrrr} 
Category & $\begin{array}{c}\text { Internal } \\
\text { Loss }\end{array}$ & $\begin{array}{c}\text { External } \\
\text { Loss }\end{array}$ & $\begin{array}{c}\text { Rat10 of } \\
\text { Internal to } \\
\text { External Losses }\end{array}$ \\
\hline Banking (FY 1974-75) & $\$ 368,391,000$ & $\$ 73,949,000$ & 4.98 \\
A1r Freight (FY 1973-74) & $9,354,000$ & $2,441,000$ & 3.83 \\
Motor Freight & $132,974,000$ & $17,721,000$ & 7.50 \\
\hline
\end{tabular}

Source: B. Parker, "Business: Victims of Crime," Security Management, March, 1977, p. 29.

(b) American Bankers Asbociation Survey

Losses per Bank during 1976

Category (thousands of \$)

Employee Dishonesty

$\left.\begin{array}{l}29.96 \\ 30.69\end{array}\right\} 60.65$

Mysterious Disappearance

$\left.\begin{array}{lr}\text { Burglary } & 7.15 \\ \text { Robbery } & 24.53\end{array}\right\} 31.68$

Source: American Bankers Association, Confidential Bank Insurance Survey, 1977, Figure 13.

Figure 1. INTERHAL VS. EXTERNAL LOSSES 
A 1977 Commerce Department review of crimes against business [1] using F.B.I. statistics showed that external bank losses (robbery, burglary, and larceny) were $\$ 27.3$ million per year, while fraud and embezzlement losses (after subtracting $\$ 50$ million [2] due to check fraud, i.e., writing bad checks, which has no direct nuclear analogy) totaled $\$ 156.3$ million.

That study also notes that "85 percent of thefts and p1lferage are traceabla to persons authorized to handle fretght." Similarly, 1t coments that for air cargo theft "76 percent of all [theft and pilferage] losses were [due to]...parzons authoriced lu be on the premises...Atmed robbery and hijackings were rare, comprising only one percent of thefts."

The Commerce Department estinates that 75 to 80 percent of inventory shortages in retail establishments are caused by employee theft [3] and that "the majorits of invantory losses [in hospitals] are caused by employee theft [1]."

A Rurns Security Institute survey of pharmaceutical manufacturers showed that aine manufacturers out of a total of 96 respondents listed employee theft as a major problem, while only one listed external theft as a major oroblem [4]. However, in a similar survey of electric utilities, the two-thirds of the 367 respondents who commented listed external theft as more prevalent than internal by a four-to-one margin [5].

\subsection{COMPUTER CRIME}

Aú SRI scudy reports that the average loss from a computer-aided embezzlement is $\$ 450,000$, compared with $\$ 19,000 \mathrm{f}$, $\mathrm{r}$ the average "manual" embezalewent [6]. Commerce Tepartment figures dlffer, however, showing 
the average loss from a manual embezzlement to be $\$ 100,000$ and estimating the average computer embezzlement to be ten times this amount [1].

Estimates by several sources indicate that between 80 and 90 percent of computer crime is aever detected. Furthermore, the Commerce Department estimates that for every five computer crimes detected, only one is reported [1].

\subsection{FACILITY SIZE VERSOS TYPE OF THEFT}

An American Bankers Association survey of bank losses [7] showed that employee dishonesty costs three times as much money as robberies for banks with more than $\$ 1$ billion in assets. However, banks with less than $\$ 25$ million in assets lost twice as much to robbery as to employee disiwnesty.

Total losses per dollar deposited also appear to be related to bank size, with larger banks having constderably lower ratios of loss" to-deposit than swal! banks.

\subsection{TERRORIST OR MILITARY-RELATED THEFT}

The discussion above focuses primarily on activities where monetary gain is the principal objective. There are aumerous reasons ocher than money for theft of nuclear materials. An important class of these might involve the same motivations that lead to terrorist activities of the type increasingly carried out around the world during the past two decades. Although data on these activities has not been included here, they should be kept in aind while answering the questionnalre. [This section was added to the briefing document after the elicitations reported in section 7.0 . 
Another Lawrence Livermore Laboratory subcontractor is currently studyIng these types of activities. When his work is completed, this section should be expanded.]

\subsection{CONCLUDING COMMENTS}

There are substantlal differences between nuclear material safeguards systemis and those designed to protect the various other lndustrles discussed above. However, there are also significant simflarities. Hopefuliy, the material presented above has pointed out these similarities in a manner that will be useful to you as you answer the accompanying questlonnaire. 
REFERENEES

1. D.S. Departmest of Commerce, Crimes Against Service Indugtries, Sept cmber, 1977.

2. Amer f́can Jankers issociutiun est1mate.

3. J.S. Dephrtmeut of wamnrce, The Costs of Crime Against Business, January, 1976.

4. Burns Sesurity inetitute, National Survey on Pharmaceuticd Munufecturing Security.

5. Burns Security Institute, Nafional Survey on Electric Utilities Secur1ty.

6. U.3. Departrent of Commerca, "Crimes Against Business," Conference Proceedings, February 3, $197 €$.

7. American Bankers Assoctation, Conitdential Bank Insurance Survey, 1977. 
1

1

1

1

1

1

1

APPENDIX A2

QUESTIONNAIRE



$i$

1

q 
Questionna1re on Adversary Characteristics

Nuclear Materlal Safeguards Systems

September 1978 


\subsection{INTRODUCTION}

This questionnaire w1ll ellcit your judgments about potent1al adversaries of Nuclear Material Safeguards (NMS) Sygtems. When answerting the questionnaire, you are to consider any attempts to divert special muclea: materdal ifom the nuclear fuel sycle with1n the United States. Special nur:lear material includes all mererials from which an explosive nuclear weapon could be constructed.

Posstble mottvations for theft of spectal nuclear matertal include (1) construction of a weapon, (11) extortion for such purposes as political gain or prisoner release, (11i) monetary gain through sale of the material or ransom for its return, and (1v) symbolic reasons, such as publicity for a cause or persoual revenge.

The elght attributes shown 1 Figure 1 have been defined to assist in describling NMS System advarsarles. Four possible levels have been defined for the "motivation" at:ribute and two possible levels for each of the other attributes. The defiutions of these are given in Figure 2 . Using this structure, any par:icular adversary caú be described by specifying levels for each of the elght attributes. Thus, for example, one possible adversary would haye symbolic motivation, high IMS j5stem technical and consequence laformation, high processing capability ani general resources, and a risk-oeeking attitude toward both himsalf and others. The questions you will consider below refer to these attribute levels, so gou should make certaic you understand these definitione.

The briefing document which accompanles this questionnalre contains a summary of research on theft situations that are analogous in sume ways to the theft of nuclear materlal from a Nuclear Material safeguards System. 


\subsection{GENERAL QUESTIONNAIRE NSSTRUCTIONS}

When answering the questions below, the following context should be assumed: an artempt so divert material has taken place, but its success or failure is ant knuwn. That is, you are asked to answer the questions for the potentinl adversaries who would actually attempt a theft. Putifns this another way, we wish to obtain your judgments about the relative likelthoods of various adversary characteristles, but we do not want your judgment of the absoiute likellbood that an attempt at theft w1l be made.

Note aiso that there are no correct or Incorwect answers to the questions. Since the history of attempts to steal nuclear material is ve:s 11 mited, we have no meaningful statistics on adversary characteristics. This questionalice provides a uniform procedure for eliciting information from experts on adversary behavior. The results will be analyzed by computer to determine the extent of agreenent or disagreement among various experts.

\subsection{QUESTIONS ABOUT INDIVIDUAL ATTRIBUTES}

In this section you are asked to give your best judgment of the IElative likelihoods that an adversary who attempts a theft will have various levels of the individual attributes. When answering a question for a particular attribute, you should make no assumptions about the levels of the other attributes. As an example, in question 3.1 you may feel that "weapon" is the least likely motivation, "extortion" is twice as likely as weapon, and that "symbolic" and "money" are equaliy 11 kely and each is six times as likely as weapon. In this case, you would answer Question 3.1 as follows: 
1. Symbolic 6

2. Money 6

3. Extortion 2

4. Weapon 1

As a check on your answers, you should verify that the various responses are consistent with each other. For example, the answers given above imply that money is three times as $11 \mathrm{kely}$ a motivation as extortion.

3.1 Motivation: What are the relative likelihoods that an actual adversary will have each of the following motivations?

1. Symbolic

2. Money

3. Extortion

4. Weapon

3.2 MS System Information: What are the relative likelihoods that an actual adversary will have the following information about the Nuclear Material Safeguards System:

1. High

2. Low

3.3 Technical Information: What are the relative 11kelihoods that an actual adversary will have the following levels of techntcal Information?

1. High

2. Low 
3.4 General Resources: What are the relative likelihoods that an actual adversary will have the following levels of general resources?
1. Eigh
2. LoW

4.0 QUESTIONS ABOUT MOTIVATION WITA ADDITIONAL INFORMATION KNOWN

The earlier question about the "Motivation" attribute (Question 3.1) asked you to give relative Iikelihoods without making any assumptions about the levels of the other attributew. In the question below, you will answer the same question, except now you are to assume some information is known about the levels of the other attributes. In $1 a^{\prime \prime-}$ ticular, please give your relative 11kelihoods for the different leve is of Motivation for each of the three cases (labeled a, b, and c) stoma In the chart below. If you cannot provide numerical answers, please Indicate whether the chances of a particular level are greater than (G), less than ( $L$ ) or equal to $(E)$, the corresponding chances in Question 3.1 .

As an example, in column "a" you are to assume the adversary has "high" NMS System information. If you believe an adversary with high NMS System Information is least likely to have money as a notivation, equally likely to have any of the otier three motivations, and that each of these motivations is three times as likely as the money motivation, then you would fill in column "a" as follows:

$\begin{array}{ll}\text { Symbolic } & 3 \\ \text { Money } & 1 \\ \text { Extortion } & 3 \\ \text { Weapon } & 3\end{array}$


If you are unable to dectide on relative likelihocds given this additional information but believe the chances the adversary's motivation is money are lessened by knowing he has high MSS System Lfformation from what they were without this information, whlle the chances of each of the other three motivations is increased, then you would ill in column "a" as follows:

$\begin{array}{ll}\text { Symbolic } & G \\ \text { Mouey } & \text { L } \\ \text { Extortion } & G \\ \text { Weapon } & G\end{array}$

Note that the answers in each of the three columns are separate, that is, in each column you are asked to assume different faformation is known.

\begin{tabular}{|c|c|c|c|}
\hline \multirow[b]{2}{*}{$\begin{array}{l}\text { Levels } \\
\text { of } \\
\text { Mctivation }\end{array}$} & \multicolumn{3}{|c|}{ Given the Adritional Iniormation that: } \\
\hline & $\begin{array}{l}\text { The Level of } \\
\text { NMSS Syst in In- } \\
\text { formation is Higi } \\
\text { (a) }\end{array}$ & $\begin{array}{c}\text { The Level of } \\
\text { Technical Information } \\
\text { is High } \\
\text { (b) }\end{array}$ & $\begin{array}{l}\text { The Level of } \\
\text { General Resources } \\
\text { 1s High } \\
\text { (c) }\end{array}$ \\
\hline :ymbolic & & & \\
\hline Money & & & \\
\hline Extortion & & & \\
\hline Weapon & & & \\
\hline
\end{tabular}


5.0 QUESTIUIS AROUT WMS SYSTEM INFORMATION WITH ADDITIONAL INFORMATION KNOWR

This question is simllar to 4.0 except that the "NMS System Information" attribute (considered in Question 3.2 above) is considered with additional information provided about the other attributes. Please answer In a manner analcgous so Questiot 4.0 .

\begin{tabular}{|c|c|c|c|c|}
\hline \multirow{3}{*}{$\begin{array}{l}\text { Levels or } \\
\text { MMS } \\
\text { Information }\end{array}$} & \multicolumn{4}{|c|}{ Additional Information } \\
\hline & \multicolumn{2}{|c|}{ Motivation } & \multirow{2}{*}{$\begin{array}{c}\text { High } \\
\text { Technical Information } \\
\text { (c) }\end{array}$} & \multirow{2}{*}{$\begin{array}{c}\text { High } \\
\text { General Resources } \\
\text { (d) }\end{array}$} \\
\hline & $\begin{array}{c}\text { Money } \\
(a)\end{array}$ & $\begin{array}{l}\text { Weapon } \\
\text { (b) }\end{array}$ & & \\
\hline High & & & & \\
\hline Low & & & & \\
\hline
\end{tabular}

6.0 QUESTIONS ABOUT TECHNICAL INFORMATION WITH ADDITIONAL INFORMATION RNOWN Answer in a Manner Analogous to Questions 4.0 and 5.0

\begin{tabular}{|c|c|c|c|c|}
\hline \multirow{3}{*}{$\begin{array}{l}\text { Levels of } \\
\text { Technical } \\
\text { Information }\end{array}$} & \multicolumn{4}{|c|}{ Additional Information } \\
\hline & \multicolumn{2}{|c|}{ Motivation } & \multirow{2}{*}{$\begin{array}{c}\text { High } \\
\text { MMSS Information } \\
\text { (c) }\end{array}$} & \multirow{2}{*}{$\begin{array}{c}\text { HIgh } \\
\text { General Resources } \\
\text { (d) }\end{array}$} \\
\hline & $\begin{array}{c}\text { Money } \\
\text { (a) }\end{array}$ & $\begin{array}{c}\text { Weapen } \\
\text { (b) }\end{array}$ & & \\
\hline High & & & & \\
\hline Low & . & & & \\
\hline
\end{tabular}


7.0 QUESTIONS ABOUT GENERAL RESOURCES WITH ADDITIONAL INFORMATION KNOWN

Answer in a manner analogous to Questions $4.0,5.0$ and 6.0

\begin{tabular}{|c|c|c|c|c|}
\hline \multirow{3}{*}{$\begin{array}{l}\text { Levels of } \\
\text { General } \\
\text { Resources }\end{array}$} & \multicolumn{4}{|c|}{ Additional Information } \\
\hline & \multicolumn{2}{|c|}{ Motfvation } & \multirow{2}{*}{$\begin{array}{c}\text { Hizh MMS } \\
\text { System Information } \\
\text { (c) }\end{array}$} & \multirow[b]{2}{*}{$\begin{array}{c}\text { Technical Information } \\
\text { (द) }\end{array}$} \\
\hline & $\begin{array}{l}\text { Money } \\
\text { (a) }\end{array}$ & $\begin{array}{c}\text { Heapon } \\
\text { (b) }\end{array}$ & & \\
\hline High & & & & \\
\hline Low & & & & \\
\hline
\end{tabular}

\subsection{QUESTIONS ABOUT IMS SYSTEM ADVERSARY ARCHETYPES}

This section considers composite adversarles rather than concentratIng on varfous attributes of the adversaries as the previous sections did. In particular, nineteen archetypical adversaries are defined in F1gure 3. These archetypes should be thought of as collectively exhaustive and mutually exclusive. That $t a$, any adversary for an NMS System will be described by exactly one of these archetypes.

Please enter the relative likelihoods that an actual adversary will be described by each of the archetypes below. As you do this, consider the varfous factors which affect the 11kelihood that a theft would be Instigated by each of the archetgpes: their willingness to conmit a theft, the strength of the motive for stealing sqectal nuclear material, the relative value of accomplishing their goals through theft of special nuclear materlal as opposed to some other means, their percetved likelihood of a successful theft, and so forth. 
Because of the large number of categories, it is particularly important that you check your answers for consistency in the manner discussed in Section 3.0.

1. Uninformed Outsider

2. Principled Outsider

3a. Disgruntled Employee

3b. Disgruntled Employees

4. Principled Executive

5a. Competent Outsider

5b. Competent Outsider Group

6a. Opportunistic Employee

6b. Opportunistic Employees

7. High-Level Embezzl1ng Group

8. Embezzling Executive

9. Terrorist Group of Foreign National Group

10. Terrorist Individual

11. Insider Terrorist Group

12. Insider Terrorist Individual

13. Outsider Extortionist Group

14. Outside Expert

15. Extorting Eaployee

16. Extorting Executive 
1. Motivation

2. MMS System Information

3. Technical Informbtion

4. Consequence Information

5. Processing Capability
1. Symbolic: For example, game playing, prank, crazy, personal revenge, for principle, publicity for a cause, cover-up of material maccounted for

2. Money; To make money by sale of the material or ransom for its safe return

3. Extortion: Theft for nonmonetary gain (e.g., political gain, job restitution, prisoner release)

4. Weapon: Theft to make a weapon for eventual use (e.g., explosive device or radiation dispersal weapon)

1. High: Considerable knowledge of and control over at least one aspect of the Nuclear Material Safeguards System

2. Low: Has only the knowledge avallable to someone outside the MMS System

1. High: Has significant knowledge about nuclear science, computer technology, electronics and related areas

2. Low: Does not have significant knowledge about these areas

1. High: Full understanding of the possible legal, financial, social and health consequeaces of the theft attempt

2. Low: Incomplete understanding of the possible consequences

1. High: Has the equipment and expertise to process stolen material, either to make a weapon or to enrich or alter it for easler storage or sale

2. Low: Does not have such capabilities

Figure 2 DEFINITIONS OF ATTRIBUTE LEVELS 
6. General Resources

7. Self-Risk Attitude

8. Other's-Risk Attitude
1. High: A group of people with some experience in theft and criminal activity

2. Low: One or two people inexperienced in theft and criminal activity

1. Seeking: Adversary will take chances which threaten bis own life or welfare

2. Avolding: Adversary will not accept signiflcant probability of loss of life or capture

1. Seeking: Adversary 1s willing to risk lives and welfare of those not in adversacy group

2. Avolding: Adversary unwilling to do this 
1. Uninformed Outsidn:

2. Principled ütsider

3a. Disgruntled Employee

3b. Disgruntled Employees

4. Principled Executive

5a. Competent Outsider

5b. Competent Outsider Group

6a, Opportunistic Employee

6b. Opportunistic Employeeg

7. High-Level Embezzling Group
Theft for syrbolic reasons, prankster, crazy, far principle, but not planued; very 11ttle Nuclear Material Sajeguards System (NMSS) knowledge; technically unsophisticated

Theft for symbillc reasons (e.g., gameplaying, for principle); litcle or no MSS knowledge, technically sophusticated; could have ccusiderable diverston resources, but no inside contacts

Symbolic theft (e.g., labor uxrest, revenge on the system, MatertalUnaccounted-For coverup); MMS System luw-level insider, such as guard, minor technician, maintenance worker, etc.; little technical knowledge

Symbolic theft (e.g., for principle, revenge, coverup of present or future MUR); high level MMSS position and conracts (executive administrator, etc.); 11kely to understand consequences of thuft; high techalcal knowledge, possibly a group

Theft for monetary gain (e.g., future sale); 11ttle or no NMSS information; technically sophisticated; has diversion resources

Crime of opportunity, for money; knows one area of MASS (e.g., guard, loading dock worker, etc.); little technical sophistication

Possibly long-term diversion for profit: we1l-1nformed insiders; technically sophisticated; have MMSS contacts, control and equipment avallable

FIgure 3 MS SYSTEM ADVERSARY ARCHETYPES 
8. Embezzling Executive

9. Terrorist Group or Forefgn National Group

10. Terrorist Individual

11. Insider Terrorist Group

12. Insider Terrorist Individual

13. Outs1der Extortionist Group

14. Outs1de Expert

15. Extorting Empioyee

16. Extorting Executive
Crime oi opportunity, possibly long-term divers Ion; well-informed insider; techuically sophisticated

Theft to build weapon; little or no IMS System Information; high technical and processing capability; sophtsticated arms and adequate manpover (likely to mount a direct frontal attack)

Theft to bulld weapon; 11ttle or no MSS System Information; technically sophistcated and capable of processing material; few theft resources (likely to attack fringe of system, such as material belng transported)

Theft to bulld weapon; well-1nformed insiders; techoically sophisticated with processing capability: have IMS SysteI contacts, control and equiprent available (may be large group with theft equipment)

Theft to bulld weapon; well-1nformed Insier; technically sophisticated wich processing capability; 11ttle NMS System control and few contacts (small group or individual)

Theft for extortion; see (5b.) for other characteristics

Theft for extortion; see (5a.) for other characterietics

Theft for extortion; see (6a.), (6b.) for other characteristics

Theft for extortion; see (8.) for other characteristics 
APPENDIX A3

PROGRAM USER'S GUIDE

The Interactive computer program, discussed in Section 5.2, takes judgmertal probability fnformation about adversary attributes and produces bounds on the probabilities of the various archetypes. The program is conversational and prompts the user for necessary informatica. Examples of two different program runs are Included in Tables A3.1 and A3.2 and discussed below.

\section{A3.1 Normal Program Run}

The program run in Table A3.1 is fairly relf-explanatory. The notes below expand on items that may be unclear. The notes are keyed to the table, with tise number of the relevant note appearing in a clrcle in the leit margin of the table.

1. During the slgn-on process, a message is printed describing how to use the program.

2. With $E C H O=O F F$ certain infotmation describing the operations of the systerl is suppressed. This information would be distracting during the operation of the archetype probability bounding program. 
3. This starts the preprocessor program that sets un data for the linear programing solution procedure. If incorrect data is entered at some point during the operation of the program, it 1s safest to start over agala by hittiag the attencion key, and entering this command again.

4. The required format for data entry must be carefully followed.

5. At this point the uger has the four options listed with regard to whether he wshes to use the standard archetypes (defind in Figure 4.3) and/or standard exclusion rules (defined in Figure $4.2)$ or whether he wishes to use a new archetype he has fust defined.

6. At this point (after possibly a 1-2 mijute wait) some temporary files set up by the preprocessor have been sorted for use by the linear programming package.

7. Before this line is printed, there may be a delay of 3 to 5 minutes while the linear programing solution package carries out its work.

8. At this polnt the IBM linear programming package IPS has completed multiple runs to find the upper bounds on each of the archetype probabilities using the procedure discussed in Section 5.1. Due to the peculiar way MPS prepares output, an extremely large file is general: $/$ created, containing wuch information in addition to the bounds we seek. This file is now scanned for the information aeeded. It is also possible that the input data is Incernally Inconsistent. This case is discussed in Section A3.2. 
9. This command scans the large output file to cbtain the data desired. The numbers to the left of rUNCTIONAL should be dis" regarded. The output "." is shorthand for zero (0). Due to the large size of the output files, there may be a delay of 1 to 2 minutes unt1l the entire list of upper bounds is produced. An additional delay of 1 to 2 minutes is possible before the printing of the lower bounds.

10. Faulty data entry may result in meaningless output. In this case the command suggested will reveal the difficulty.

11. The run has been completed and a new run may be started.

\subsection{Run With Inconsistent Input}

The run shown in Table A3.2 11lustrates what happens if the input data is Internally Inconsistent. The notes below are ke yed to the table, with the number of the relevant note appearing in a circle in the left margin of the table.

I1. The data just Input is internally Inconsis :ent. This means there is no feasible solution to the archetype bounding problem. Entering SOURCE INFEAS produces the output on the next few lines. The eight-digit labe!s toward the left of the page 1dentify input probabilities using the code defined in Figure 5.1.

I2. In this example the probability input for $(3,1,2,1,1,1,0,0)$ appears to have contributed to the Infeasibility. 
I3. At this polat the output was stopped by hitting the 1aterrupt key, because it had progressed beyond the line where the cause of infeasibility was identifled. 


\section{TENle A3.1 NORMAL PROGRAM RUN}

(1) 1518 KJCF

IENTER USER GASGWORD.

3

ITERH , MORMAL, IUNTV

\$4LLAST SIGNON WAS: $20: 58: 32$ HON SEF $75 / 78$

- USER "KJCP" SIGNED ON AT 20:52:02 ON TUE SEF 23/78

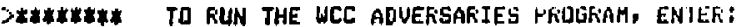

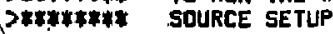

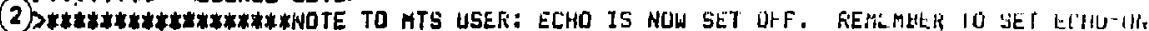
(3) Hounce sETHP

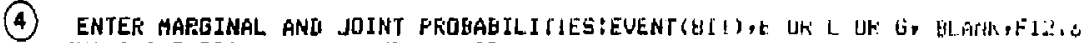
EXAMPLE 130200000E i 3 HEANS PKOB $($ YAR $1=3$, VAK $3=-2)=$, 3

ENTER 9 IF NO MORE

$?$

$10000000 E \quad .7$

$400000006+15$

$01000000 \mathrm{~L} .6$

$000100006 \quad .55$

?

$\frac{000000111.2}{?}$

(4) ENTER COMFAREU MakiginaL OR JOINT EVENTS

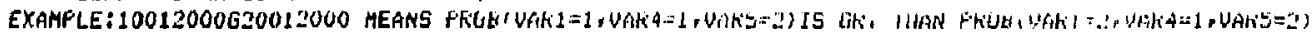
ENTER 9 FOR NO MORE

?

20000000030000000

?

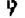

ENTEK CONUITIONAL FKUHAEILITIES

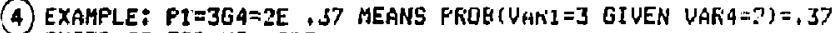

ENIER 99 FOR ND MOKE

?

$F \cdot 5=151=30 \quad .5$

99

TO ADD A NEW AKCHETYFE, ENTER 1, ELSE ENTER O

1

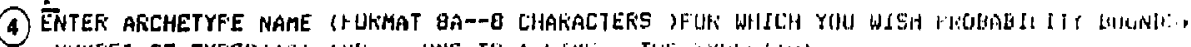
NUMEEF OF TYFES(12) ANL -- UNE TU A LINE - THE IYFLS(1U)

EXAMPLE:

NEWARTYF O3

112211.2

12211222

22211121

?

IESTIPFE 02

$\frac{11111111}{?}$

72727272 
Tabie A3.1 (continued)

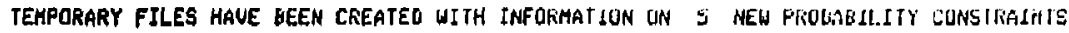

I CONOITIDNGL FRCGAEILITIES

1 COACAREL EVENTS

1 NEU PFI.HETYFES

\begin{tabular}{|c|c|c|c|}
\hline 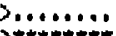 & & & \\
\hline & NOW ENTE & & \\
\hline 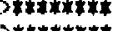 & & & \\
\hline 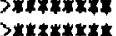 & SUURCE $F$ & LENAHE & \\
\hline$>$ > & WHERE ' $F$. & LENAME' DE & PENDS ON \\
\hline 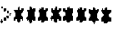 & STANDARE & EXCLUSION & SULSE \\
\hline 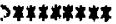 & & & \\
\hline$>* * * \neq * * * * *$ & FILENAME & STANDAF & | \\
\hline 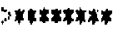 & & AREHETYPE & EXFULLES \\
\hline 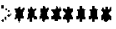 & & & \\
\hline 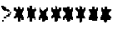 & DATA1 & NO & MO \\
\hline 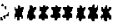 & UATA2 & Na & YES \\
\hline 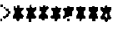 & DATA3 & YES & Na \\
\hline 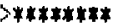 & DATAA & YES & YES \\
\hline
\end{tabular}

(5) FSTURCE DATA4

SORT $=$ CHIAISTB INFUT $=-$ IN OUTFUT $=-$ SDKTED

6) Statistics: 2E76r

(7)

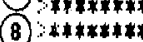

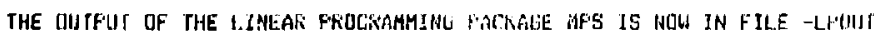

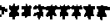

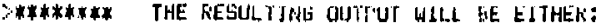

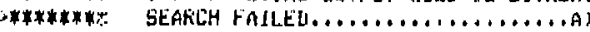

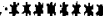

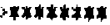

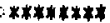

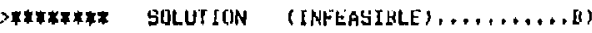

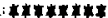

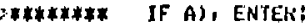

\#******* SOURCE SCAN?

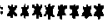

H******* IF B:, ENTEKi:

***\#\#\#\#* SOUKC,E INFEAS

iseoren failed

(9) ISOHKCE SCAN? 
Table A3.1 (continued)

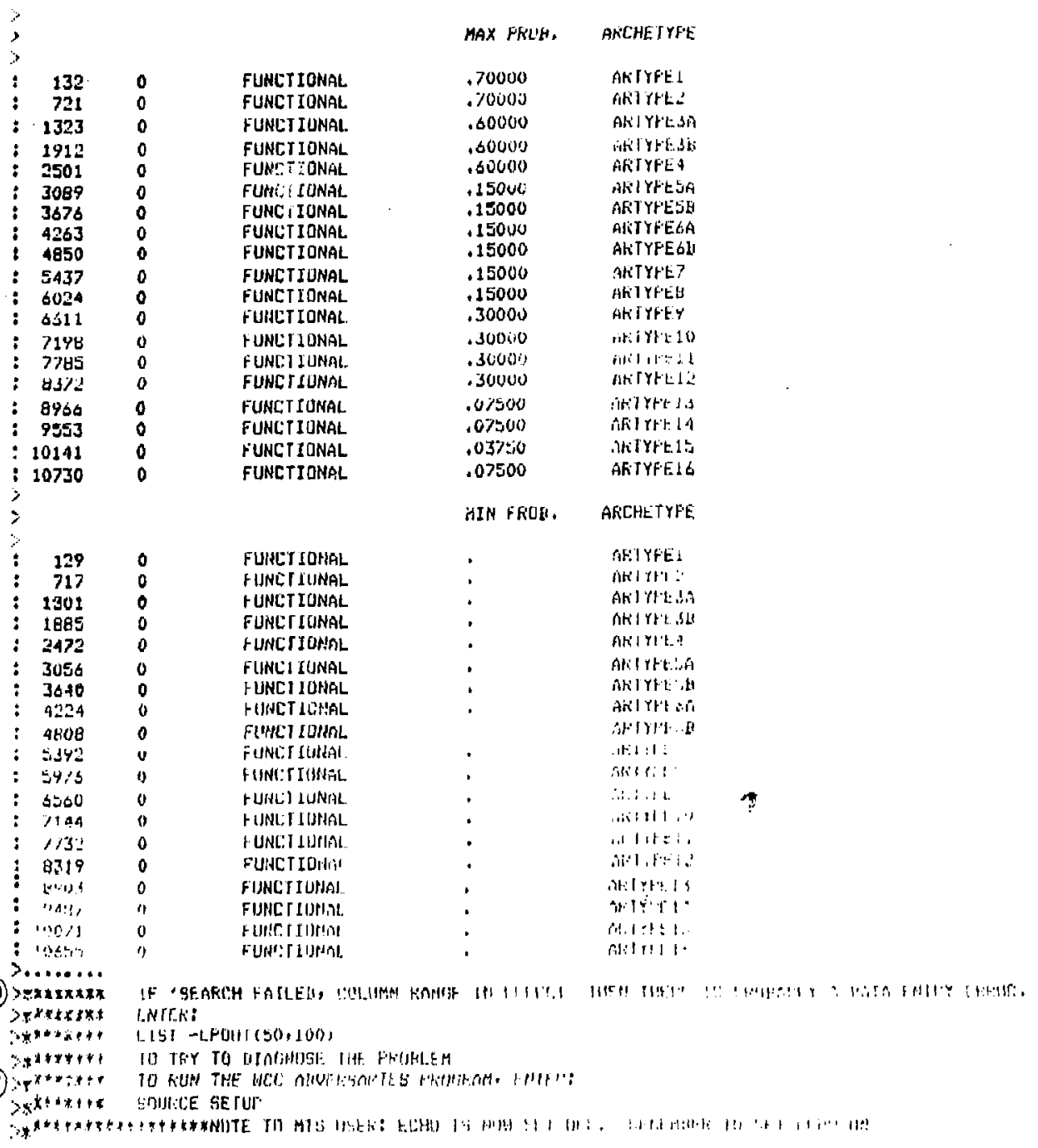




\section{Table A3.2 RUN WITH INCONSISTENT INPUT}

DSUUNITE BLIUR

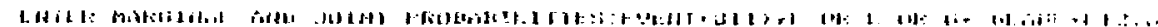

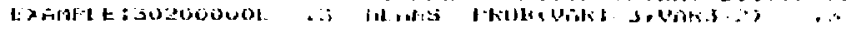

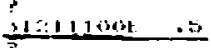

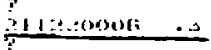

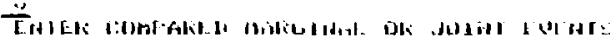

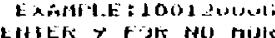

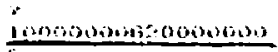

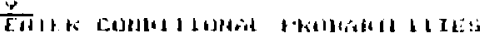

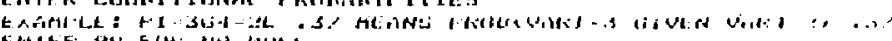

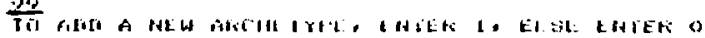

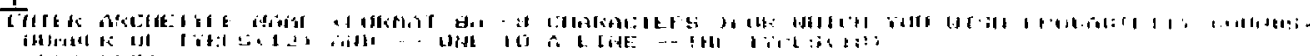

III Widitire o.

Ii, Witis

$12+1012+2$

$2: 21112$

iI:ilitit 02

111111

220.1225 
Table A3.2 (continued)

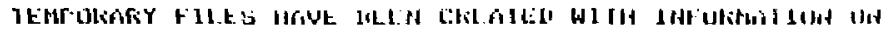

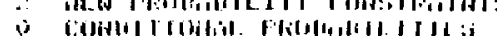

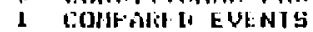

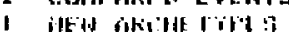

HUS EHTLK:

Hitionitik

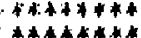

$+*+1+k+4$

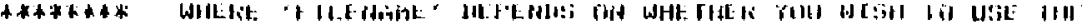

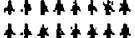

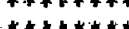

$k+k+k+k$

$+4+k+k+4$

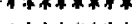

$\therefore+t+1+k$

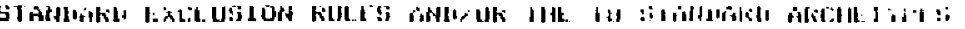

F ILENÁAlE

STMHLAfil STringakI

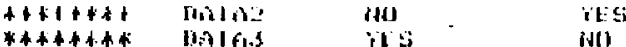

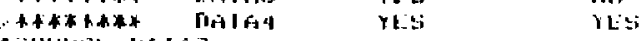

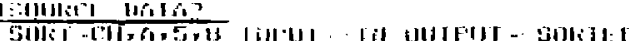

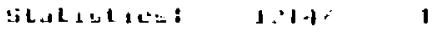

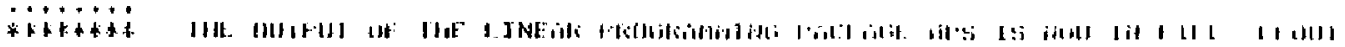

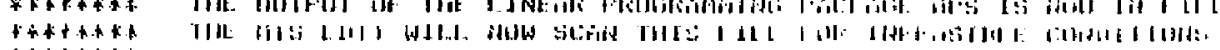

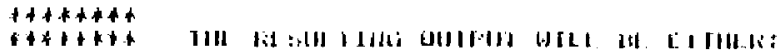

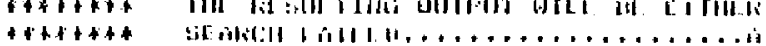

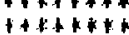

At+itidta

$+1+k+k+1$

Antitith

$+6+k+4 k$

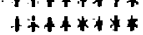

$+t+t+t *$

$+\ldots 1+k+k *$

IIS

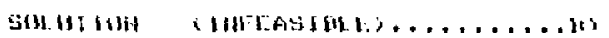

11 Ar, Eidtili:

fulliti. silinis:

II It', 1 HAlli:

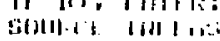

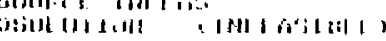




\section{Table A3.2 (continued)}

(ii), ict. lint tin:

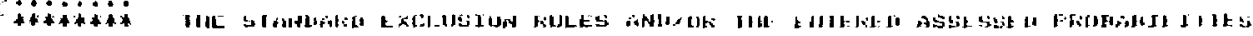

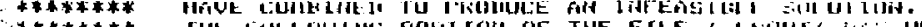

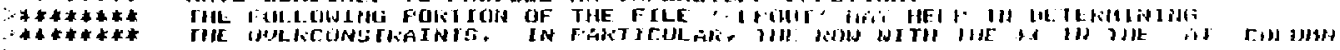

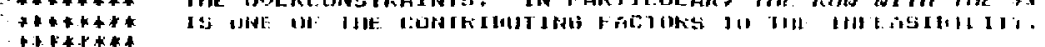

(12)

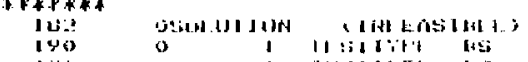

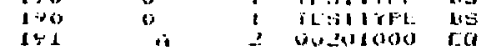

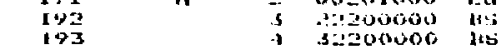

$19-1$

175

194

197

194

200

201

203

20.1

205

:is

$\vdots \quad \vdots i 3$

(13)
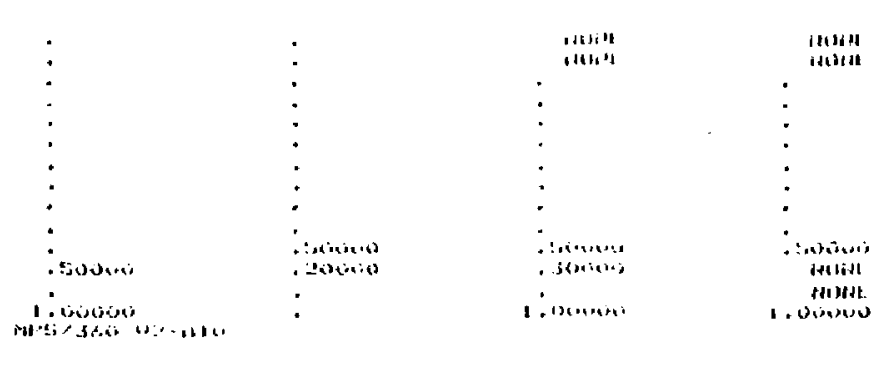

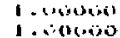

3.200000

40600002

41101400 ing

300.0000 115

$31.11100 \quad 4 *$

i) $1 \%$ loll tatbril 11

1 1 1.5 bIJ" lin

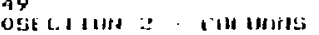

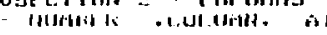

1) 1 inatil il

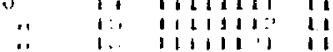

$\therefore \quad r$ lilitio li.

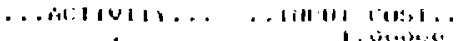

a11116: InI1.

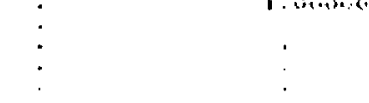

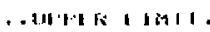

Git Lath II I IES?

mar!t:

i!).

1.titions 
APPENDIX A4

TRANSLATION OF QUESTIONNALRE RESPOESES

I.TO PROGRAM INPUT DATA

This appendix dedonstrates the cranslation of questlonnalre responses into coded forin suitable for input into the preprocessor couputer program.

The procedure is strafghtforma.i:

a. Convert relative likellhoods into probabilities, by ividing each likelihood by the sum over all levels;

b. Identify the appropriate code for the marginal or condicional probability involved.

For example, consider expert A's responses to Question 3.1 (see Figure 7.2).

Motivation Relative Likelihood

1. Symbolic 1

2. Money 10

3. Extortion 5

4. Weapon 3

Since the sum of the relative likelihoods is 19 , we have 


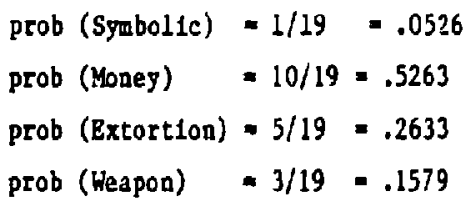

Using the notation of Pigure 4.L, this set of judgments becomes:

$$
\begin{aligned}
& P(1,0,0,0,0,0,0,0)=.0526 \\
& P(2,0,0,0,0,0,0,0)=.5263 \\
& P(3,0,0,0,0,0,0,0)=.2633 \\
& P(4,0,0,0,0,0,0,0)=.1579
\end{aligned}
$$

Note that it 18 only necessary to enter three of the four probabilities, sluce the fourth 1s always constrained so that they all sum to 1. For the preprocessing program, the "z" signs are entered as " $\mathrm{E}$ ".

S1uilarly, expert A's response to the f1rst part of Question 4.0 would be coded:

$P\{(1,0,0,0,0,0,0,0)$ given High MMS information $\}=1 / 18=.0556$

$P\{(2,0,0,0,0,0,0,0)$ given High NMSS inforwation $\}=10 / 18=.5556$ $P\{(3,0,0,0,0,0,0,0)$ given High NMSS information $\}=5 / 18=.2778$

In terms of the format required by the preprocessing program, this becomes:

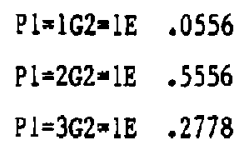


Firaliy, for the qualitative conditionyl judgments of expert $C$ we write, for example, for the first part of Question 4:

$$
P 1=1 G 2=1 G \quad .1667
$$

EIgure A4.1 shows the coded translation of the fudgments of F1gures 7.1 and 7.2 . 


\begin{tabular}{|c|c|c|c|c|}
\hline & & t & B & C \\
\hline 3.1 & $\begin{array}{l}(1,0,0,0,0,0,0,0) \\
(2,0,0,0,0,0,0,0) \\
(3,0,0,0,0,0,0,0)\end{array}$ & $\begin{array}{l}=.0526 \\
=.5263 \\
=.2632\end{array}$ & $\begin{array}{l}=.5882 \\
=.0588 \\
=.2941\end{array}$ & $\begin{array}{l}=.1667 \\
=.1667 \\
=.5\end{array}$ \\
\hline 3.2 & $(0,1,0,0,0,0,0,0,0)$ &.- .5 & $=.6667$ & $=.9091$ \\
\hline 3.3 & $(0,0,1,0,0,0,0,0)$ &. .7 & $=.6667$ & -.75 \\
\hline 3.4 & $(0,0,0,0,0,0,0,0)$ & -.7 & -.5 & $=.9091$ \\
\hline 4.0 & $\begin{array}{l}P 1=1 G 2=1 \\
P 1=2 G 2=1 \\
P 1=3 G 2=1\end{array}$ & $\begin{array}{l}=.0588 \\
=.5882 \\
=.2941\end{array}$ & $\begin{array}{l}=.25 \\
=.25 \\
=.25\end{array}$ & $\begin{array}{l}G .1667 \\
L \cdot .1667 \\
L .5\end{array}$ \\
\hline & $\begin{array}{l}P 1=1 G 3=1 \\
P 1=2 C 3=1 \\
P 1=2 G 3=1\end{array}$ & $\begin{array}{l}=.0588 \\
=.5882 \\
=.2941\end{array}$ & $\begin{array}{l}=.25 \\
=.25 \\
=.25\end{array}$ & $\begin{array}{l}G .1667 \\
L . .1667 \\
L .5\end{array}$ \\
\hline & $\begin{array}{l}P 1=166=1 \\
P 1=2 G 6=1 \\
P I=3 G 6=1\end{array}$ & $\begin{array}{l}=.0588 \\
=.5882 \\
=.2941\end{array}$ & $\begin{array}{l}=.25 \\
=.25 \\
=.25\end{array}$ & $\begin{array}{l}\mathrm{L} .1667 \\
\mathrm{G} .16067 \\
G .5\end{array}$ \\
\hline 5.0 & $\begin{array}{l}P 2=1 C 1=2 \\
P 2=1 G 1=4 \\
P 2=1 G 3=1 \\
P 2=1 G 6=1\end{array}$ & $\begin{array}{l}. .6250 \\
=.4 \\
=.1667 \\
=.5\end{array}$ & $\begin{array}{l}=.9091 \\
=.0095 \\
=.5 \\
=.5\end{array}$ & $\begin{array}{l}\text { L } .9091 \\
\text { G } .9051 \\
\text { G } .9091 \\
\text { C } .9091\end{array}$ \\
\hline 6.0 & $\begin{array}{l}P 3=1 G 1=2 \\
P 3=1 G 1=4 \\
P 3=1 G 2=1 \\
P 3=: 36=1\end{array}$ & $\begin{array}{l}=.6250 \\
=.4 \\
=1.0 \\
=.5\end{array}$ & $\begin{array}{l}=.625 \\
=.6667 \\
=.5 \\
=.5\end{array}$ & $\begin{array}{l}\text { I. } .75 \\
\text { G } .75 \\
\text { G. } .75 \\
\text { G. } .75\end{array}$ \\
\hline 7.0 & $\begin{array}{l}P 5=1 G 1=2 \\
P 6=1 G 1=4 \\
P 6=1 G 2=1 \\
P 6=1 G 3=1\end{array}$ & $\begin{array}{l}=.567 \\
=1.0 \\
=1.0 \\
=.5714\end{array}$ & $\begin{array}{l}=.9091 \\
=.9524 \\
=.5 \\
\pm .5\end{array}$ & $\begin{array}{l}=.9091 \\
\text { C. } .9091 \\
G .9091 \\
\text { G . .9091 }\end{array}$ \\
\hline
\end{tabular}

I1gure 44.1 CODED TRANSLATION OF JUDGMENTS OF FIGURES $7.1,7.2$ 
Understanding the operations of the programs that calculate bounds oil archetype probabilities requires understanding the IBM Kathematical Frograming System program MPS. This is documented in detall in Appe:diz A6. With an understanding of MPS, the annotated 11sting of S.SETUP, the preprocessor source program, which is given in Appendix A7, should be relatively easy to follow. The remataing files listed in Appendix A7 are (1) command (SOURCB) files which contain instructions to the Michigan Terminal System to carry out various file mantpulations necessary to prepare data for MPS or interpret the output of MPS; (2) permznent data f1les which contain either instructions for MPS or data on the archetypes or exclusion rules; or (3) temporary data files prepared by the obfect program 0, SETUP for XPS or containing output from MPS. The function of each file is briefly explained beiow.

\section{A5.1 Command Files}

DATA1: Sets up files for MPS if nonstandard archetypes and standard exclusion rules are to be used.

DATA2: Sets up files for MPS if nunstaudarà archetypes and standard exclusion rules are to be used.

DATA3: Sets up files for MPS if standard archetypes and nonstandard exelusion rules are to be used.

DATA4: Sets up files for MPS if standard archetypes and exclusion Iules are to be used.

START: Prints message explaining how to use prograns. 
SETUP: Contains the comands necessary to run the preprocessor program.

R.UNLP: Runs IPS and checks output for infeasibility,

SCAN2: Scans output flle from MPS to find bounds on archetype probais11ties.

INFEAS: Scass output ille frow MPS to determlne cause of Infeasiblilty lf laput data was inconsistent.

MFSSAGE: Contains explanatory wessages printed out by several diffarent comand flles when they are executed.

\section{A5.2 Permanent P1les}

COMMAND: Remaiader of Instruction file and top of iaput data file for MPS If standard ar hetypes are to be used.

MAX: Top of instruction file for WPS If upper bounds on archetype probabillties are desired.

MIN: Top of Ingtruction flle for MPS if lower bounds on archetype probabilities are degired.

END: Fad-of-data marker for MPS.

RULEROWS: Names of constraint rows to implement standard exclusion rules.

RULESRHS: Probab1lities to implement exclusion rules named in RULEROWS.

EXRULES: Definitions of constraints to implement standard exclusion rules.

TYPFILE: Definitions of standard archetypes.

TYPROWS: Names of objective function rows to implement archerypes.

S.SETUP: Source program for 0.SETUP.

O.SETUP: Object code for preprocessor that sets up data for input to MPS. It creates files $-\mathrm{F} 2,-\mathrm{F} 3,-\mathrm{F} 7,-\mathrm{F} 8$, and $-\mathrm{F} 9$. 
ROHSFILE: Names of a prevlously stored set of assessed probabllities to be used as Inpue data for MPS.

RHS: Prevlousiy stoted set of values for the probabilf:les named in ROWSFILR.

\section{A5.3 Tegporary F11e日}

-F2: Corresponds to COMANDS when nonstandard archetypes are to be used.

-F3: Corresponds to ROWSFILE If a new set of assessed probability data is to be used.

-P8: Corresponds to RHS if a new set of assessed probability data is to be used.

-F9: Corresponds to TYPPILE if nonstandard archetypes are to be used.

-F7: Standard row coefficlents for MPS.

-LPOUT: File containing output data from MPS.

-LP: Final laput file for MPS. 
Reprinted from:

W. K. Hall, A. MeWhorter, and W. A. Spivey, "Optimization Programs at the University of Michigan," Second Edition, Graduate School of Business Administration, The University of Michigan, Ann Arbor, Michigan. 
I1I. MATHEYAICAL PROCRAMING SYSTEM/360

\section{A. D:SCRIPTION OF PROGRAM}

The IMM Mathematical Programing Systen/360 consists of three major programs. Although this write-up w1ll provlde an iatroduction to only tho first of these programs, a brief description of all three is provided below:*

1. MPS/ $\$ 60$. This program contains a set of linear and sepaxable proeramming algortthes, a control language compiler, and a FORTRis inte:face called READCOMM.

The linear programming algortthm and the associzted control language compiler are docimented ir this manual. ${ }^{\star *}$ Ti.ts algoricho uses the revisei siaplex method with the product form of the inverse. (See keferences d. and 11 for a discussion of the algortthm.) Additfona! algoratrm fcatures include scaling, multiple prfcing, restricted basis entry, and vepar bouiding. Fie maxioum probien size is 4095 ruws with avirtually unlimited aumber of coicmas.

The separable programming algorithm allows the user to analyze certail classes of non-linear progranming froblems where the objective fuaction and constraints can be written as linear combinations of functions of a single varlisble. This algoritha utilizes plece-wise innear approximation cf the nun-linear functlons to reduce the problen to a linear programing problem with restricted basis entry. Documentation of these features is currently in progress.

READCOMM is a subroutine designed to transfer MPS/360 dara, MARVEL/360 data (see Part 3 in Lhis section), and control language parameters to FOR.RR.N procedures which have been written by the user and incorporated under lie control of MPS/360. Reference 6 provides complete documertation on this routine.

2. MPS/360 Report Generator (MPSRC). This program consists of a report language and three procedures that compile and execute the main program; Reference 7 documents these procedures.

3. WARVEL. This program is a language prcze- or for tatrix generation, file maincenance, output analysis, and management repor: writing. MARVEL can access (from an IPS/360 program) the original input data, results, or any auxiliary data required to produce management reports or new input data fcr a subsequent mathematical programing run. References 8 and 9 docunient the MARVEL processor.

*The reader is referred to Reference 3 , which provides a more detailed over'iew of the concepts and features of this sof tware system.

${ }^{* *}$ Referances 4 and 5 provide the IBK documentatiun on $\downarrow$ LF algorithm and concrol languge compiler. The user should consuit these to uriliza aduanced teatures of these programs. 
All of the programs in this software package are written in OS/ 360 assembly language, and double prectsion is used in most of the linear programming procedures.

The size of MPS $/ 360$ is approximately $32 \mathrm{~K}$ bytes ( $\mathrm{k}=1024$ ). A minimum system configuration for running $\mathbb{P P S} / 360$ is a $64 k$-byte 360 with standard and decimal instruction sets, floating point, and a 132-position print line (1.f the system output is a printer). MPS/360 supports the 24000 series magnetic tape units and the 2311,2314, 2301, 2302, 2303 direct access devices.

Effective March, 1973, MPS/360 will be available in MTS. Users who are familiar with earlier versions of this monograph should realize that it is no longer necessary to run MPS/360 under IBM's operaring system (OS/360).

B. GENERAL FORM OF THE INPUT STREAM

The job control cards, source program (written in $\mathbb{P} S$ ), and daca cards for a problem run in MPS will take the general form outlined below:

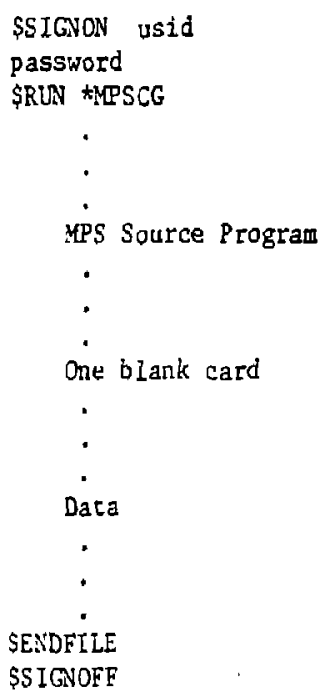

where "usid" is the user's 4-character computing center iD number and "password" is the user's password. As a note to the experienced MTS user, AMSCG uses logical units SCARDS and SPRINT for input and output, respectively. 


\section{INSTRUCTIONS IN IMPS}

1. Format--The compiler recognizes MPS prog:ams written in either free or fixed format. The rules for fixed format are:
Columns
Contents
1-8 Label (optiona1)--contains 1-8 alphabetic (A-Z) or numeric (0-9) characters; first character must be alphabetic, but cannot be an X. Embedded blanks are not allowed.

$9 \quad$ Blank
10-71 Operation Name and (optiona1) Arguments or arithmet1c expres- sion. Either statenent must begin in co? 10 .
72 Continuation--a nonblank character in co. mn 72 indicates that this statement continues in column $l$ of $t=$ following record. This character is not considered part of tive statement.

(Coments may be included anywhere in the source prog:am or the data deck by entering an asterisk in column 1).

2. Required Statements--For our purposes, the following 8 statements will be required in any MPS program.

(1) PROGRAM--first statement in the source program.

(2) INITIALZ;-second statement in the source program.

(3) EXIT--next-to-last statement in the source program.

(4) PEND--last statement in the source program.

(5) MOVE--This statement moves data from one location to another. We will assume that a minimum of the following 4 MOVE statements will be required in any MPS program:

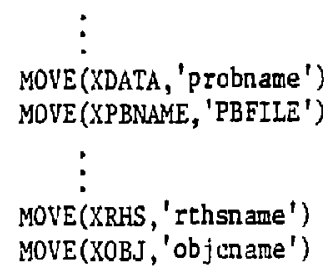

where probname $=$ name of the problem as defined on the NAME card of the input data.

rthsname $=$ name assigned to the right-hand-side vector as defined on the COLimN cards following the RHS card in the input data.

objcname = name assigned to the objective function on one of the unconstrained ROWS cards in the input data.

as specified).

(All other characters in the 4 MOVE statements listed above are required 
(1) CONVERT--This statement causes the input file to be read into an area called PROBFILE. Heading information and an error sumarary by input section is printed. If the optional parameter 'SUMMARY' is included (i.e., CONVERT ('SIMMARY')), MPS produces a 2-page summary listing concerning the columns and rows of the original matrix. (See section $H$. for discussion of output.) This statement must be preceded by the first two YOVE statements referenced in 0.2 , above.

(2) BCDOUT--This statement produces a listing of the input data.

(3) SETUP--This statement must be preceded (although not immediately) by the CONVERT statement. SETUP allocates storage, initializes input/ output, creates a work matrix, and determines an initial solution. It is essential to note that MPS assumes all problems to be minimization problems. The progran user can override this convention by writing SETUP ('MAX') instead of SETUP.

The SETYP statement must also be modified when there are finite upper bounds or non-zero lower bounds on the decision variables. In these situations the statement should read SETUP('BOUND', 'XXXX'), where $\mathrm{xuxX}$ is the user-supplied nane of the row vector in the BOUNDS section of the dąta set containting the upper and lower bounds.

In certain situations various problen constraints will be required to lie within a certain range of values. Here the SETUP statement should read SETUP('RANGE', 'YYYY'), where YYYY is the user-supplied name of the column vector in the RANGES section of the data set containing the valid constraint ranges.

When a problem requires maximization and when bounds and ranges are present, the SETUP statenent would read SETUP('BOUND', 'XXXX', 'RANGE', 'YYYY', 'MAX').

(4) PICTCRE--This statement will cause a condensed, "coded" representation of the current matrix to be printed. The format of this output is discussed in Section 2.

(5) PRIML--This is the main optimization procedure in VPS. It is based on the revised simplex algorithm and terminates with (1) an optimal solution, (2) an infeasible solution, or (3) an unbounded solution. This statement must be preceded by the second 2 NOVE statements discussed in C.2. above. The output produced by PRIAAL is discussed in Section ii.

(6) DUAL--This statement offers an alzernate method of solving an LP problem and is particularly useful if there are more rows than columns in the original matrix. However, since DUAL can only guarantee a feasible solution, PRIMAL must be called after DUAL to ensure optimality. 
(i) SOLiTION--This statement causes the current solution of the LP problem to be printed. The content of chis output is discussed in Section $H$.

D. THE IXPUT DATA

There are two types of input cards--indicator cards and data cards. Data is entered in the crder NAME, ROWS, COLINNS, RHS, RANGES, BOUNDS, as specified by the corresponaing indicator cards. A description of these sections of the input daca deck iollows:

1. WAE--Always the firse card of the data deck; included to uniquely identify the data.

\section{(1) Indicator Card Format}
Co1 $1+4$
NAME
$\operatorname{Col} 15-22$
A name assigned to the data (generally the same name moved into XDATA in the MPS control program)

(2) Data Card Format

The Whe section requires no daca.

2. Rots--This section describes the rows of a linear programing tableau by assigning names to the rows and by indicating the type of constraint represented by the row.

(1) Indicator Card Format

Co1 1-4 ROWS

(2) Data Card Format

Col 2 Type of constraint coded as follows:

iv No constraint (the objective function or a change row to be used in parameterization)

G Greater than or equal to

L Less than or equal to

E Equality

$\operatorname{col} 5-12$ The user-essigned name of the row (left-justified)

3. Uthos--This section describes the columas of the linear programming tableau ossigning names to the columns and also contains the non-zero cost and coe:icient inpur data for the problem. 
(1) Indicator Card Format

Col 1-7 COLUMS

(2) Data Card Format

Col 5-12 The user-supplied name of the columns (leftjustified).

Col 15-22 The name of the row in which a data element is being entered (left-justified).

Col 25-36

The value of the data element (Fortran E notation is pernissible).

$\operatorname{Col} 40-47$

Optional. The name of a sacond row in which a data element is being entered.

$\operatorname{Col} 50-61$

$\therefore$-ional. The value of the second data element.

Note: Matrix elements must be entered by column. That 1s, all nonzero elements in each column nust be specified before a second column is named. Zero elements need not be specifled,

4. RHS--This section describes the requirement vector and any column parameterization vectors of the linear programming tableau by assigning names to nonzero data entries of these vectors.

(1) Indicator Card Format

$\operatorname{Col} 1-3$

RHS

(2) Data Card Format

The data card format is identical to that of the colneNs section.

5. RANGES-This section describes the ranges within which problem constraints are required to lie. It is not included in the input data stream when the problem requires no ranges.

(1) Indicator Card Format

CO1 1-6 RAVGES

(2) Data Card Format

$\operatorname{col} 5-12$

The user-supplied name of a column vector designated to contain the ranges (left-justified). 
$\operatorname{Col} 15-22$

Col 25-36

Co1 $40-47$
The name of the row to which a range is to be applied (left-justified).

The value of the range ( $r_{i}$ in the table below).

Optional. The name of a second row to which a range is to be applied.

$\operatorname{Col} 50-61$

Optional. The value of the second range.

Ranges are applied to constraints as shown in the following table, where $b_{i}$ is the value spectfied on the RHS data card for row $i$ and $r_{i}$ is the corresponding range.
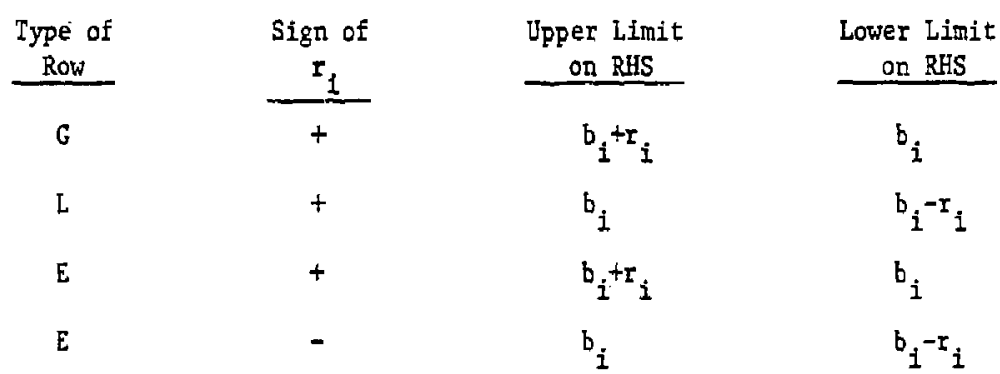

6. BOUNDS--This section describes finite upper bounds or non-zero lower bounds on the problem decision variables. It is not included in the input data stream when the decision variables are only restricted to be don-negative.

(1) Indicator Card Fornat

$\operatorname{Col} 1-6$

BOUNDS

(2) Data Carc Format

$\operatorname{Col} 2-3$

Type of bound as indicated by the following symbolism
Lo Lower bound
UP Upper bound
FX Fixed Variable
FR Free Variable $\left(-\infty<x_{i}<\infty\right)$
MI Lower bound of $-\infty$
PL Upper bound of to

Col 5-12

The user-supplied name of a row vector designated to contain the bounds (left-justified).

$\operatorname{col} 15-22$

The name of the column corresponding to the variable which is to be bounded. 
$\operatorname{Col} 25-36$

If $\operatorname{CoI} 2-3$ contains LO, JP, or EX, this field contains the value of the associated bound. Otherwise it is left blank.

Note: It is possible to specify both upper and lower bounds or only one bound for a decision variable. In the later case, the unspecified bound remains at its original value of 0 or $+\infty$.

7. ENDATA-Always the last card of the data deck. Used to indicate the end of the current data set.

(1) Indicator Card Format

Col 1-6 ENDATA

(2) Data Card Format

The ENDATA section requires no data.

E. SAMPLE PROGRAY 1

YTS/360:

Assume that you have been asked to solve the following problem using

$$
\begin{aligned}
& \text { Maximize } f=x_{1}+3 x_{2}+5 x_{3}+4 x_{4}+9 x_{5} \\
& \text { Subject to: } 3 x_{1}+2 x_{2}+4 x_{3}+x_{4}+5 x_{5}=15 \\
& x_{1}+2 x_{2}+x_{3}+5 x_{4}+5 x_{5}=13 \\
& 2 x_{3}+3 x_{4}+3 x_{5} \leqq 6 \\
& x_{j} \geq 0, \quad(j=1, \ldots, 5) \text {. }
\end{aligned}
$$

Assume further that your user number is X527, your password is KINGKONG, and you have decided to name your problem and the data TRIALRUN. You have also decided to give the objective function (row) the name OBJ and the three constraint rows the names $R 1, R 2$, and $R 3$ respectively. Further, you have given the columins corresponding to the decision variables the names $\mathrm{Cl}, \ldots, \mathrm{C5}$ respectively, and the column vector of constants (the requirement vector) the name BVEC.

The form that the complete program should take, including fob control cards, source program, and data, is given on the computer listing that follows. 
\$SIGNON X527

KINGKONG

\$RUN *MPS

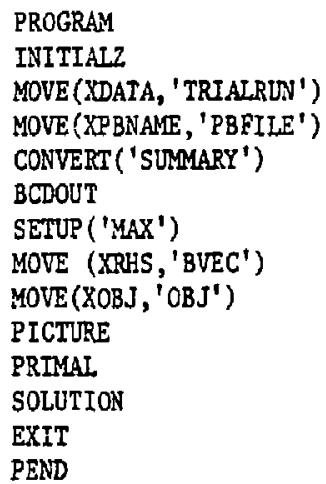

PROGRAM

INITIAL2.

MOVE (XDATA, 'TRIALRUN')

MOVE (XPBNAME, 'PBFILE')

CONVERT ('SUMMARY')

BCDOUT

SETUP ('MAX')

MOVE (XRHS, 'BVEC')

MOVE (XOBJ, 'OBJ')

PICTURE

PRIMAI.

SOLUTION

EXIT

PEND

(blank card)

NAME

TRIALRIN

ROWS

$N$ OBJ

E RI

E R2

L $R 3$

COLIMNS

$\begin{array}{lllll}\text { C1 } & \text { OBJ } & 1.0 & \mathrm{R} 1 & 3.0 \\ \text { CI } & \text { R2 } & 1.0 & & \\ \text { C2 } & \text { OBJ } & 3.0 & \mathrm{R} 1 & 2.0 \\ \text { C2 } & \text { R2 } & 2.0 & & \\ \text { C3 } & \text { OBJ } & 5.0 & \mathrm{Rl} & 4.0 \\ \text { C3 } & \text { R2 } & 1.0 & \mathrm{R} 3 & 2.0 \\ \text { C4 } & \text { OBJ } & 4.0 & \mathrm{R} 1 & 1.0 \\ \text { C4 } & \text { R2 } & 5.0 & \mathrm{R3} & 3.0 \\ \text { C5 } & \text { OBJ } & 9.0 & \mathrm{R} 1 & 5.0 \\ \text { C5 } & \text { R2 } & 5.0 & \mathrm{R} 3 & 3.0\end{array}$

RHS

$\begin{array}{lllll}\text { BVEC } & \mathrm{R} & 15.0 & \mathrm{~B} 2 & 13.0\end{array}$

ENDATA

SENDFILE

SSIGNOFF

F. POSTOPTIMALITI STATEMENTS (OPTIONAL)

1. RAiGE--This statement outputs a sensitivity analysis of the current solution, including:

(1) The effects of cost changes on optimum activity levels. 
(2) The cost of changing an activity from the optimum level and the activity range for which this cost is valid.

(3) The value of changing a row activity level and the interval for which the value is valid.

The mathematics underlying these procedures is documented in reforence (11; pp. 180-196), and more complete discussion of the output from RANGE is given in Section $\mathrm{K}$.

2. PARARHS--This statement enables the programmer to parameterize the RHS. From the original LP problem, a series of related problems is defined by replacing the current RHS with a new RHS obtained by incrementing each element of the original RHS by some multiple of a corresponding term of a user-spectfied change column. The multiple, and its maximum value are supplied as described below. Four statements must precede the PARARHS statenent:

(1) MOVE(XCHCOL, ' $\mathrm{xxxx \times x \times x}$ ') where $\mathrm{xxxx \times xxx}$ is the name of a change column which the user has defined in the RHS section of the matrix.

(2) XPARAH $=0$

(3) XPARMAX $=m$ where $m$ is the required maximum value of the parameter (uust be >0, must contain decimal point).

(4) XPARDELT $=p$ where $p$ is the parameter interval at which a solution will be printed (must be $>0$, must contain decimal point).

The solution is kept optimal and feasible by changing the basis when necessary. The output from this option is discussed in $S$ ection $H$. The mathematics underlying PARARHS is documented in Appendix A. Similar mathematical procedures apply to the parameterization options discussed in 3-6 below.

3. PARARIM--This statement enables the programer to simultaneously parameterize the RHS and the objective function. This procedure is essentially identical to PARARHS with the additional stipulation that a user-specified change row (to be used for parameterization of the objective iunction) is required. The following 5 statements must precede PARARIM:

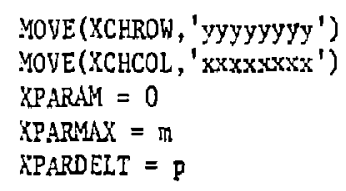

where yyyyyyy is the name of a change row and all other names, etc., are identicai to the explanation of PARARHS. The solution is kept optimal and Eeasible by changing the basis when necessary. The output of PARARIM is discussed in Section $H$. 
4. PARACOL--This statement enables the programer to parameterize a structural column using a user-specified change column which is defined in the RHS section of the data input. This procedure is essentialiy identical to XPARARHS. The following 5 statements must precede the PARACOL statement:

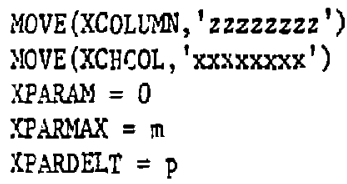

where zzzzzzzz is the name of the column that is to be parameterized. The solution is kept optinal and feasible by changing the basis when necessary. The output of PARACOL is discussed in Section $\mathrm{H}$.

5. PARAROW--This statement enables the programer to parameterize a constraint row. The procedure is simllar to XPARARHS. The following five stacements must precede the PARARON statement:

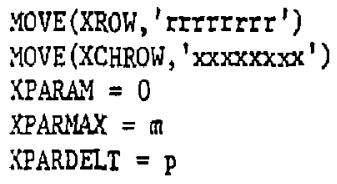

sinere rrrrrrrr is the name of the row to be parameterized, and must be a constraint row, and $x \times x \times x \times x x$ is the name of the user-specified change row. The solution is kept optimal and feasible by changing the basis when necessary. The output of PARAROW is discussed in Section $H$.

6. PARAOBJ--This statement enables the programer to parameterlze the objective row. The procedure is similar to PARAROW. The following 4 statements must procede PARAOBJ.

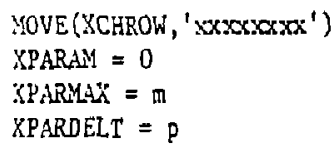

where $\operatorname{xxx\times x\times x\times }$ is the name of the change row. The solution is kept optimal and fasible by changing the basis when recessary. The output from PARHOBJ is discussed in Section $H$.

\section{G. S.ITPLE PROGRAN 2}

Assume that you have been asked to conduct a RANGE analysis and then Franeterize the RHS in the sample progiam from section E. In particular, you ir s uked to decermine the effect of decreasing the 12 in constraint aquation 1 Erom 15 dewn to 0 in decroments of 1 (1.e., $15,14,13, \ldots, 0$ ), while holding all the ather equations constant. A vector of the form $\left(-\frac{1}{j}\right)$ must be set up in the RHS

section to accomplish this parameterization. The computer listing which follows indicates how this post-optimality option might be handled when this change vector has been given the name BSTAR. 


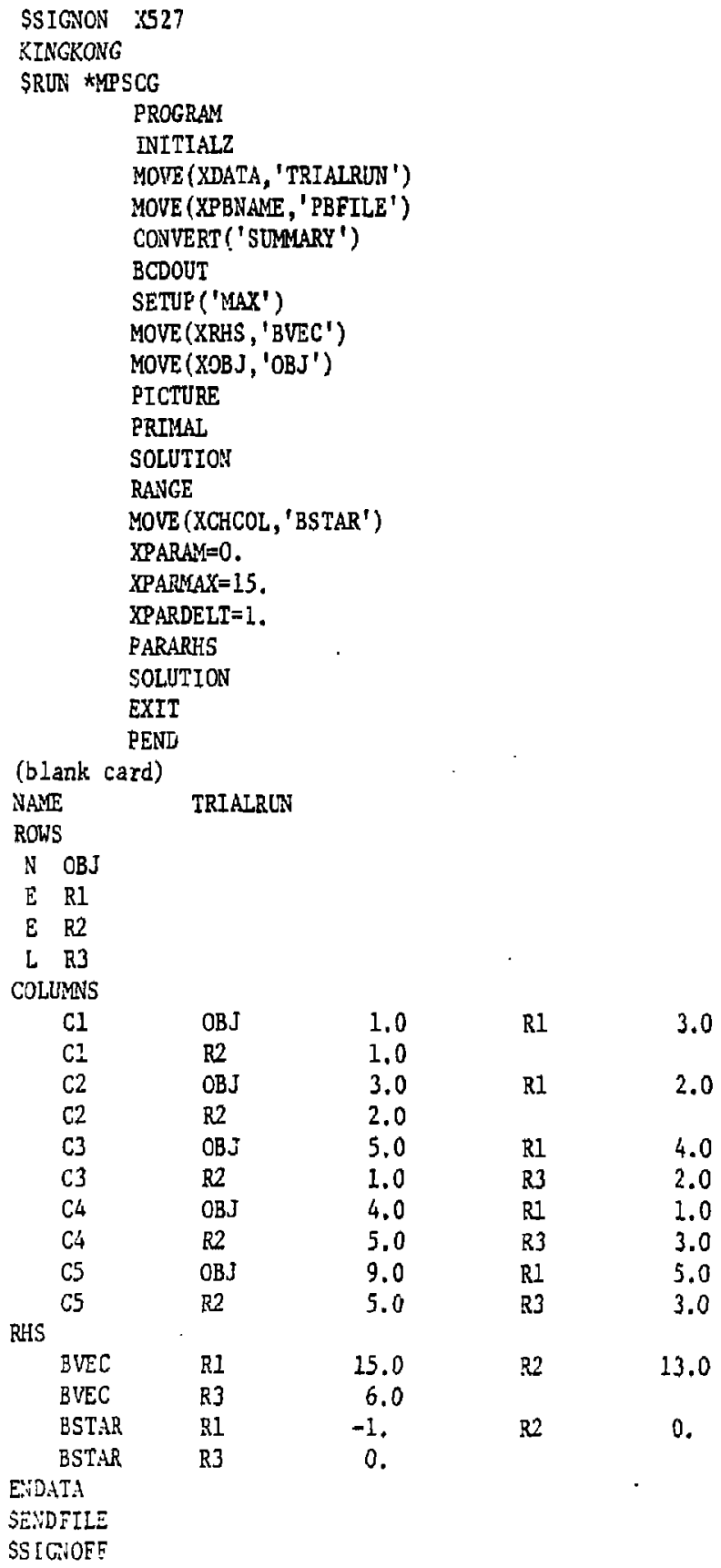




\section{H. INTERPRETATION OF OUTPUT FROM MPS}

\section{Commonly Used Statements}

(1) CONVERT--Execution of this statement yields the following output:

(a) Heading informacton--the procedure name, elạsed time, etc.

(b) A count of minor and major errors by section of the input data.

(c) A sumary of statistics for the model--number of rows, number of variables (including slack variables), the number of nonzero elements in the matrix, and the percentage of elements that are nonzero ("density").

If the 'SUMMARY' option is used, a page listing the tame of each column and the number of nonzero elements in the column, followed $b$; a page listing the name of each row and the number of nonzers elements in that row will be printed. (These two pages prerode the sumary listing). The column listing includes, at the far left of each line, the internal vector number of the first vi.tor on the line. Simllarly, the row listing includes, at the far left of each line, the internal nimber of the slack variable in the first row on the line.

(2) SETUP--Execution of this statement yields the following output:

(a) Heading information.

(b) A listing of the internal files to be used in the solution.

(c) A map of the data-storage area of memory.

(d) A sumary of problem statistics.

(3) PICTURE--Execution of this statement produces a condensed, coded "picture" of the current matrix. Each entry is given an alphabetic code depending on its magnitude, all columns and rows are labeled, and the type of constraint associated with each row is printed. A "key" to the alphavetic code follows this printout.

(4) PRIMAL--Execution of this statement produces the following output:

(a) The heading section, which specifits the nape of the procedure, the name of the objective Function and the right-hand side, and the elapsed time in the solution.

(b) An iteration Log of the steps in the solution during the stage from infeasibility to feasibility. The iteration number, the number of infeasibilities, the internal number of the outgoing vector, the jaternal number of the incoming vector, the reduced cost of the incoming vector, and the sum of the infeasibilities are specified.

(c) Notification when the feasible solution is determined,

(d) An iteration $\log$ of the steps in the solution, progressing from the feasible solution to an optinal (or unboundej) solution. The iceration numiter, ise muber of ncnop:ims? variables, the internai number of the ourgoing vector, the internal number of the incoming vector, the reduced cost of the incoming vector and the value of the functional are specified.

(e) Votification when an optimal (or unbounded) solution is reached. 
(5) SOLUTION--Execution of this statement outputs the current solution of the problem including the following three sections:

(a) The identification section provides the following output.

i. The status of the solution.

(1) INFEASIBLE

(2) NON-OPTIMAL

(3) OPTIMAL

ii. The time required by the LP program from the start of its execution to the start of the current procedure.

iii. The number of iterations (basis changes) performed so far.

iv. The name, activity level, and definition of each of the special rows and columns of the problem definition.

v. The names of the BOUNDS and RANGES vectors utilized (1f any).

(b) The Iow section.

(c) The colum section.

Each of these sections is printed as a table of elght columns, with one row of the table corresponding to each row or column of the problem. A description of these coluuns follows:

NMBER. The number of an internal logical variable associaced with the row-or column. If a work matrix contains on rows and $n$ column, the rows are numbered from 1 through $m$ and the colums are numbered from $(m+1)$ through $(m+n)$. These numbers are useful principally for analysis of the iteration log output which identifies vectors by their serial number.

ROW/COLUM. The eight-character name given to the row or column by the user.

AT. A two-character code indlcating the status of the row or colum (designated as an activity) in the solution:

BS - in the basis and feasible

** - in the basis and infeastble

FR - nonbasis free

EQ - nonbasis artificial or fixed

UL - nonbasis at upper limit

LL - nonbasis at lower limit

ACIIVITY. The value of the row or column in the current solution. For columns, this value is simply the value of the associated decision variable. For rows, this value is given by

$$
\sum_{j} a_{i j} x_{j}=b_{i}-I_{i}
$$

where $b=t_{1}$ a right-hand side and $l_{i}$ is the slack roriable for the $i^{\text {th }}$ constraint.

SLACK ACTIVITY/TNRUT COST. The slack activity is provided in the Row Section. The input cost is provided in the Column Section. 
IOWER IIMIT. The algeiraically lowest value that the activity can assume and still remain feasible.

UPPER LIMIT. The algebraically highest value that the activity can assume and still remain feasible.

DUAL ACTIVITT/REDUCED COST. The dual activity is provided in the Row Section and is generally known as the simplex multiplier. [The dual activity of a row is the reduced cost of the corresponding slack variable.] The reduced cost is provided in the Column Section. The reduced cost of a variable is the rate of increase in the objectiva function per unit increase in the variable.

If the optimal solution con:alns nonbasic variables with zero reduced cost, then alternate optima exist. Such variables are flagged in the priated tabulation.

The row and column sections of the SOLUTION output for the sample problem given in section $E$ are reproduced below to illustrate the interpretations of these sections.

ROWS

$\begin{array}{cccccccc}\text { Number } & \text { Row } & \text { At } & \text { Activity } & \begin{array}{c}\text { Slack } \\ \text { Activity }\end{array} & \begin{array}{c}\text { Lower } \\ \text { Limit }\end{array} & \begin{array}{c}\text { Upper } \\ \text { Limit }\end{array} & \begin{array}{c}\text { Dual } \\ \text { Activity }\end{array} \\ & \text { OBJ } & \text { BS } & 24.16667 & 24.16667- & \text { None } & \text { None } & 1.00000 \\ 2 & \text { RI } & \text { EQ } & 15.00000 & \ldots & 15.00000 & 15.00000 & .83333- \\ 3 & R 2 & \text { EQ } & 13.00000 & \ldots & 13.00000 & 13.00000 & .66667- \\ 4 & \text { R3 } & \text { UL } & 6.00000 & \ldots & \text { None } & 6.00000 & .50000-\end{array}$

The optinal value of the objective function is 24.16667 . The constraints corresponding to R1 and R2 are equalities (EQ), and hence the upper and lower limits for these rows are fixed. The fnequality constraint corresponding to R3 is at its upper limit (UL), and this activity could vary from 0 to 6 while still maintaining feasibility. The dual prices corresponding to the three constraints are $-.83333,-.66667$, and -.5000 respectively, and these indicate the race of increase of the objective function value per unit decrease in the values of the requirement vector (BVEC).

COLUMNS

\begin{tabular}{|c|c|c|c|c|c|c|c|}
\hline :umber & Columin & $\underline{A t}$ & Activity & $\begin{array}{l}\text { Input } \\
\text { Cose } \\
\end{array}$ & $\begin{array}{l}\text { Lower } \\
\text { Limic }\end{array}$ & $\begin{array}{l}\text { Upper } \\
\text { Limit } \\
\end{array}$ & $\begin{array}{c}\begin{array}{c}\text { Reduced } \\
\text { Cost }\end{array} \\
\end{array}$ \\
\hline 5 & $\mathrm{Cl}$ & LL & .. & 1.00000 & & None & $2.16667-$ \\
\hline 6 & $\mathrm{C} 2$ & $B S$ & 2.27778 & 3.00000 & . & None & $\cdots$ \\
\hline 7 & $\mathrm{C} 3$ & BS & .66667 & 5.00000 & $\cdots$ & Sone & $\cdots$ \\
\hline 8 & $C_{4}^{4}$ & LL & $\ldots$ & 4.00000 & $\cdots$ & None & $1.66667-$ \\
\hline 9 & C5 & Es & 1.55556 & 9.00000 & $\cdots$ & None & $\ldots$ \\
\hline
\end{tabular}

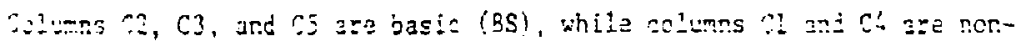
busic at their loner limit (LL) of zero. Hence the optimal program is $x_{1}=0$, $x_{2}=2.27793, x_{3}=.60667, x_{4}=0$, and $x_{5}=1.55556$. No upper or lower Feasibilicy

linits are given for the columns, since the decision varlables were only constrained to be non-negative. The reduced costs of variables $x_{1}$ and $x_{3}$ are 
-2.16667 and -1.66667 respectively, and these indicate the rate of increase in the objective function value per unt increase in these varfables.

\section{Postoptimality Statements}

(1) RANGE--This statement produces 5 sections of output:

(a) Identification--elapsed time of the run, number of iterations, etc.

(b) Activity--value relationships for constraint rows at limit level. (constraints which are "tight")

(c) Activity--value relationsiins for constraint rows at intermediate level. (constraints which are not binding at optinality)

(d) Price--activity cost relatlonships for structural varlables (columns) at limit level. (at their upper or lower bounds)

(e) Price--activity--cost relationship for structural varfables (columns) at intermediate level.

Selected portions of Sections (b) through (d) of the RANGE output for the sample problem given in Section $G$ are reproduced below to 1llustrate the incerpretations of these sections.

\begin{tabular}{|c|c|c|c|c|c|c|}
\hline Row & Activity & $\begin{array}{l}\text { Lower Limit } \\
\text { bpper Limit }\end{array}$ & $\begin{array}{l}\text { Lower Activity } \\
\text { Upper Activity }\end{array}$ & $\begin{array}{l}\text { Unit } \\
\text { Cost }\end{array}$ & $\begin{array}{l}\text { Upper Cost } \\
\text { Lower Cost } \\
\end{array}$ & $\begin{array}{l}\text { Limfiting } \\
\text { Process }\end{array}$ \\
\hline & & 15.00 & 13.00 & $.83-$ & & G3 \\
\hline RI & 15.00 & 15.00 & 22.00 & .83 & . & $\mathrm{C} 5$ \\
\hline & & 13.00 & 6.00 & $.67-$ & & $\mathrm{C5}$ \\
\hline R2 & 13.00 & 13.00 & 15,00 & .67 & .. & C3 \\
\hline & & None & 1.33 & .50 & & C5 \\
\hline R3 & 6.00 & 6.00 & 8.73 & .50 & .. & $C 2$ \\
\hline
\end{tabular}

For instance, the right hand side of the first constraint can range from 13.00 to 22.00 while the current optimal basis is st1ll maintained. For this range of values the rate of increase in the value of the objective function per unit increase in the RHS is .83 . For values of the right hand side below 13.00 column $\mathrm{C} 3$ leaves the basis, and for values of the right hand stde above 22.00 column $\mathrm{C5}$ leaves the basis.

\section{COLLMS AT LDIT LEVEL}

Lower Limit Lower Activity Unit Upper Cost Limiting Column Activity Joper inint gpper Activity Cost Lower Cost Process At

$\begin{array}{cccccccc} & & \ldots & 3.50- & 2.17 & \text { Infinity- } & \text { C5 } & \text { LL } \\ \text { C1 } & \ldots & \text { i.one } & 1.00 & 2.17- & 3.17 & \text { C3 } & \text { LL } \\ & & \ldots & .50- & 1.67 & \text { Infinity- } & \text { C3 } & \text { LL } \\ \text { C4 } & \ldots & \text { Wone } & .82 & 1.67- & 5.67 & C 5 & \text { LL }\end{array}$


For instance, if the unit input cost of $C 4$ is recuced from 4 to $-x$, $C^{\prime}+$ will enter the optimal solution at a level of -.50 (ignoring the non-nagativity restriction). If the unit input cost of $C 4$ is increased from 4 to 5.67 , C4 will enter the optimal solution at a level of .82 , replacing $C 5$ in the basis. For the original problem, the rate of decrease in the objective per unit increase in the level of $\mathrm{C} 4$ is -1.67 (the reduced cost of the non-basic column $\mathrm{C} 4$ ).

\section{ROWS AT INTERMEDIATE LEVEL}

(For the sample problem, no rows are at an intermediate level.) COLLMINS AT INTERUEDIATE LEVEL

\begin{tabular}{|c|c|c|c|c|c|c|}
\hline columar & dctivity & $\begin{array}{l}\text { Lower Limit } \\
\text { Upper Limit }\end{array}$ & $\begin{array}{l}\text { Lower Activity } \\
\text { Upper Activity }\end{array}$ & $\begin{array}{l}\text { Unit } \\
\text { Cost } \\
\end{array}$ & $\begin{array}{l}\text { Upper Cost } \\
\text { Lower Cost } \\
\end{array}$ & $\begin{array}{r}\text { Liniting } \\
\text { Process } \\
\end{array}$ \\
\hline & & & 1.00 & $1.70-$ & 1.30 & $\mathrm{Cl}$ \\
\hline $\mathrm{C} 2$ & 2.28 & None & 6.17 & .60 & 3.60 & 83 \\
\hline & & $\cdots$ & $.52-$ & $3.25-$ & 1.75 & $C I$ \\
\hline C3 & .67 & None & 1.76 & $1.25-$ & 6.25 & $C_{4}$ \\
\hline & & .. & Infinity- & & 8.12 & $\mathrm{CH}$ \\
\hline C5 & 1.56 & None & 2.00 & 4.88 & 13.88 & $\mathrm{Cl}$ \\
\hline
\end{tabular}

For instance, if the unit input cost of $\mathrm{C} 2$ is reduced from 3 to 1.30 , C2 wi11 be reduced to a level of 1.00 . The rate of decrease of the objective function per unit decrease in $\mathrm{C} 2$ will be 1.70 . Further decreases in the input cost of $\mathrm{C} 2$ will result in non-basic column $\mathrm{C} 1$ entering the optimal basis.

If the unit input cost of $\mathrm{C} 2$ is increased to $3.50, \mathrm{C} 2$ will be increased to a level of 6.17 in an optimal solution. The rate of increase in the objective iunction per unit increase of $\mathrm{C} 2$ will be .60 . Further increases in the unit cost of $C 2$ will not result in a change of the level of $\mathrm{C} 2$, since constraint R3 is binding for the resulting optimal solution when $\mathrm{C} 2$ is at a level of 6.17 .

(2) PARARHS-This statement function produces an iteration $10 \mathrm{~g}$ giving the value of the objective and the parameter at basis changes, and prints one of the following three messages upon completion:

(a) "Yaximum of Parameter"--The parameter is at its maximum value (XPARMAX).

(b) "Prenature Maximum"--The problem becomes infeasible at the current value of the parameter. No further basis change can occur.

(c) "Vo Maximum for Parameter"--The parameter has reached a value beyond which it can be increased indefinitely wichout requiring a basis change to maincain feasibility.

(3) PAFARI:--This statement produces an output with fomat almost identical to PARARES. If the problem becomes infeasible or unbounded, the solution is kept at the optimal and feasible value attained immediately betore termination of PARARIM. If there is "no maximum for the paramete:," the parameter is set equal to XPARMAX, and the solution is brought up to this value.

(6) PARACOL--This statement produces an output with format identical to that produced by PARARTY. 
(5) EARAROW-This statement produces an output with format identical to that produced by PARARIM.

(6) PARAOBJ--This statement produces an output with format 1dentical to that produced by PARARHS.

"Work performed under the auspices of the U.S. Depastment of Energy by the Lawrence Livermote Laboratory under contract number W.7405-ENG.48."

Reference to a company or product name does not imply approval or recommendation of the product by the University of Callifornia or the U.S. Department of Energy to the exclusion of others that may be suituble.

\section{NOTICE}

"This teport was prepared as an account of work sponsored by the United Staies Government Neither the United Stales nor the Uniled States Department of Energy, nor any of their emplayees, nor any of their contraclors, subcontractors, or their employees, makes any warranty, express or implied, or assumes any legal liability or responsibility for the accuracy, completeness or usefulness of any information, apparatus, producl or process disclosed, or represents that its use would not ińtinge privately-owned rights." 
APPENDIX A7

PROGRAM LISTINGS

\section{COMMAND FILES}

FILE NAME: DATAl, DATA2, DATA3, DATA4

START, SETUP, RUNLP, SCAN2, INFEAS

MESSAGE

\section{PERMANENT FILES}

PILE NANE: COMMANDS

MAX, MIN, END

RULEROWS, RULESRHS

EXRULES

TYPEILE

TYPROWS

S.SETUP

IEMPORARY FILES

FILE IAME: $-F 2,-F 3,-F 8,-F ?$

$-57$ 


\section{COMMAND FILES}

\section{FILE NAME: DATA1}

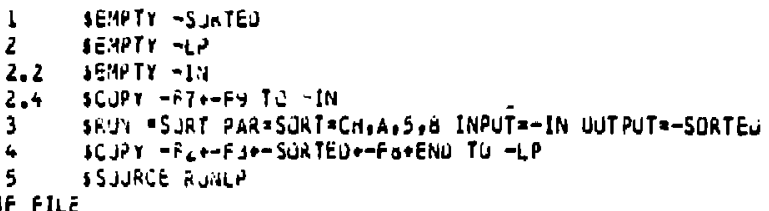

\section{FILE NAME: DATA2}

1 SEAPTY S SnTES

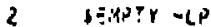

L.S DETTI -11

2.4 SCJPY - F Th-FY+EXRULLES TO - IA

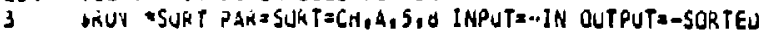

$\rightarrow \quad J C J P Y-+Z$ ZRULEROAS+-F3+-SUKTED+-FO+RULESRHS+ENU TO -LP EHO UF FILE SSUWRCE RUIMLP

\section{FILE NAME: DATA3}

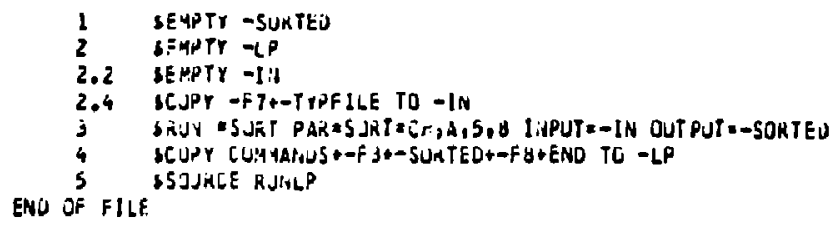

\section{FILE NAME: DATA4}

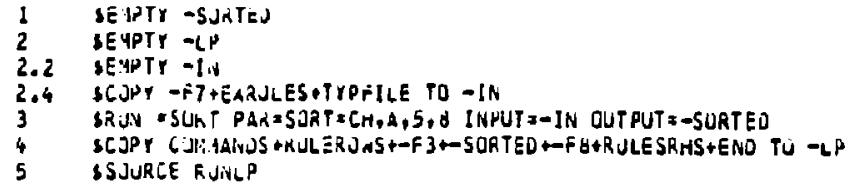




\title{
COMMAND FILES
}

\section{FILE NAME: START}

\author{
END. OF FILE \\ SSET ECHIUSDFF \\ SCOPY MESSAGE $(1,3)$
}

\section{FILE NAME: SETUP}

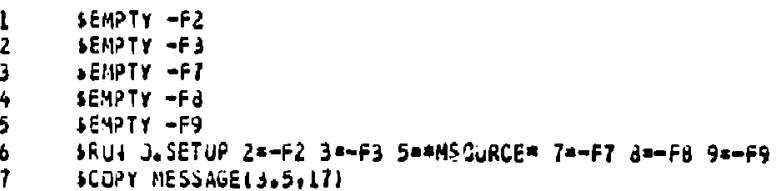

\section{FILE NAME: RUNLP}

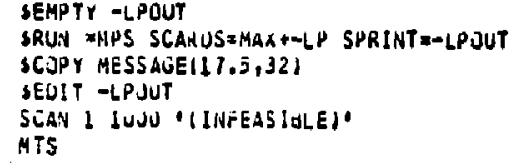

ENO OF FILE

\section{FILE NAME: SCAN2}

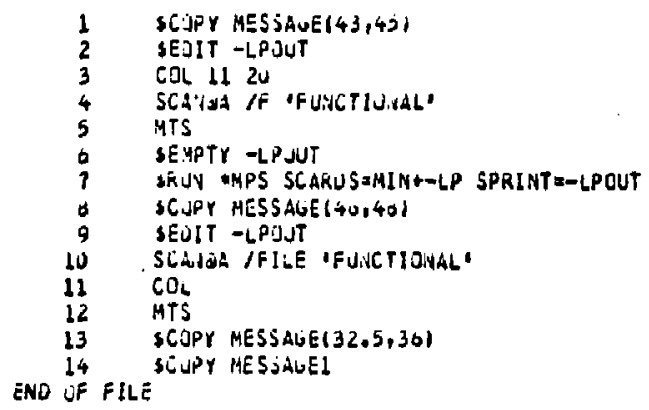

\section{FILE NAME: INFEAS}

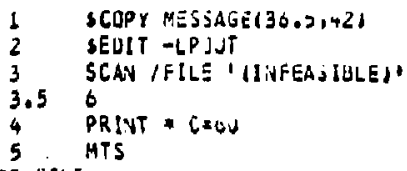


COMMAND FILES

FILE NAME: MESSAGE

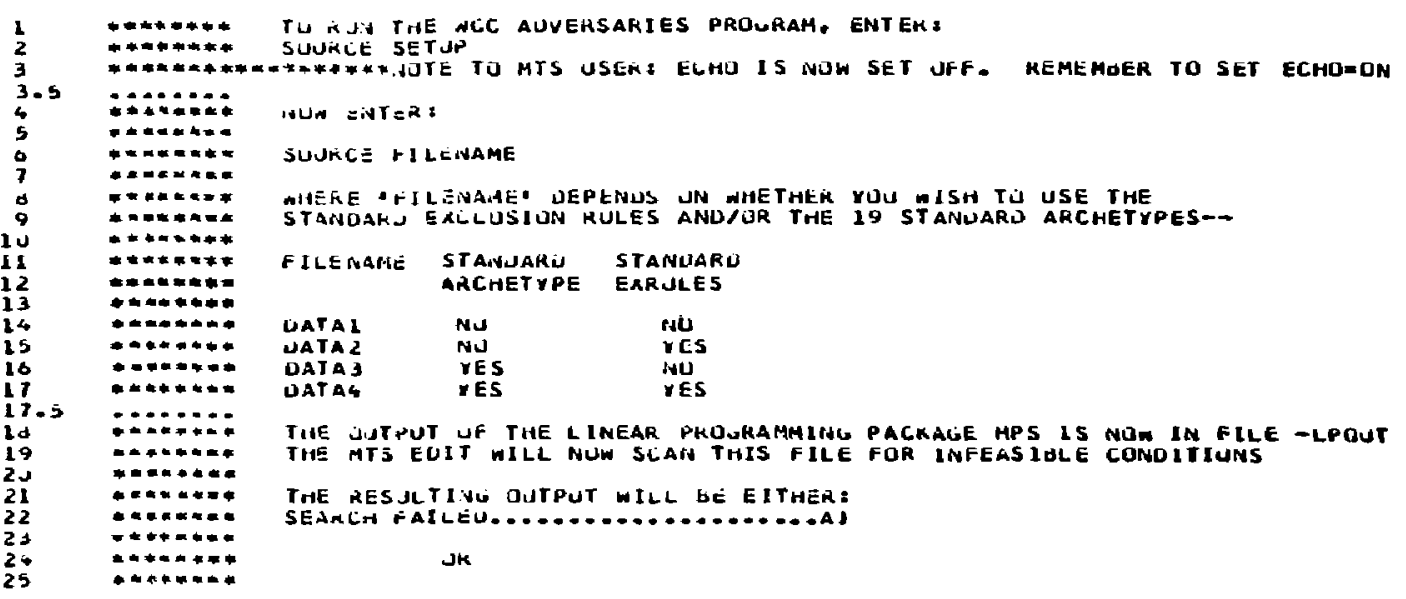




\section{FILE NAME: MESSAGE (continued)}

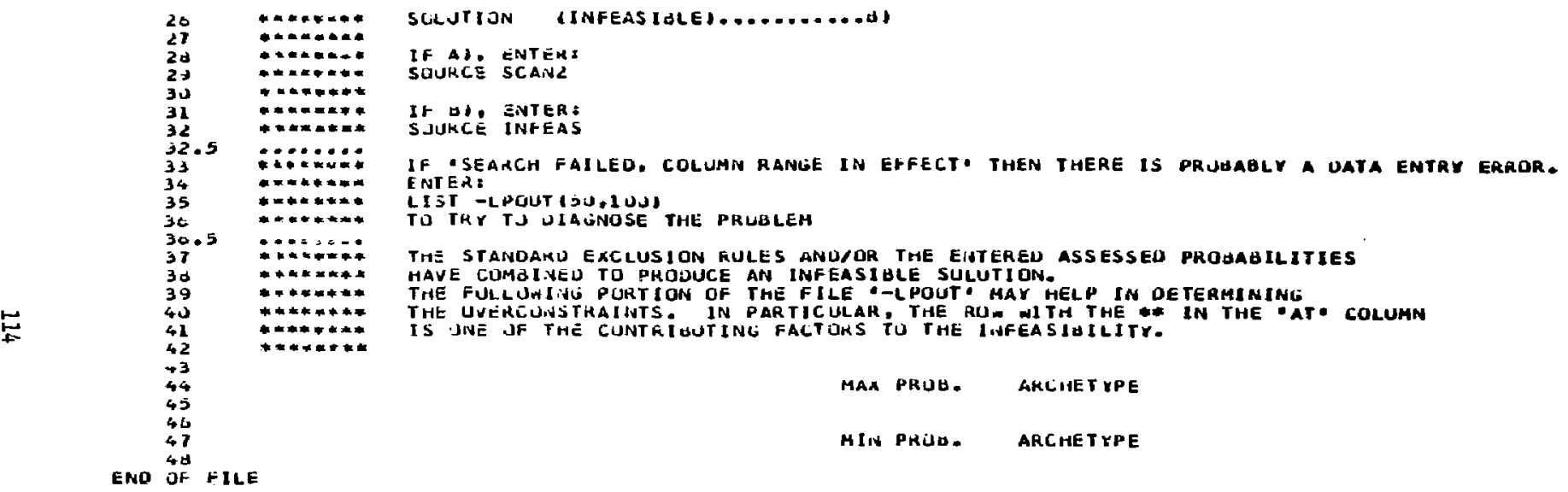


PERMANENT FILES

\section{FILE NAME: COMMANDS}

\begin{tabular}{|c|c|}
\hline 8.5 & 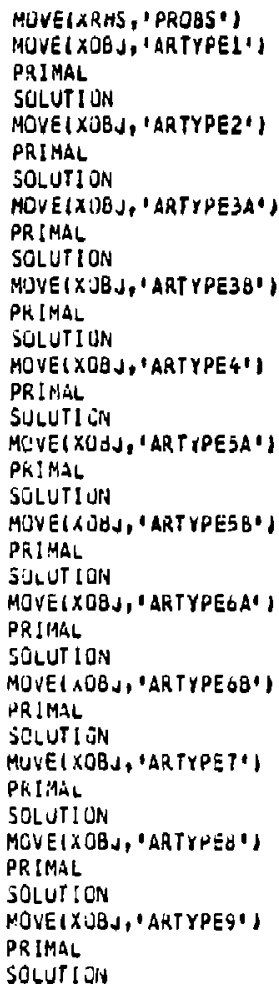 \\
\hline
\end{tabular}




\section{FILE NAME: COMMANDS (continusd)}

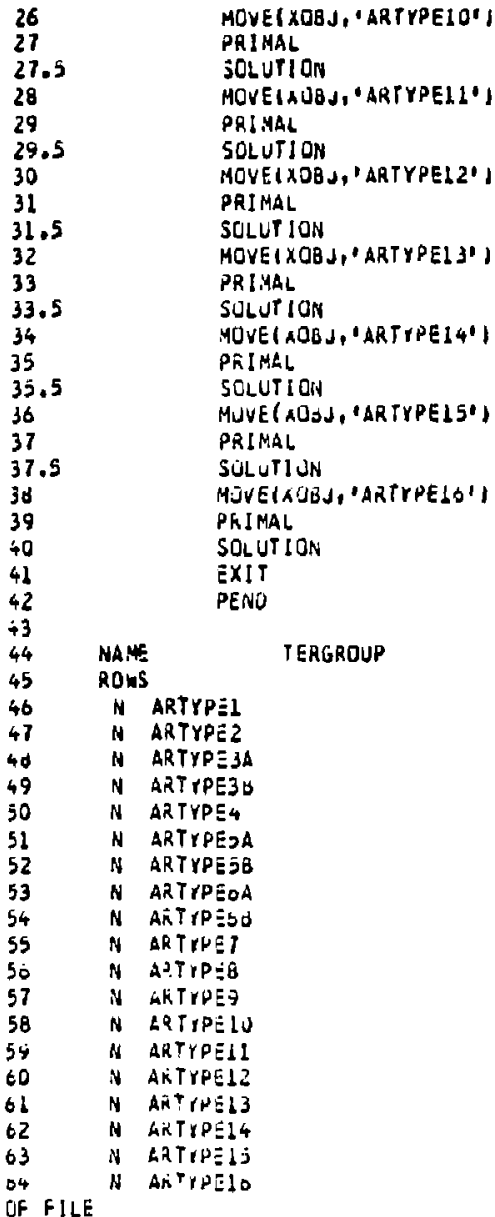




\section{PERMANENT FILES}

\section{FILE NAME: MAX}

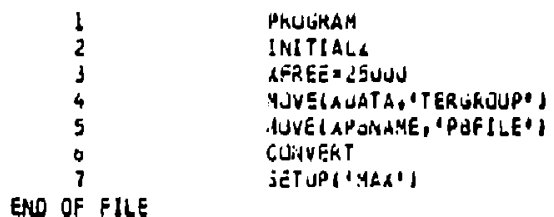

\section{FILE NAME: MIN}

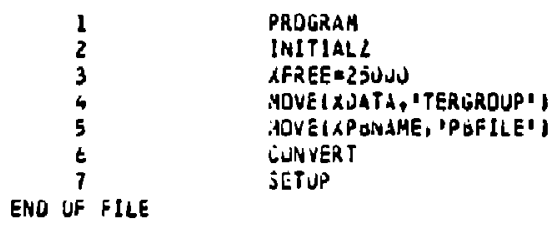

\section{FILE NAME: END}

ENO OF FILE

1 ENUATA

ENU OF FILE 


\section{PERMANENT FILES}

FILE NAME: RULEROWS

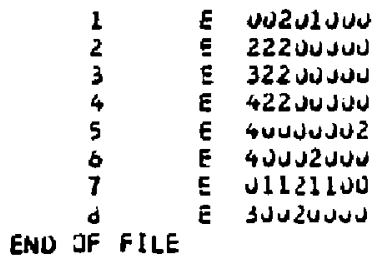

\section{FILE NAME: RULESRHS}

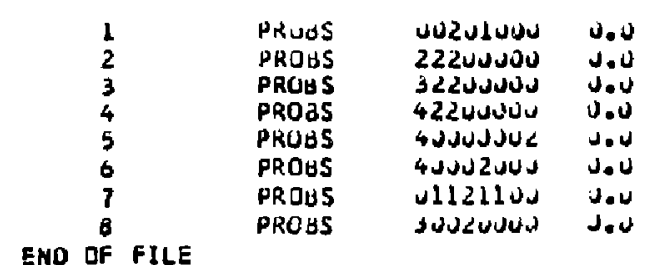




\section{PERMANENT FILES}

\section{FILE NAME: EXRULES}

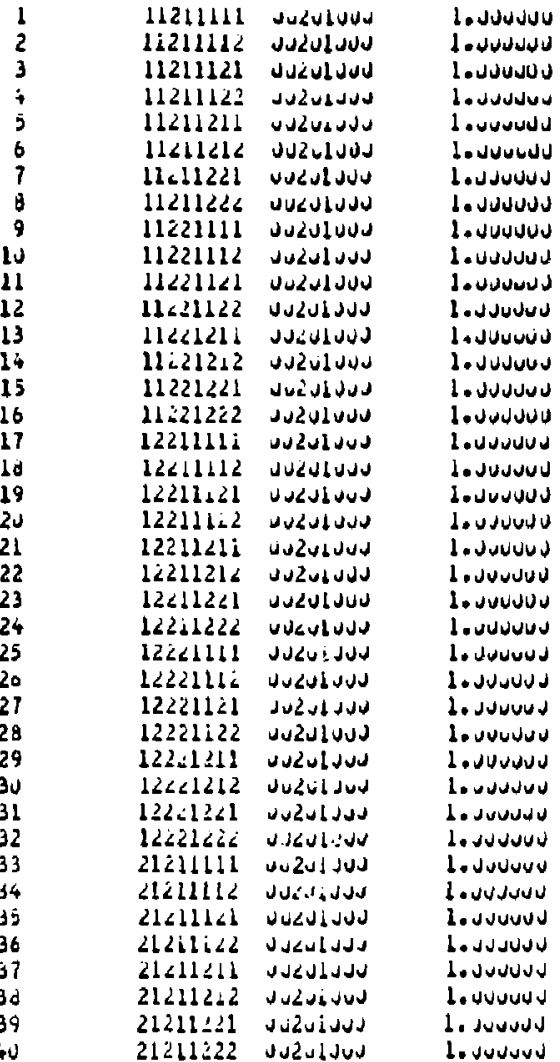


FILE NAME: EXAULES (continued)

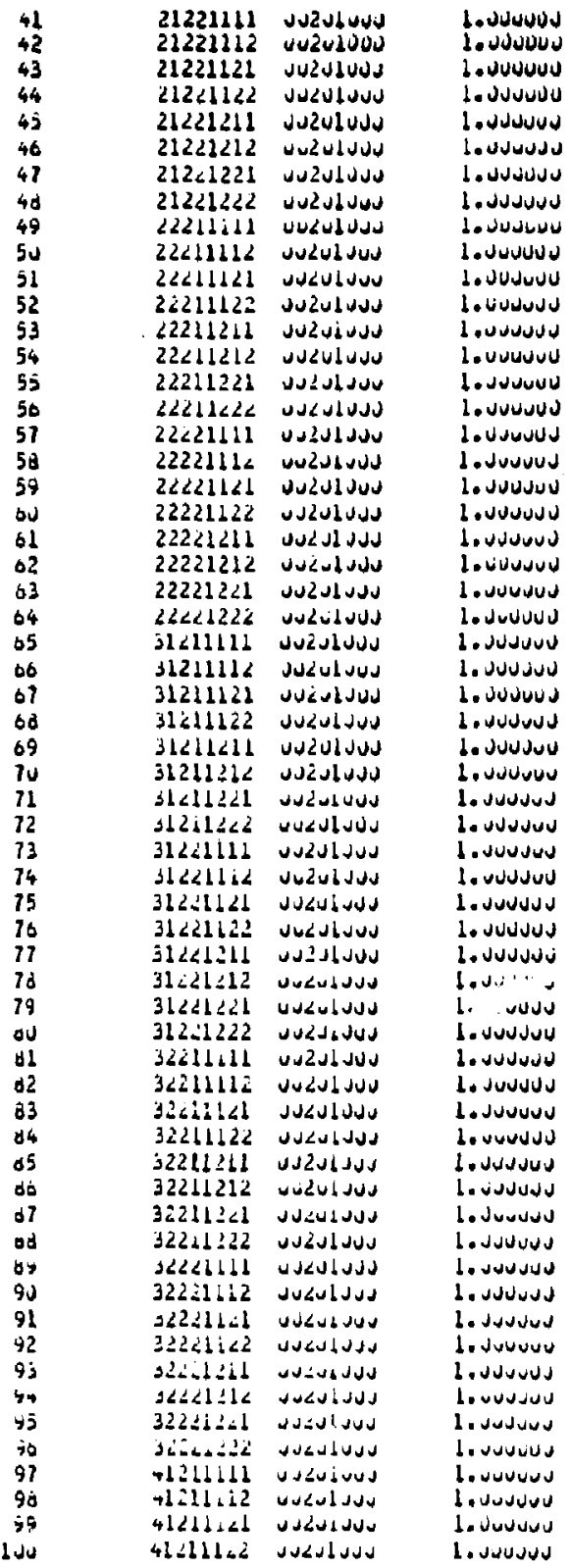


FILE NAME: EXRULES (continued)

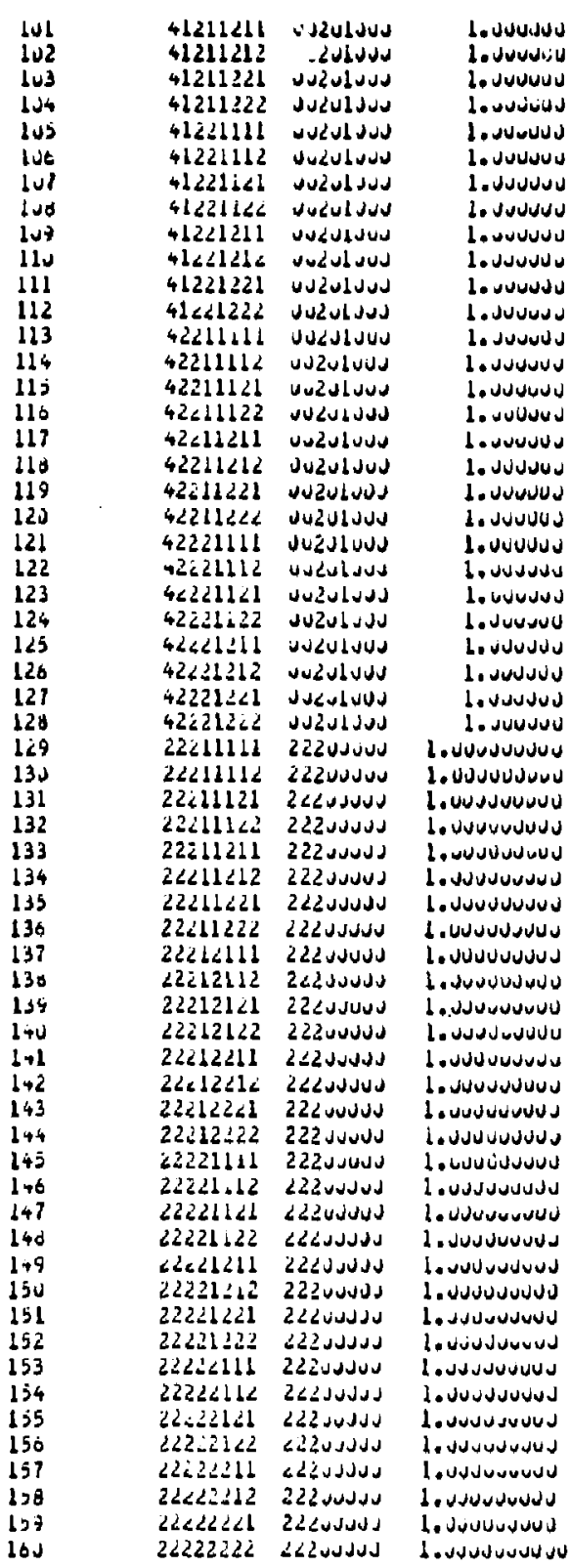


FILE NAME: EXRULES (continued)

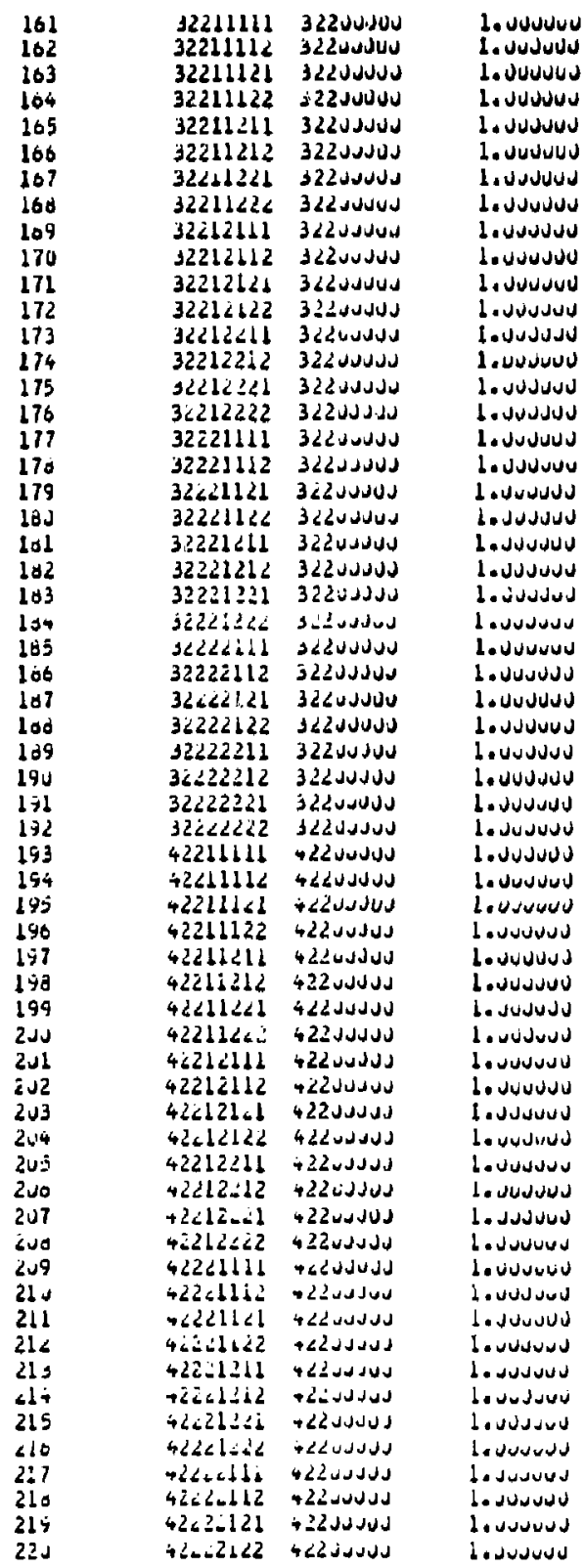




\section{FILE NAME: EXRULES (continued)}

\begin{tabular}{|c|c|c|c|}
\hline $\begin{array}{l}221 \\
222 \\
225 \\
224\end{array}$ & $\begin{array}{l}+2622211 \\
42<42412 \\
422<2221 \\
+2222262\end{array}$ & 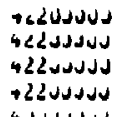 & 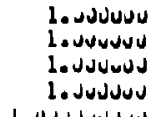 \\
\hline$\angle 25$ & +1111112 & CJNJIJNL & d. UUUJuJJuJ \\
\hline 220 & +1111126 & - JuUJude & 1. טUJuJuJuJ \\
\hline 227 & $+11+1312$ & 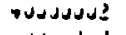 & 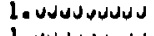 \\
\hline 2as & $7+111262$ & 4 & l. UuUsuJous \\
\hline 227 & $+111-116$ & 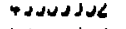 & 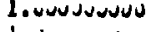 \\
\hline Csu & $+11121<2$ & 4งปJuJue & La dusurusuara \\
\hline 231 & $4111<21-$ & 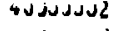 & 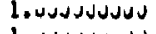 \\
\hline 232 & +1112222 & +ง JuدJงL & 1. UUvUJuUdu \\
\hline 233 & +1121112 & +UJJנJUL & 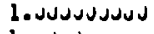 \\
\hline 234 & +llरllik & † บงปปJJL & d. susjuusuas \\
\hline 235 & 41121264 & TJadvuJs & 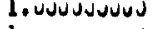 \\
\hline 220 & 41121222 & 4 JปدJJעL & L. UUJu vuJus \\
\hline 237 & $-112<112$ & 4uJuvJuJL & 1. UUdJuJJuJ \\
\hline 236 & $411+3123$ & - ปปปปปปน & 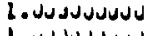 \\
\hline 239 & $+1122: 12$ & 4 jJuJJude & 1. UJJuJJuUJ \\
\hline $2+4$ & 41122222 & + JUلJud? & 1. UJudunued \\
\hline $2+1$ & $412 l_{2}: 12$ & 4uJงuงv2 & L.JuUsJusus \\
\hline 242 & $412111<6$ & 4uJusuve & 1. avosuavios \\
\hline 243 & 41211112 & 4 JUUJJปL & 1 . UJJJUVUUU \\
\hline 244 & 41211222 & 4uJuJudse & 1. UNU JUUSUJ \\
\hline 245 & 41212112 & + JuUvงudL & 1. UUJujuJuUJ \\
\hline 240 & 41212122 & ๑ ปภงปJง2 & 1. JjiesuJusu \\
\hline 247 & 41212416 & 4ن่JUjJJL & 1. UJuUNJUN \\
\hline 240 & 41212222 & 4 & 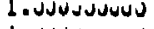 \\
\hline 247 & $4122111<$ & iUงuงuJuL & 1. ojusjusugas \\
\hline $25 \mathrm{~s}$ & 41221122 & 4UJUJJu? & b.UJdJuJuUJ \\
\hline 231 & 41221216 & 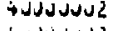 & l. unuvuJuuv \\
\hline $2 j 2$ & 41221222 & tuvúvud? & 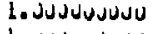 \\
\hline 253 & $412 \therefore<114$ & fuUuJJus & L.VUJuJJuUS \\
\hline 254 & $412221<2$ & † +jJuJJud & 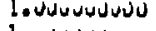 \\
\hline 255 & +1222612 & 4UJUปدJ2 & 1.uJuJuduvu \\
\hline $2 j 0$ & 41622322 & 4UJuJJuL & 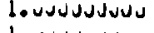 \\
\hline 257 & 42111112 & TuJusuva: & 1. บUudusuvu \\
\hline 208 & $+21111 \mathrm{~L}$ & 4uJuUuJue & L. susjuusuosu \\
\hline 253 & +2111216 & 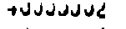 & 1. uvusursusio \\
\hline $2 \varepsilon v$ & 421111232 & 4 JUUUدUL & l.uJuJusuus \\
\hline 261 & $42114 i 16$ & T JUUJJUL & 1. vugungudus \\
\hline 202 & $4<1121<2$ & i JusuguL & 1. Uduvosudus \\
\hline $2 \notin 3$ & 42112212 & 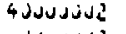 & 1. JJưvJJuJ \\
\hline 204 & 42112ict & PJJUAJd2 & 1. JJJuvטJuJ \\
\hline 205 & $4 \leq 1 \geq 1112$ & + ภงปレンปL & 1. avoudasuas \\
\hline 200 & $4 \angle 1<1<22$ & 4०JudJuL & L. JJuUduJugu \\
\hline ¿c7 & $42121<i 2$ & 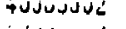 & 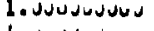 \\
\hline 200 & $+21=1222$ & + UJJuJuL & Iovusulusaras \\
\hline 204 & $+212: i j 2$ & PUjuงudz & 1. unusudiusu \\
\hline 27. & $96 b 22 i 22$ & 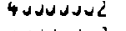 & I. uvusuuduv \\
\hline 271 & $42 b<\leq<12$ & +uงvuviv2 & 1. uduusudus \\
\hline 272 & $4<1<22-2$ & +UJuJddJ? & 1. usuusuasus \\
\hline 673 & $422111+2$ & "TJuJuse & La usuuguavor \\
\hline 274 & $111: 2$ & 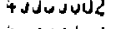 & L. vusunuvus \\
\hline 275 & 11212 & iudusJus & 1. 0usunusuas \\
\hline 470 & 11262 & iJuUdudL & 1. vUưJJurd \\
\hline 271 & $42-2116$ & 4 UUUduve & 1. JJuJusuga \\
\hline 27 & +2212122 & T Jปบuงde & 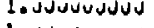 \\
\hline 27 & $4.21<212$ & 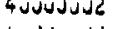 & Lo Juvidusudu \\
\hline 20 & 42216 & 4 UلปJu & 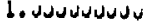 \\
\hline
\end{tabular}


FILE NAME: EXRULES (continued)

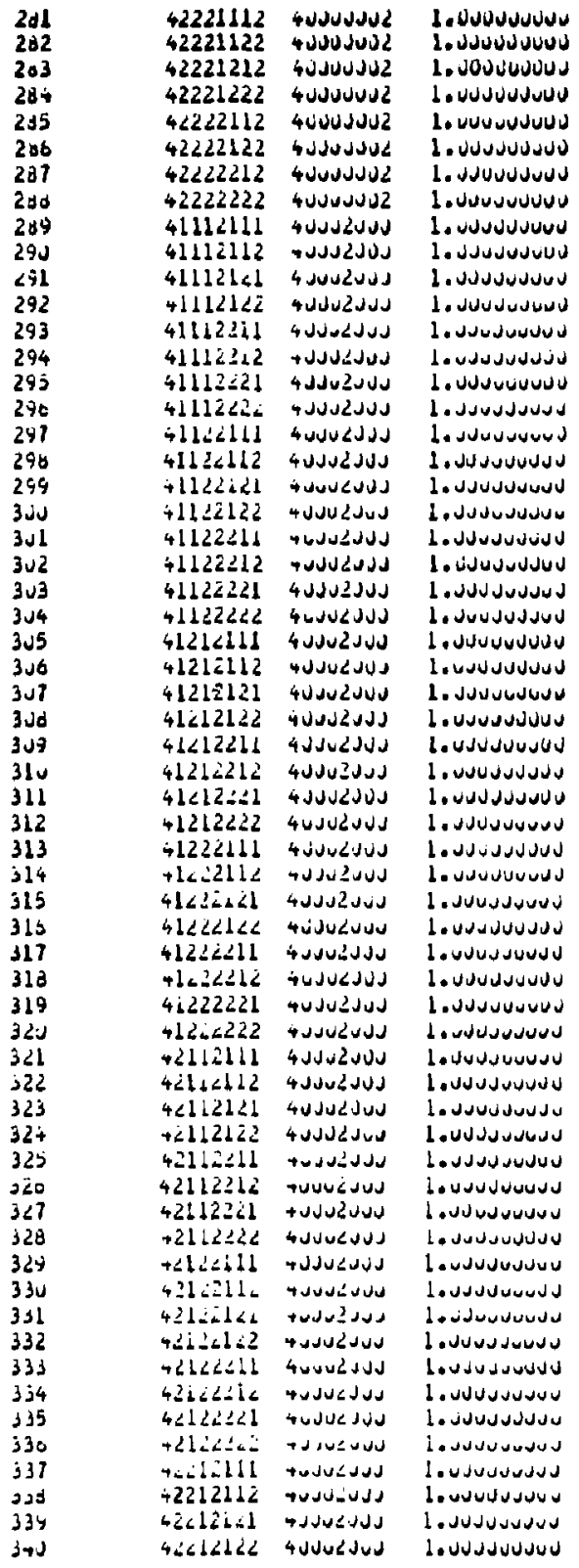




\section{FILE NAME: EXRULES (continued)}

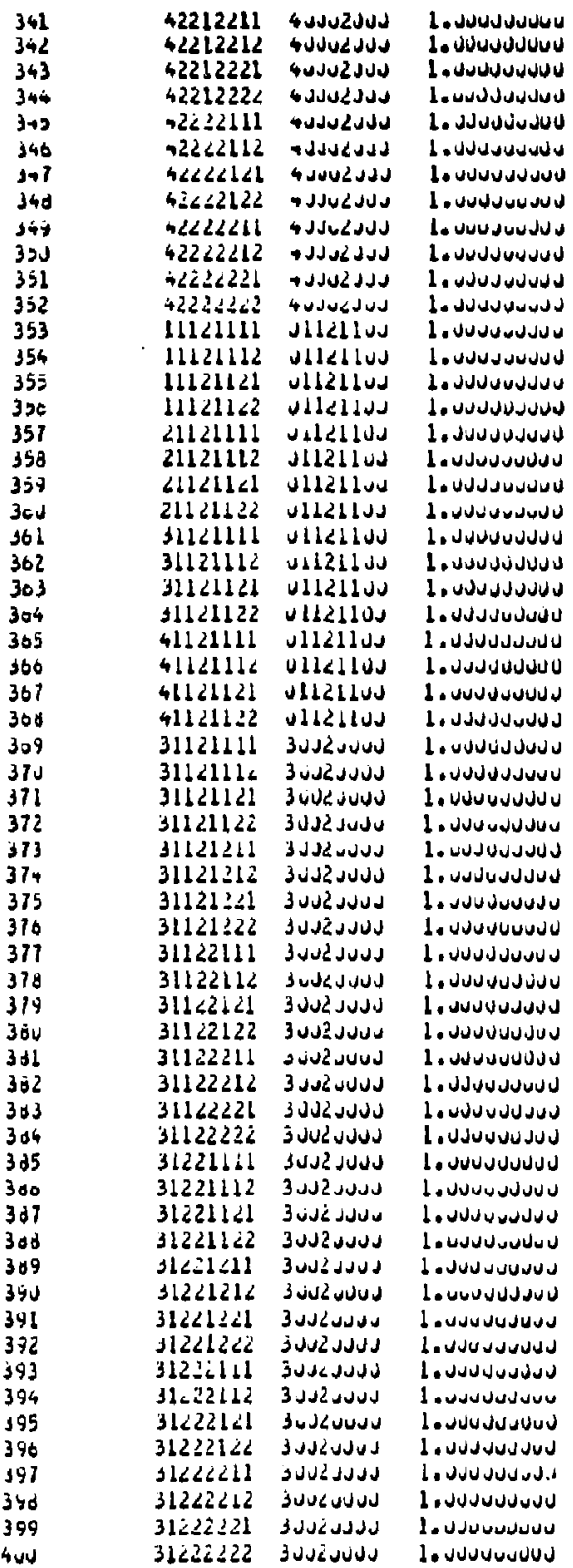


FILE NAME: EXRULES (continued)

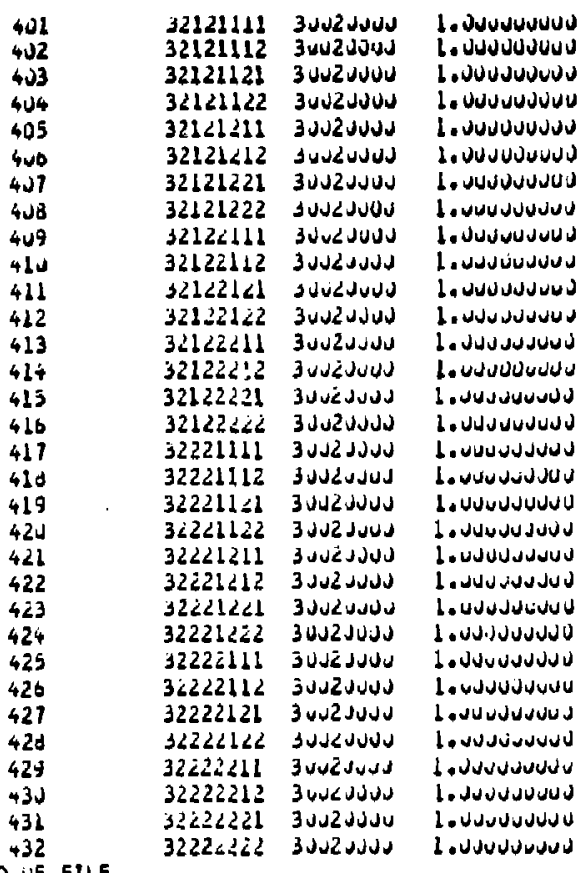




\section{PERMANENT FILES}

\section{FILE NAME: TYPFILE}

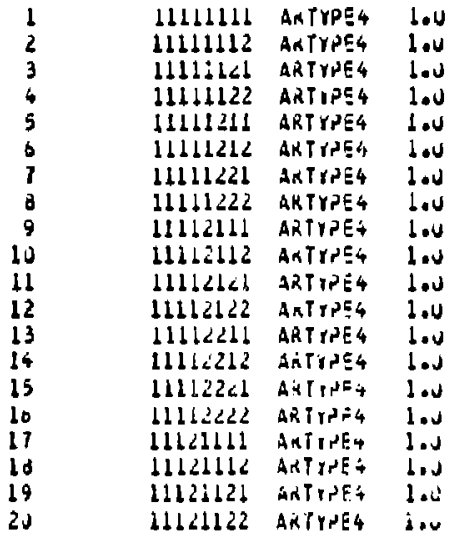


FII.E NAME: TYPFILE (continued)

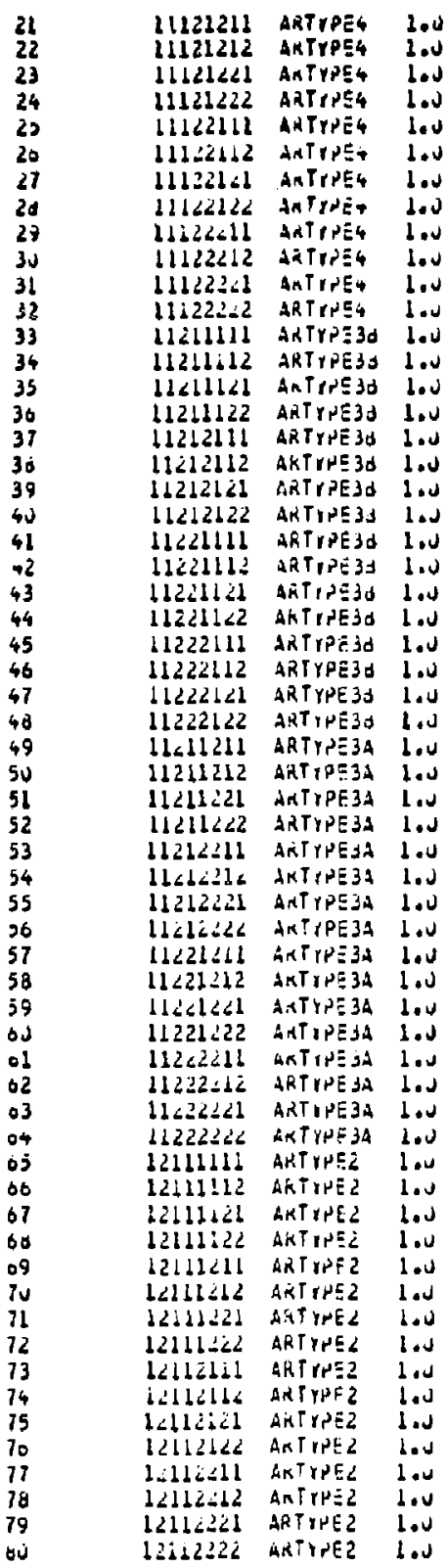


FILE NAME: TYPFILE (continued)

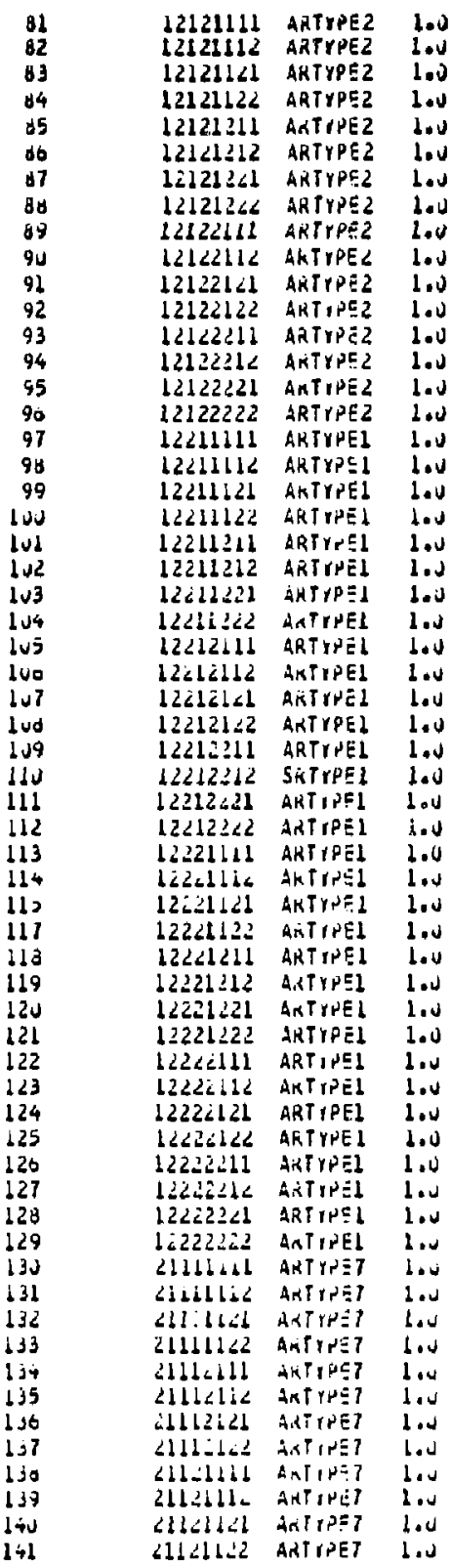


FILE NAME: TYPFILE (continued)

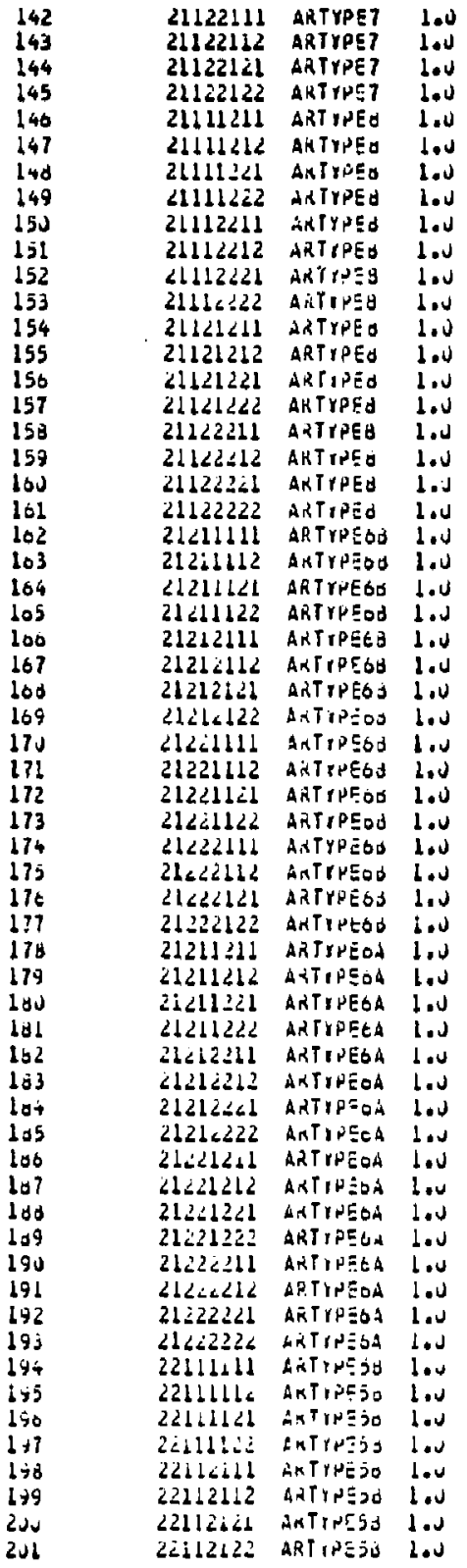


FILE NAME: TYPFILE (continued)

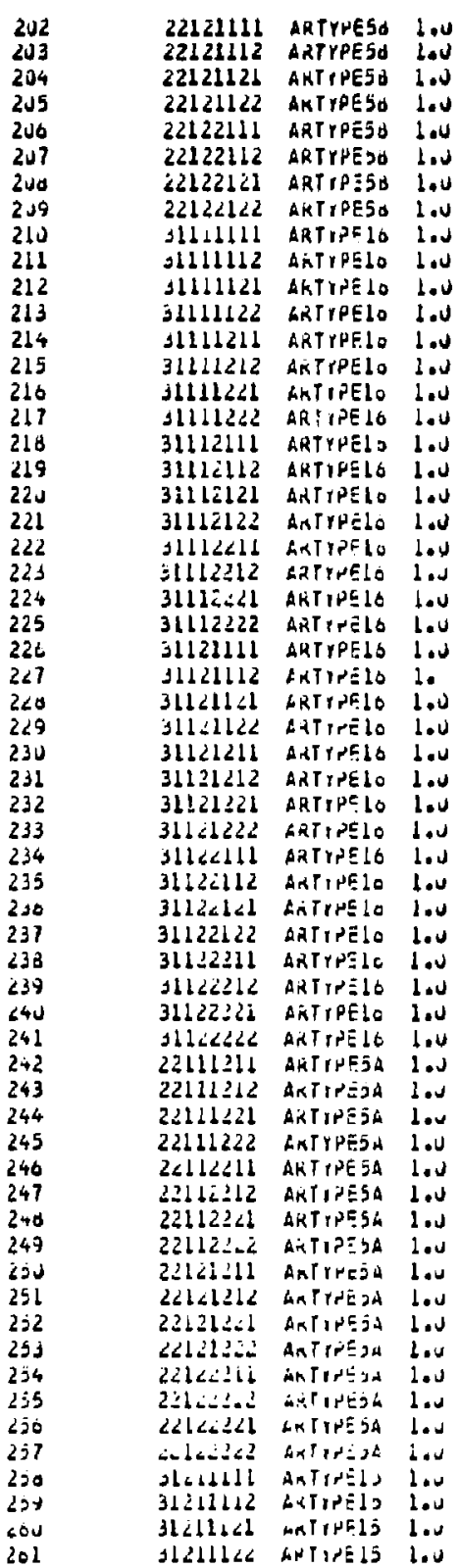


FILE NAME: TYPFILE (continued)

\begin{tabular}{|c|c|c|}
\hline 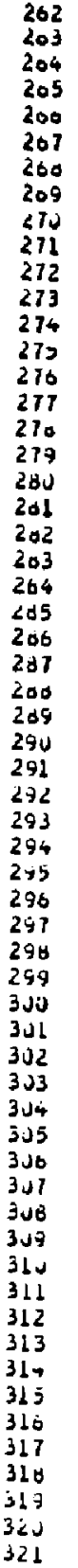 & 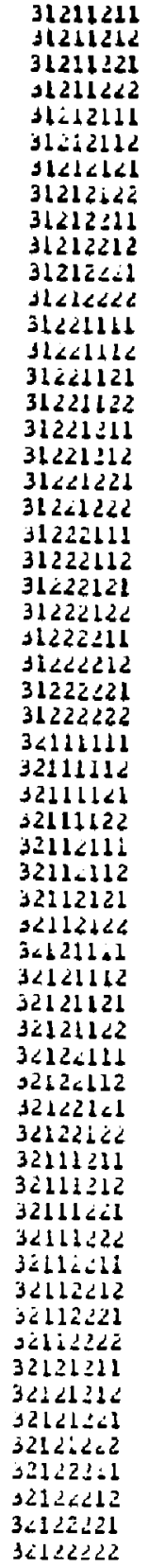 & 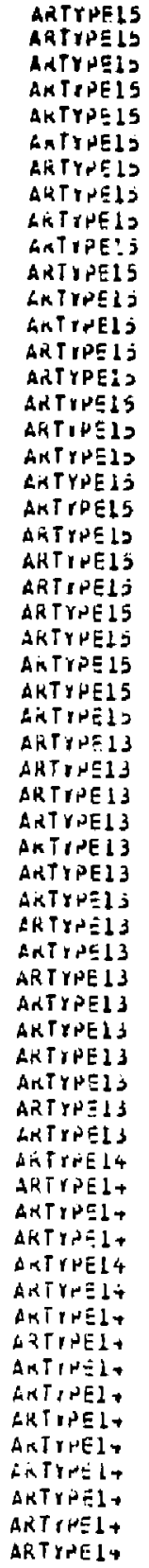 \\
\hline
\end{tabular}


FILE NAME: TYPFILE (continued)

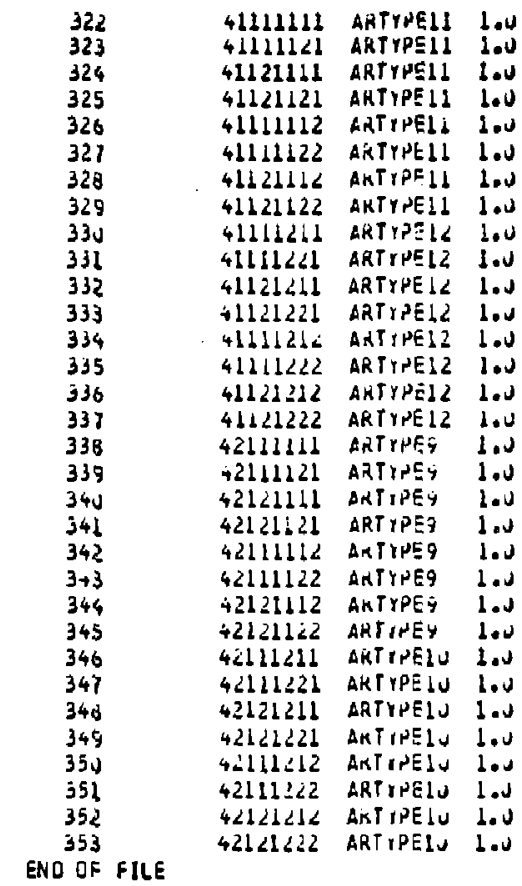




\section{PERMANENT FILES}

FILE NAME: TYPROWS

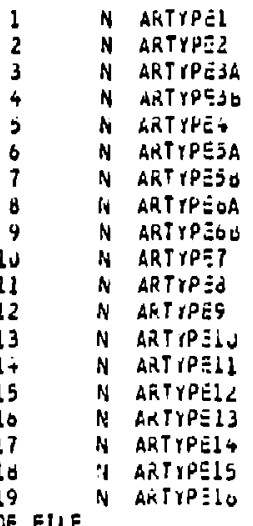

KND SF FILE 


\section{PERMANENT FILES}

\section{FILE NAME: S.SETUP}

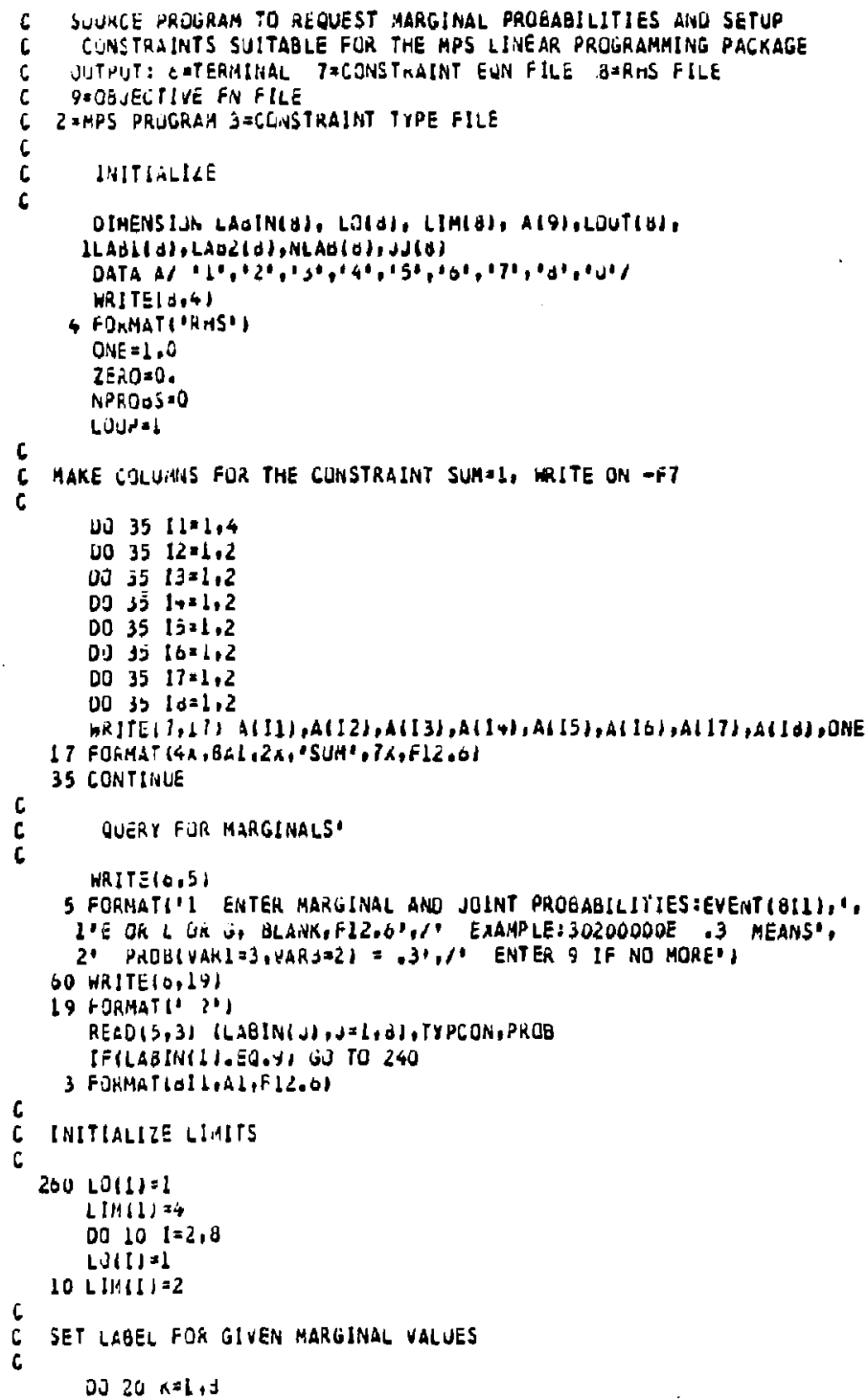




\section{FILE NAME: S.SETUP (continued)}

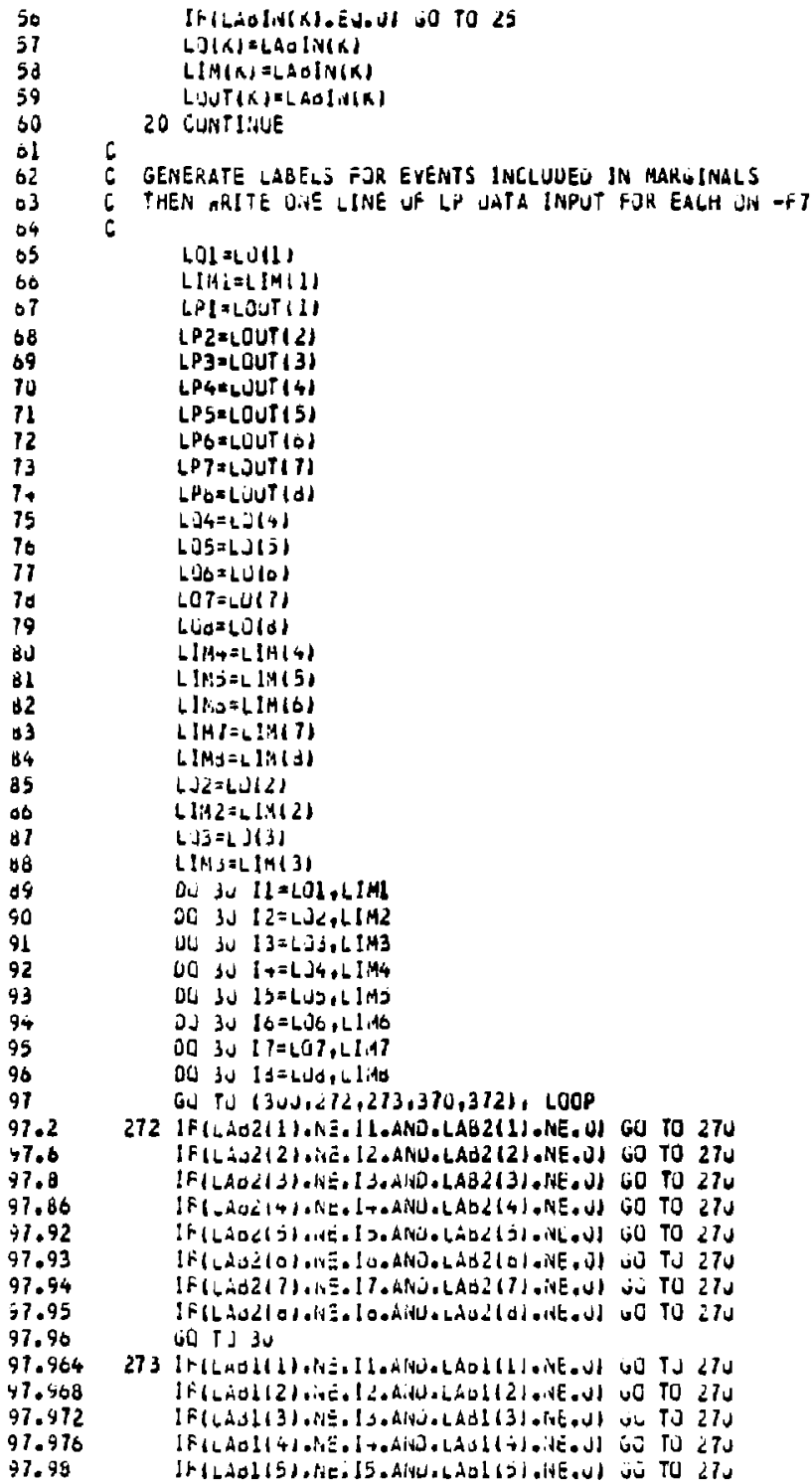


FILE NAME: S.SETUP (continued)

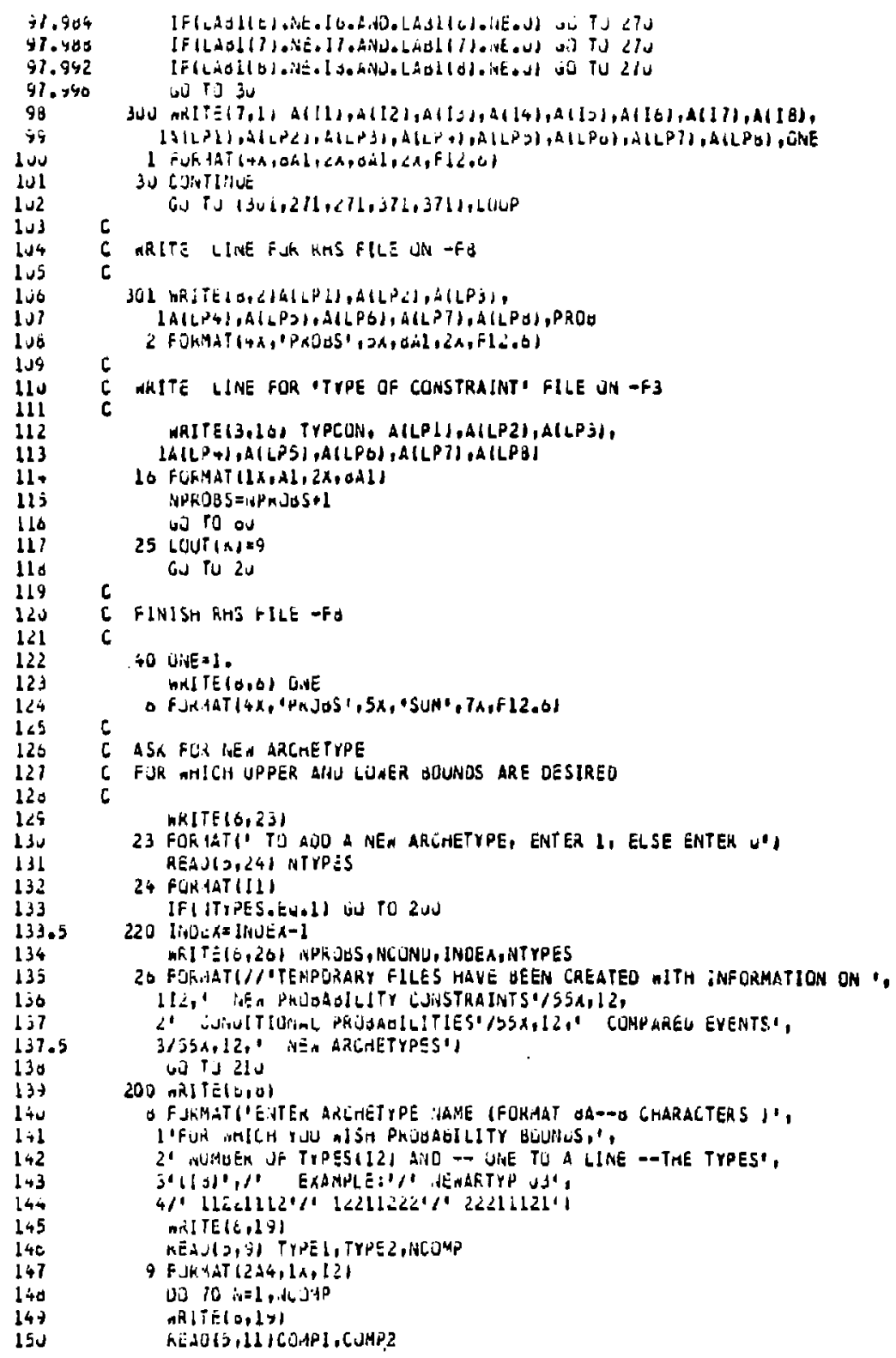




\section{FILE NAME: S.SETUP (continued)}

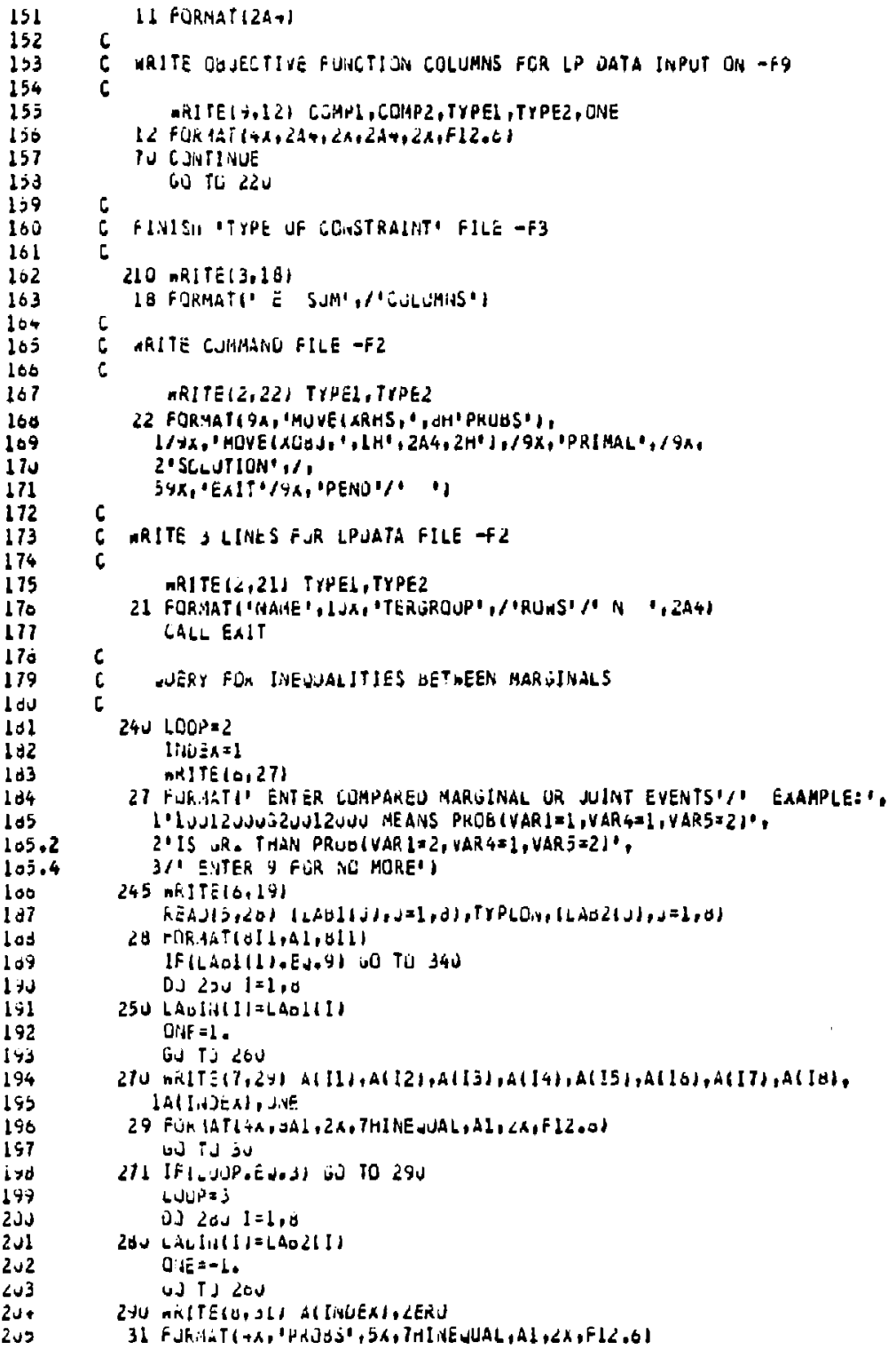




\section{FILE NAME:_S.SETUP (continued)}

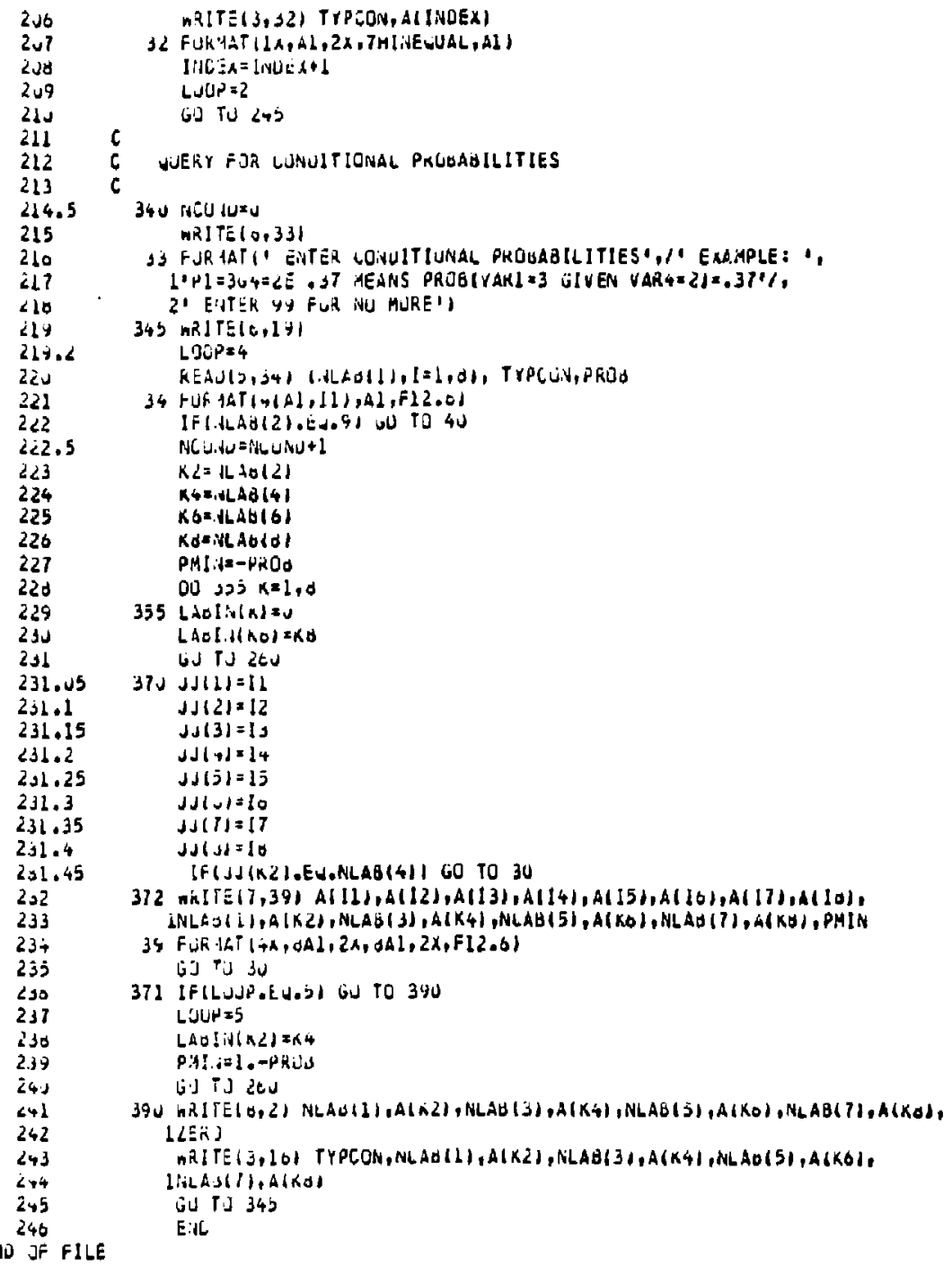




\section{TEMPORAAY FILES}

FILE NAME: -F2

\begin{tabular}{|c|c|}
\hline $\begin{array}{l}1 \\
2 \\
3 \\
4 \\
5 \\
6\end{array}$ & 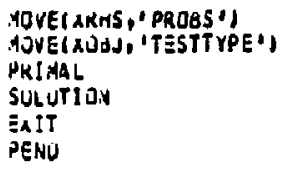 \\
\hline $\begin{array}{l}\text { MAME } \\
\text { ROAS }\end{array}$ & † EีRเROUP \\
\hline
\end{tabular}

\section{FILE NAME: -F3}

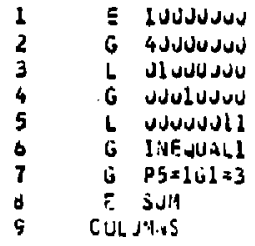

FILE NAME: F8

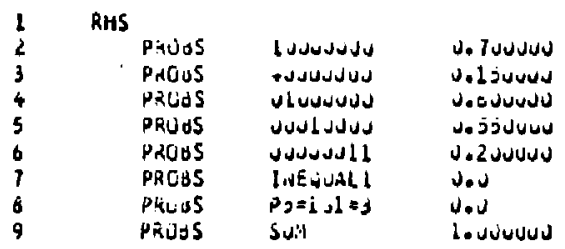

\section{FILE NAME: $\quad F g$}

\begin{tabular}{|c|c|c|}
\hline$\frac{1}{2}$ & $\begin{array}{l}111111111 \\
22222222\end{array}$ & $\begin{array}{l}\text { TESTTYPE } \\
\text { TESTTYPEE }\end{array}$ \\
\hline
\end{tabular}


TEMPORARY FILES

\section{FILE NAME: $\cdot F 7$}

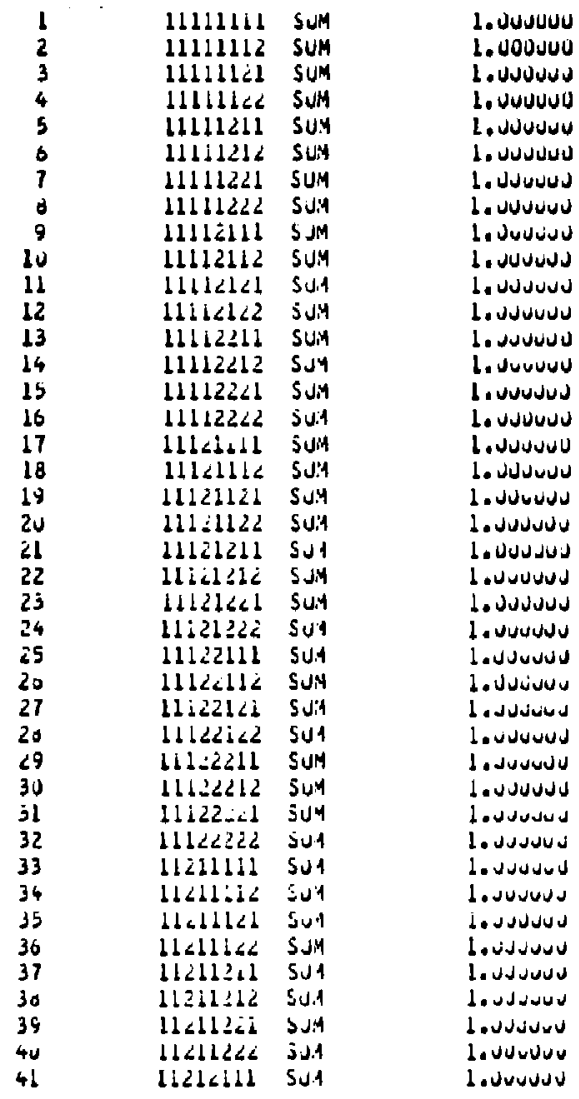


FILE NAME: -F7 (continued)

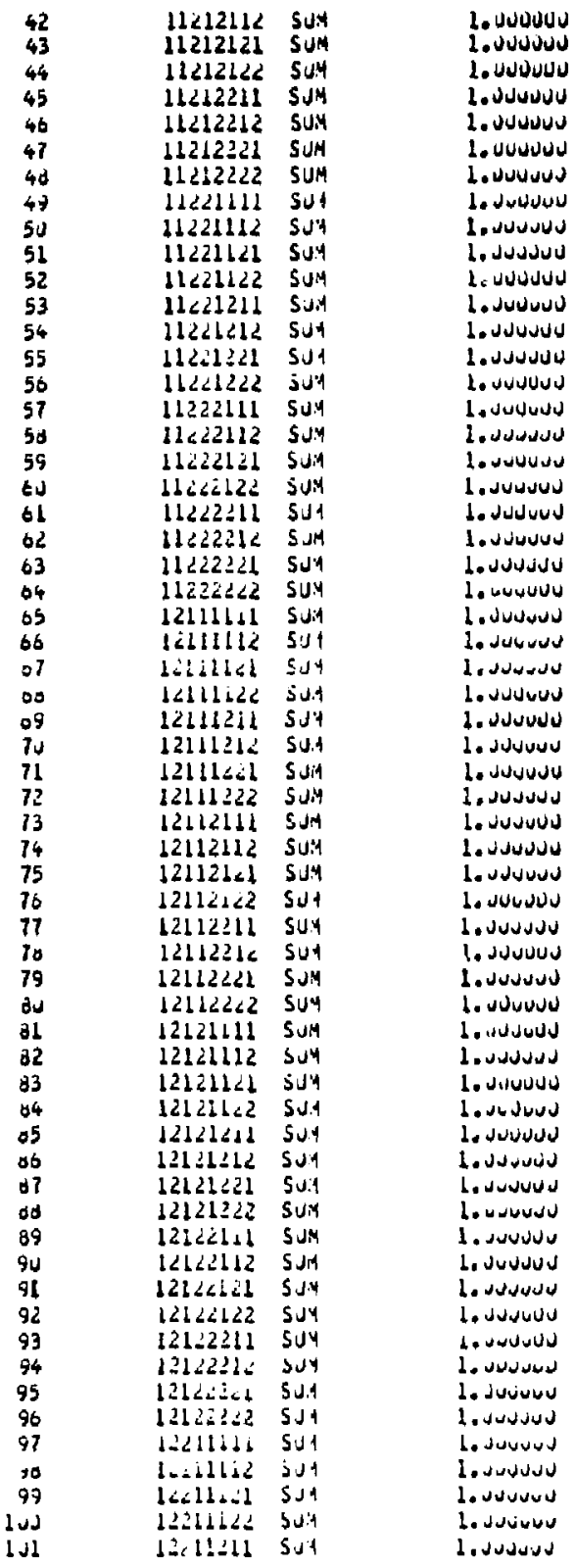


FILE NAME:-F7 lcontinued

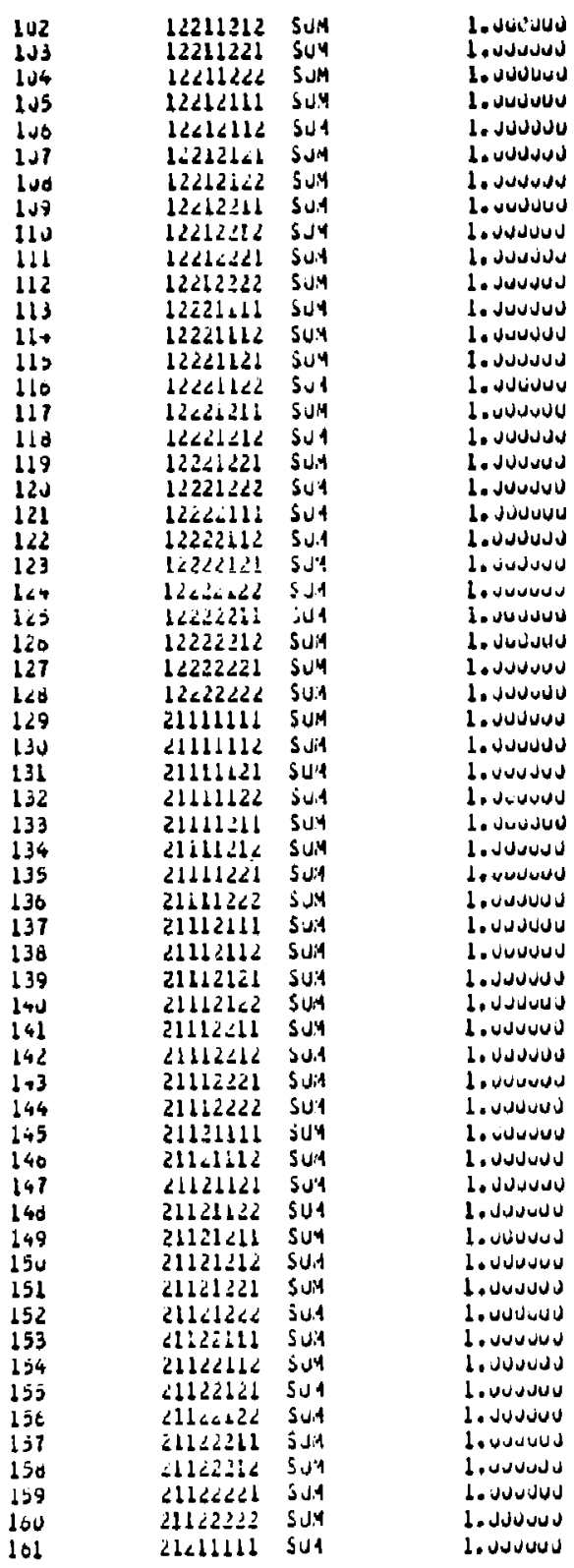


FILE NAWE: - $F 7$ (continued)

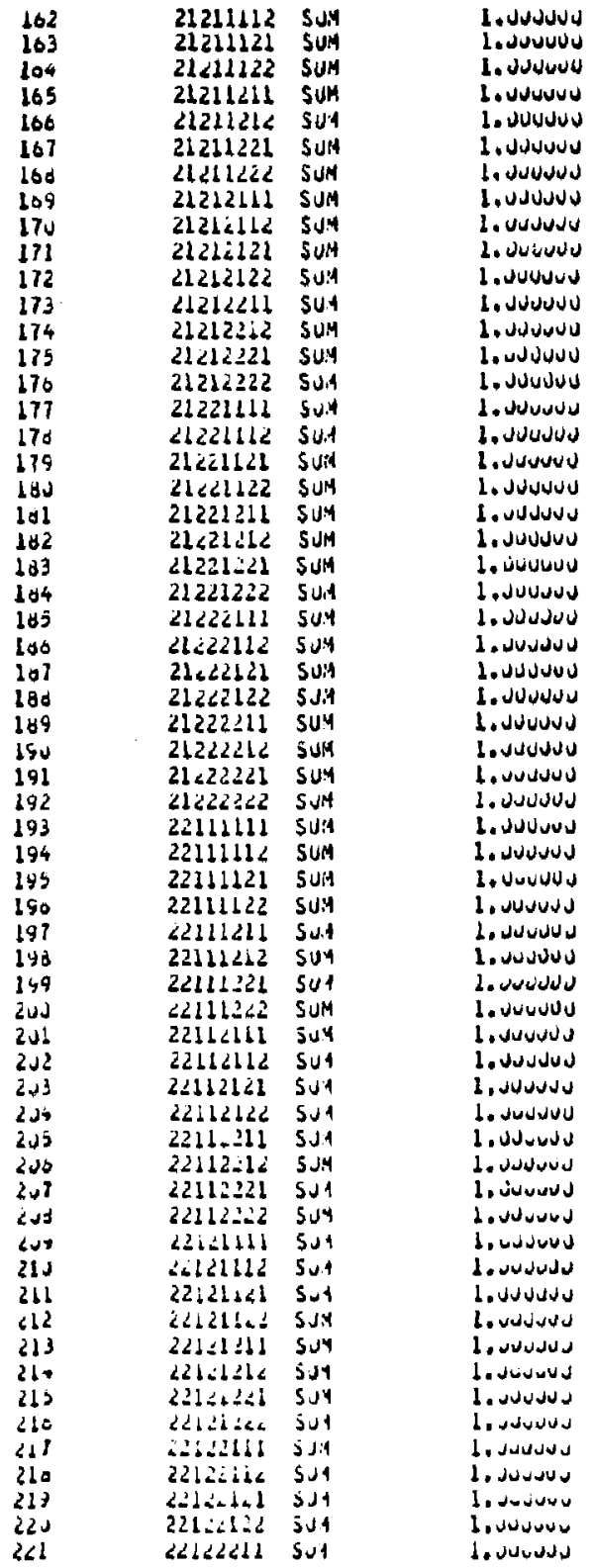


FILE NAME: -F7 (continued)

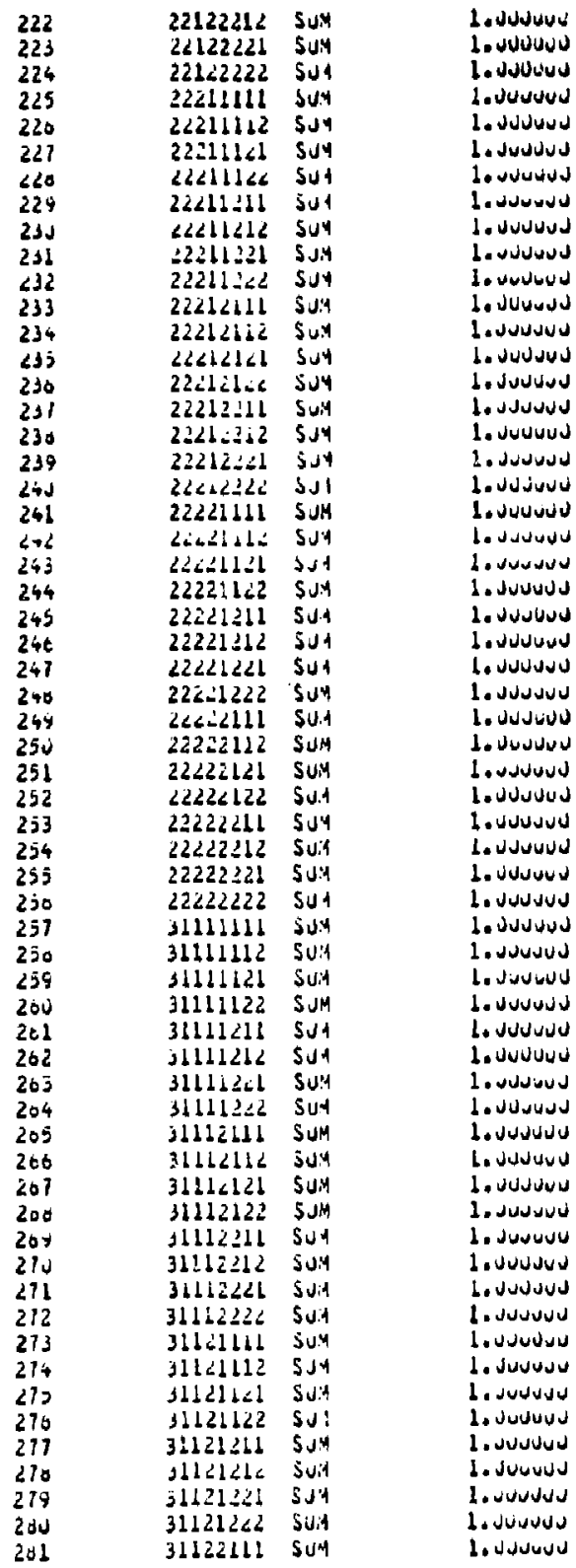


FILE NAME: -F7 (continued)

\begin{tabular}{|c|c|c|c|}
\hline 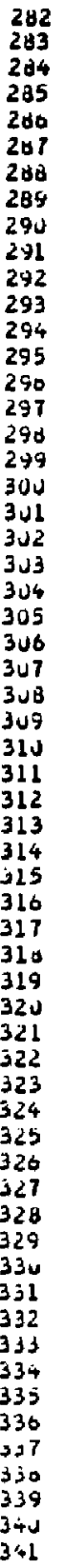 & 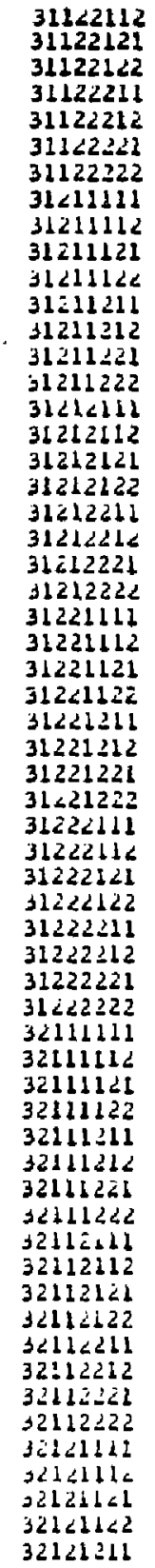 & 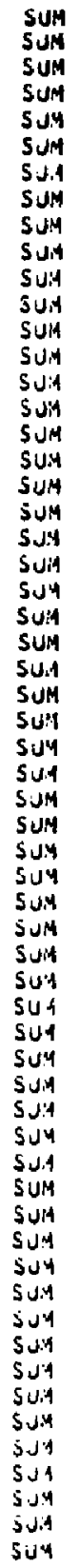 & 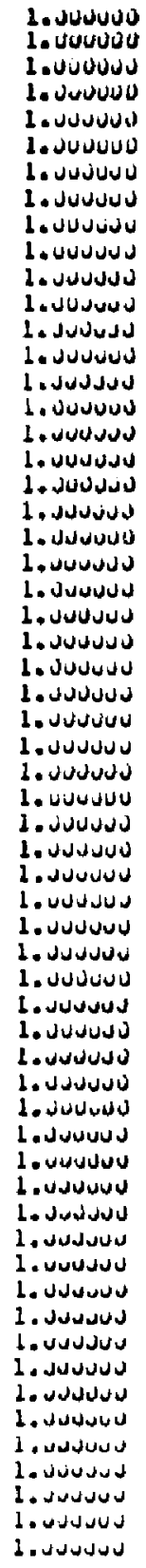 \\
\hline
\end{tabular}


FILE NAME: · F7 (continued)

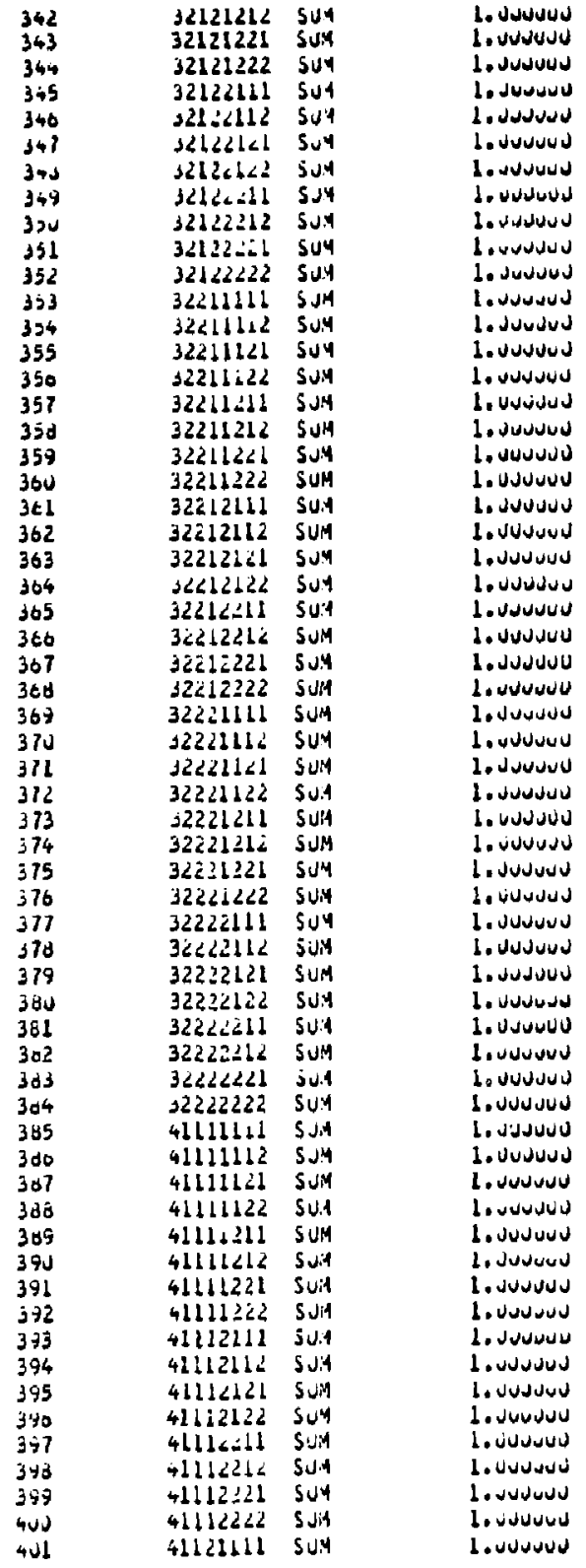


FILE NAME: $F 7$ (continued)

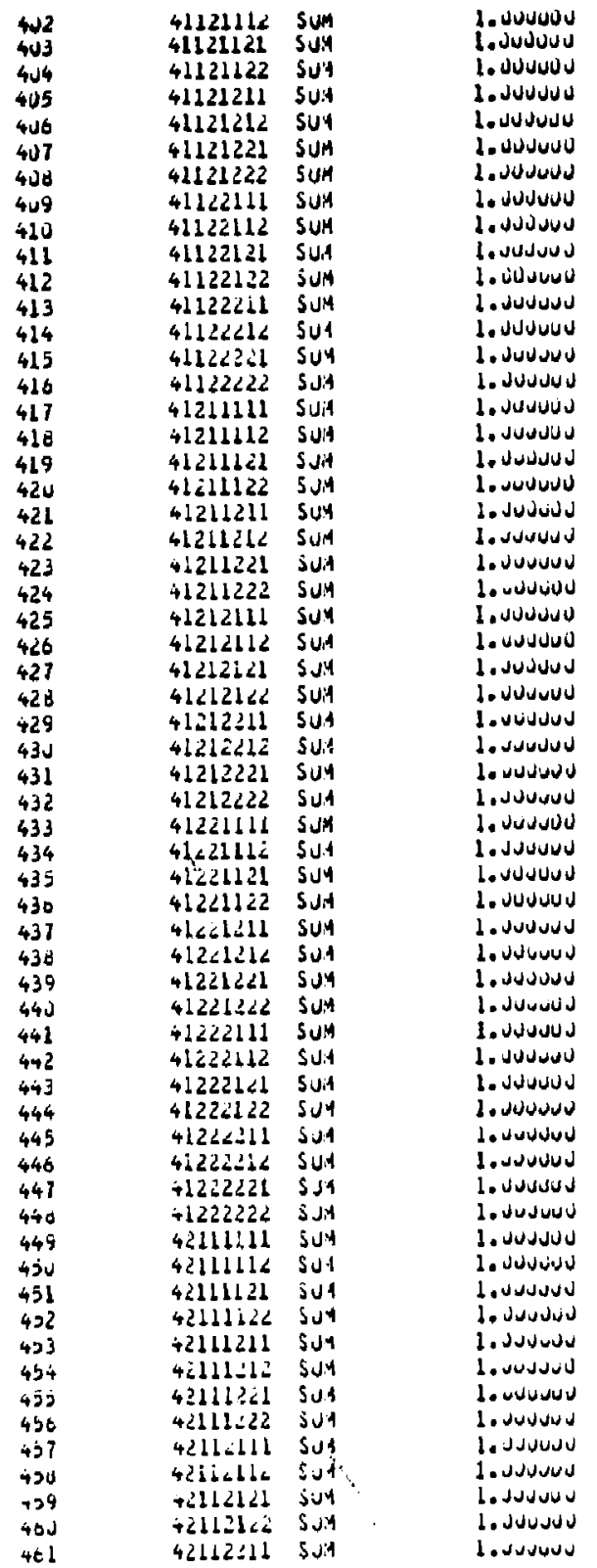


FILE NAME: -F7 (continued)

\begin{tabular}{|c|c|c|c|}
\hline $\begin{array}{l}402 \\
403 \\
404\end{array}$ & $\begin{array}{l}42112212 \\
42112641 \\
42112222\end{array}$ & $\begin{array}{l}\text { SUM } \\
\text { SUM } \\
\text { SUY4 }\end{array}$ & 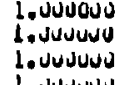 \\
\hline 465 & 42121112 & Su.4 & L d dududu \\
\hline 400 & 42121112 & SuH & l. Jusuds \\
\hline 407 & $\$ 2121121$ & SUY & 1 1. \\
\hline+0 & 42121122 & Suit & טله \\
\hline 409 & 42121211 & Suit & Louvuvau \\
\hline $47 \mathrm{~J}$ & $42121<12$ & $\begin{array}{l}\text { SuM } \\
\text { SuM }\end{array}$ & 1. JuUuUo \\
\hline 411 & 42121221 & $\begin{array}{l}\text { SuM } \\
\text { SU,4 }\end{array}$ & 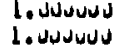 \\
\hline $\begin{array}{l}472 \\
473\end{array}$ & $\begin{array}{l}42121222 \\
42122111\end{array}$ & $\begin{array}{l}\text { Su, } \\
\text { Su. }\end{array}$ & \\
\hline 414 & 42126112 & SJI4 & 1. SJuviuu \\
\hline 473 & 42122161 & Suit & 1. Jusuuv \\
\hline 476 & 42142122 & SUI & 1. Jusudus \\
\hline 471 & 42122211 & SU.t & L. JuJueves \\
\hline 470 & 42122212 & SUM & 1. dلJuUu \\
\hline 479 & 42122221 & Su. & 1. UUJULU \\
\hline 400 & 42122262 & 5 U.4 & 1. unusus \\
\hline $4 d 1$ & 42211111 & Su.4 & 1. usunus \\
\hline 402 & 42211112 & SUH & L. JuJusJ \\
\hline 483 & $4221112 i$ & Sul: & 1. uLuJusu \\
\hline 404 & 42211122 & SUM & L. Judusud \\
\hline 485 & $42211<11$ & SUM & l. Jususus \\
\hline 486 & 42211212 & Suin & l. iduouso \\
\hline 407 & 42211621 & Sulk & 1. douvous \\
\hline $40 d$ & 42211222 & 5 S.4 & 1.JUUUUJ \\
\hline 409 & $4221<111$ & SUH & 1. Udususs \\
\hline 490 & 42212112 & SUMY & 1. UUuUdu \\
\hline $4 y 1$ & 42212121 & SU,A & 1. JuUن่Ju \\
\hline 492 & 42212122 & Suid & 1. JuvنuU \\
\hline $4 * 3$ & 42212211 & 5J4 & 1. JJUuU \\
\hline 494 & 42212212 & Sum & 1. d JuJuU \\
\hline 495 & $42<12<<1$ & 5 JM & 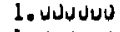 \\
\hline 476 & 42512222 & $5 u \cdot 4$ & L, JuUJuJ \\
\hline 497 & $42221 \mathrm{LI}$ & $5 \mathrm{~J}$ & 1. JuJuUu \\
\hline 49d & 42221112 & Sult & L. voujou \\
\hline 479 & 42221121 & Su,d & l. UงJuUJ \\
\hline 5 Uo & 42241122 & Su'4 & 1. NJUUuJ \\
\hline 5ul & $422212 i 1$ & $5 \mathrm{Jin}$ & 1. JuUuJJ \\
\hline juz & $422 \leq 1 \leq 12$ & S JH & 1. UuvuvJ \\
\hline 503 & +2221221 & Sun & 1. Jusuves \\
\hline 304 & $42221 \geq 222$ & Sud & 1. Juolus \\
\hline 505 & +2222111 & SJiM & 1. Juvius \\
\hline $5 J 6$ & 42222112 & Sum & 1. VLJJuJu \\
\hline 537 & $42222 \mathrm{LCL}$ & 50.1 & 1. JuJuUV \\
\hline Sud & 42622122 & SuM & 1. JuUUuN \\
\hline $5 \cup 9$ & $42 z 22211$ & 501 & 1. Juduvas \\
\hline Slv & 42222212 & Sult & 1. UUJuYu \\
\hline 511 & $42622-46 d$ & SU4 & 2. Juosudu \\
\hline 512 & $4<2222 \angle 2$ & Sud & I. vuJuJus \\
\hline 513 & dlillik & L UUUJuUs & L. duousud \\
\hline 314 & 11111612 & L JUUJuOJ & 1. Joduus \\
\hline 515 & 11111121 & L UJasugus & 1. JusJuJ \\
\hline 516 & $111111<2$ & L Juvuvou & 1. Juvunu \\
\hline 517 & $\mid 111121 !$ & 1 JuJuUQu & L. vivusud \\
\hline 510 & 11111212 & 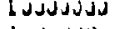 & L. Jusust \\
\hline 519 & $1111122 L$ & L Q JuUJuUu & L. jususus \\
\hline jLJ & d1LidLé & Iususviss & L. JJJuJu \\
\hline 221 & 11112111 & 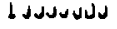 & l, unuous \\
\hline
\end{tabular}


FILE NAME: ·F7 (continued)

\begin{tabular}{|c|c|c|c|}
\hline $\begin{array}{l}522 \\
523\end{array}$ & $\begin{array}{l}11112112 \\
11112121\end{array}$ & 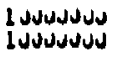 & 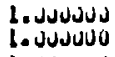 \\
\hline 524 & 11112122 & L UNUUUJuJ & 1. Juvulus \\
\hline 525 & 11112211 & \ JUJلJUు & 1. JuJuUu \\
\hline 526 & 11112,12 & IUJLUJUUJ & 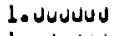 \\
\hline 527 & $1111221 \mathrm{i}$ & I UUUJJUS & 1. UUUJuds \\
\hline 528 & 11112222 & 1 JコJUএJ」 & 1. UلUUلJ \\
\hline 529 & 11121111 & I USLUSUSJ & 1. douveds \\
\hline 330 & 11121112 & L UJUUJUUS & 1. Juduvus \\
\hline 531 & 11121121 & I JUUUUUU & 1. uUuvus \\
\hline 532 & $1112+122$ & !UJUUJUJ & 1.JuUud \\
\hline 533 & 11121211 & IUUUUJUJ & 1. JuJud \\
\hline 534 & 11121212 & IUJUJJUS & 1.0.JUง \\
\hline 535 & $11121 \geq 21$ & L UJUAUNU & 1. JusuU \\
\hline 530 & 11121222 & lúJUUNJUJ & 1. UuUuod \\
\hline 537 & 11122111 & LUJUUJUU & 1. JuJuivs \\
\hline 598 & $111<21+2$ & lOJuJudus & ba juduos \\
\hline 539 & 11122121 & IUJUJuJు & 1. JuUNuU \\
\hline 540 & 11122124 & 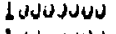 & 1. JusJud \\
\hline 541 & 11122211 & 1 UJuduvu & t. unuvu \\
\hline 542 & 11122212 & I UปJנJง & 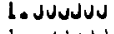 \\
\hline $5+3$ & 11122221 & IUVUJJJs & hasuoud \\
\hline 544 & 11122222 & L JunJuss & D. ovunus \\
\hline 545 & 11211111 & 1 JUUUUরU & 1. JUJuJJ \\
\hline 346 & 11211112 & 1 Jusuvud & 1. JuJusus \\
\hline 347 & $112111 \leq 1$ & 1 L̇JJuUs. & 1. Jusuu \\
\hline $5+0$ & $11<11122$ & luJuJuds & 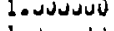 \\
\hline 549 & $11211<11$ & LUJUJuUs & 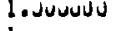 \\
\hline $55 v$ & 11211212 & lusususs & I. Jusuu \\
\hline 531 & $11<112<2$ & 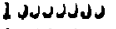 & 1. RUJUน \\
\hline 552 & $11211 \div<2$ & lidJuJuUd & 1. \\
\hline 253 & 11212111 & 1 JUJUUdJ & L. vưuv \\
\hline 554 & 11216112 & I UلdudJuJ & 1. Juosu \\
\hline 555 & 11212121 & 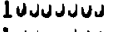 & 1. UUJJu \\
\hline 550 & 11212122 & I Jusudud & 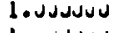 \\
\hline 537 & $11<12211$ & 1 Juvisuus & L.uuJuvu \\
\hline 558 & 11212212 & 1 UుUJJUు & 1.usuJu \\
\hline ל\$9 & 11212221 & 1 JงuJJuJ & l. JuUusu \\
\hline 500 & 11212262 & 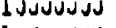 & I. Q v wuJ \\
\hline $50 !$ & 11221111 & 1 LuUvJuJ & l. susure \\
\hline 502 & 11221112 & 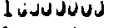 & 1. Jusjue \\
\hline 363 & 11221121 & 1 JaUUJü & 1. JuUud \\
\hline 504 & 11221122 & I LUJUSJJ & 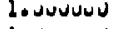 \\
\hline 505 & 11221211 & I UJUJJUJ & b. Jưua \\
\hline 560 & 11621212 & 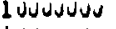 & 1. Jusuv \\
\hline 501 & 11621621 & IUJGudvo & l. Juduv \\
\hline jod & 11221226 & I UJudsus & L. Juvidu \\
\hline 569 & $1122211]$ & 1 Jusurdus & 1. 1. \\
\hline $57 \mathrm{~J}$ & 11222112 & I yuUvuns & 1. Juvaun \\
\hline 571 & 11222121 & 1 JUUปJus & 1. Juviuv \\
\hline 572 & $11222+<2$ & I UJUJJUJ & 1. Junuve \\
\hline 573 & $1122621 i$ & I usudsus & 1. Juoude \\
\hline 574 & 11222212 & l UJJJUUS & la suvuu \\
\hline 575 & $212 \leq-321$ & 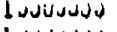 & 1. JuJuU \\
\hline 576 & $11222: 22$ & d USUJJJJs & la sugusos \\
\hline 577 & 1211111 & luduodus & [. JUJUUU \\
\hline 372 & 1211i11c & I JuUsuvus & i. JuJuU \\
\hline 57 & $121111 \mathrm{a}$ & d Uงงvงus & 1. Juvous \\
\hline 50. & $121 i 1122$ & |งUงJUง & 1. Juvueu \\
\hline $50 !$ & 12112211 & Isuvesus & 1. unuoul \\
\hline
\end{tabular}


FILE NAME: -F7 (continued)

\begin{tabular}{|c|c|c|c|}
\hline $\begin{array}{l}502 \\
5 d 3\end{array}$ & $\begin{array}{l}12111212 \\
12111221\end{array}$ & $\begin{array}{l}\text { LUUYJUJd } \\
\text { I UduUuJJ }\end{array}$ & $\begin{array}{l}\text { 1. JuUuYu } \\
\text { 1. JuJuJul }\end{array}$ \\
\hline 584 & 12111222 & I UงUJJUง & 1. JJUJUN \\
\hline 505 & 12112111 & 1 JJusJus & L. vusuJus \\
\hline$\$ 00$ & 12112116 & Jلנ Juد I I & 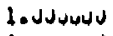 \\
\hline 507 & 12112121 & I UUUJנJ & 1. unuJuJ \\
\hline Sod & $121121<2$ & 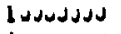 & b. Jusuaus \\
\hline 507 & 12112211 & 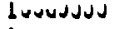 & - JusuJ \\
\hline Syu & $12112 \geq 12$ & IUJUJJנJ & 1. JusduJ \\
\hline $3 \$ 1$ & $12162 \leq 1$ & 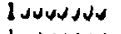 & asuso \\
\hline & $1211<222$ & 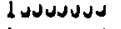 & 1. JuJuJuJ \\
\hline 545 & LL12l:iL & I UUภภUมJ & 1. Juevous \\
\hline 29. & 12121112 & LuJuJusd & ovJuJJu \\
\hline 595 & $121216 \leq 1$ & LUJงנมงU & lousunues \\
\hline 590 & 12121122 & 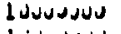 & لטلduJu \\
\hline 577 & $121212 i 2$ & lujJuJusJ & 1. usvause \\
\hline 5\%d & 12121212 & 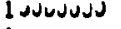 & 1. uUvuus \\
\hline 599 & 12121221 & 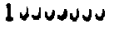 & 1. vousoss \\
\hline ous & 12121222 & 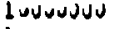 & 1. Juvuous \\
\hline bul & $121<2111$ & 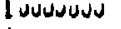 & I. unusus \\
\hline Du2 & 12122116 & loovjuss & 1. unuevas \\
\hline 003 & $1 \geq\lfloor 2 \leq 1 \leq 1$ & I Wowsusd & 1. Jusuud \\
\hline 604 & 12122122 & dusususu & lovoudus \\
\hline bu5 & 12122211 & dususuds & 1. Uuvujus \\
\hline Eu6 & $12122: 12$ & L JuUSUNS & 1. JuUuous \\
\hline bง 7 & 14122221 & LUNuUdud & 1. Juvaud \\
\hline bua & 12122262 & D JงJงJJu & 1. duvaus \\
\hline 6u7 7 & 1221111 & 1 JjusJus & 1. ovusus \\
\hline 610 & 12211112 & 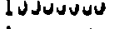 & 1. dususud \\
\hline 011 & $12 \hat{c} 11: 21$ & LUJUUUJง & 1. UงUUJ) \\
\hline 012 & 16611166 & L UUJJUUS & 1. usuruev \\
\hline$b 13$ & 12211111 & 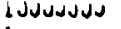 & 1. Jusuous \\
\hline 814 & 12211212 & I uusurusu & l. vousuge \\
\hline 015 & 12211221 & IJJunuas & 1. usuvusu \\
\hline blo & $12211<22$ & iudanusa & D.jugusad \\
\hline 017 & $12<12111$ & ! Uルป১งЈ」 & lovusuus \\
\hline 616 & 12216112 & 104Jusud & 1. vovusue \\
\hline 619 & $1221<121$ & IJJuJusus & L. JuUJues \\
\hline b20 & 12212122 & buJuvJưs & 1. JUUנJJU \\
\hline 621 & $12212 \pm 11$ & l UuUuduva & 1. ususus \\
\hline$\leftarrow 22$ & 12212212 & IJנบsJus & L. บงuvusu \\
\hline $62 \mathrm{~J}$ & 12212221 & 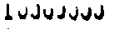 & 1. vJunus \\
\hline $0<4$ & 12262226 & 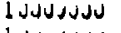 & 1. JưuJus \\
\hline 025 & $122<2 i 11$ & 1 JuUsगJง & 1. dUNUUN \\
\hline 626 & 12241112 & LUJuaJuJ & L. UNUUUS \\
\hline 027 & $122211<1$ & 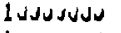 & l. Juujus \\
\hline 628 & 12221.22. & 1 desuvus & 1. suusuves \\
\hline 029 & 12221211 & 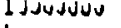 & loduguva \\
\hline 030 & 12221612 & I JuLusus & 1.0ususu \\
\hline b31 & 12221221 & ! unusuns & 1. vousus \\
\hline 052 & $12 \alpha-12 \alpha 2$ & 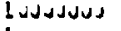 & bousurus \\
\hline 633 & 12622611 & I uvaruous & Lovousus \\
\hline 634 & 12222112 & 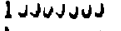 & 1. unuous \\
\hline 635 & $122 \pm 3 b 21$ & 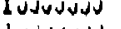 & I. SUUJus \\
\hline 036 & LLC6LLC & 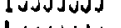 & 1. vouvas \\
\hline 037 & 12222211 & I ปコงנJงJ & I. JuJusu \\
\hline 030 & $12222 \leq 14$ & 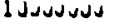 & 1. JuJusJ \\
\hline 634 & 12222421 & [บงuงdu」 & 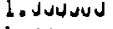 \\
\hline 640 & $12 \leq 222 \leq 2$ & bJगJงJUJ & 1. Juvusu \\
\hline $04 i$ & 1111 & 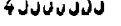 & 1. نJuUNu \\
\hline
\end{tabular}


FILE NAME: •F7 (continued)

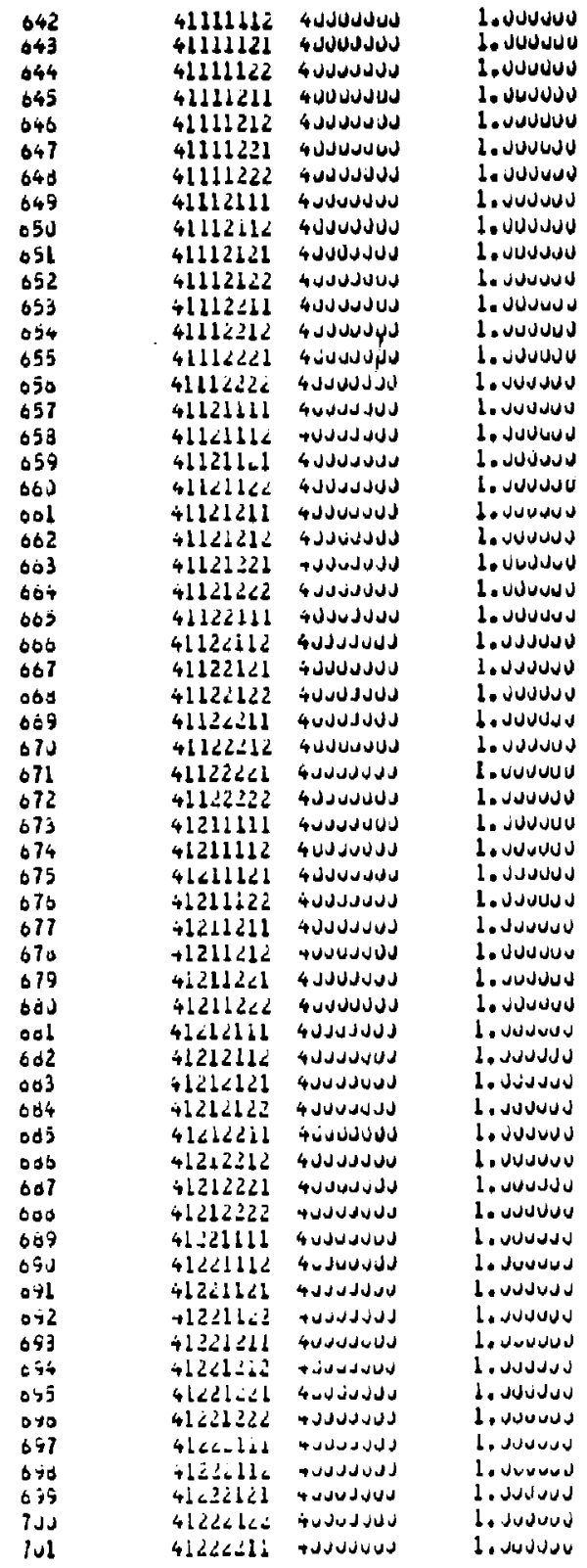


FILE NAME: - $F 7$ (continued)

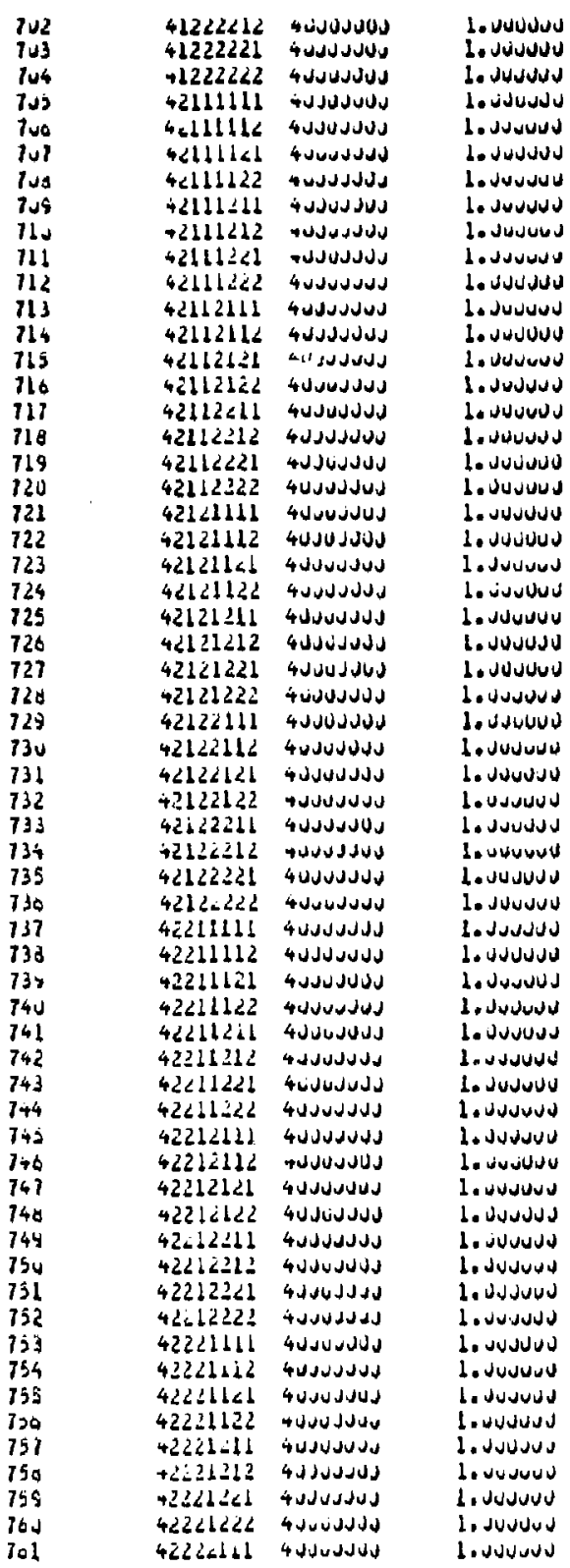


FILE NAME: -F7 (continued)

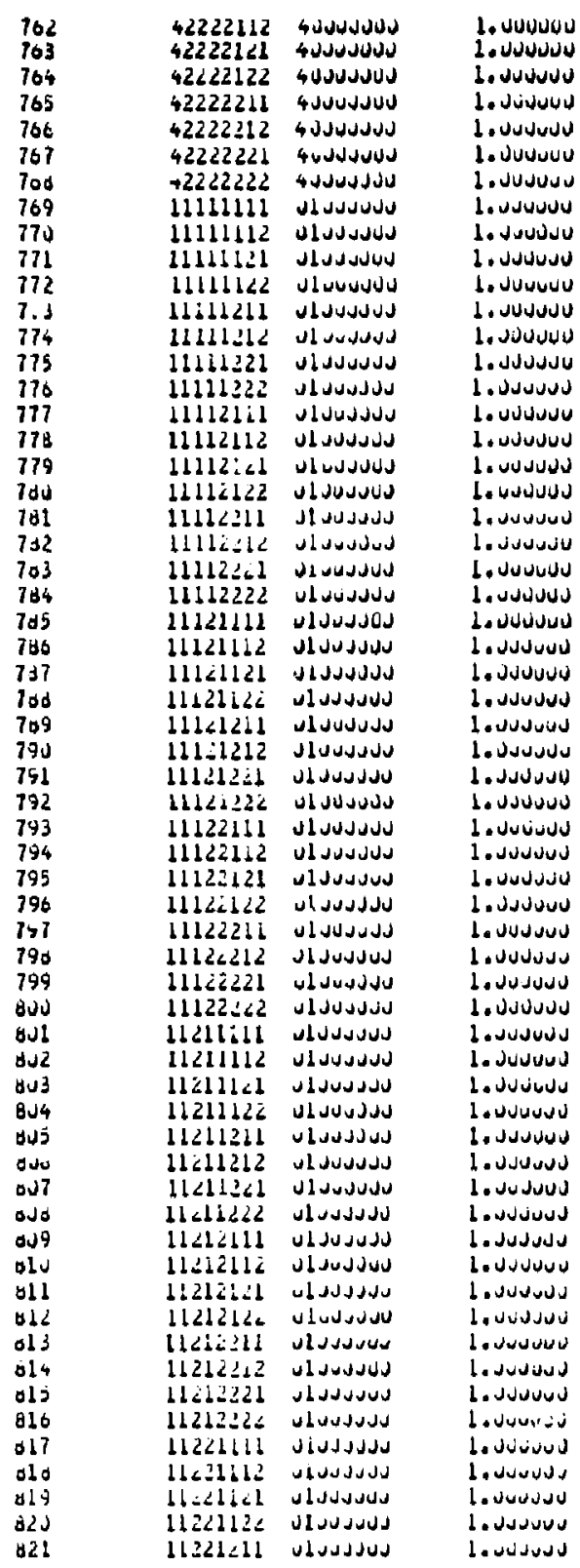


FILE NAME: -F7 (continued)

\begin{tabular}{|c|c|c|c|}
\hline $\begin{array}{l}822 \\
223 \\
324 \\
025\end{array}$ & $\begin{array}{l}11221212 \\
11221221 \\
11221222 \\
16222114\end{array}$ & 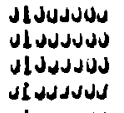 & 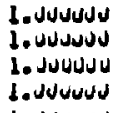 \\
\hline $8<0$ & $112 \angle 21 L$ & גנلנJuJ & 1. JUJUUN \\
\hline 021 & $11222 i 2 i$ & טגנدנل إ & 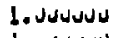 \\
\hline 020 & $112<126$ & נטJusul & I Cuddund \\
\hline 829 & 11222211 & גנلנמטגן נד & 1. dausiou \\
\hline USJ & $11222 \div 12$ & נIJUJusu & 1. Jususu \\
\hline d)! & IfcLaisl & נטנגنטג נI & 1. Juuvuas \\
\hline 032 & 11222222 & دנل دلهد إט & נגנטנטיט 1. \\
\hline$d j 3$ & Lllldd! & U JuJUUJ J & 1. JUNUUJ \\
\hline 854 & 21111112 & 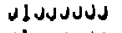 & 1. Jلdusus \\
\hline 635 & $211141+1$ & UIUUJuJJ & La dJUJJU \\
\hline 830 & $211111<2$ & טلנدנטالט & 1. JuUuJu \\
\hline 037 & 21111211 & Juدנ إ & 1.Jusuds \\
\hline 030 & $2 ! 11 ! 2+2$ & UI UUJJUU & L. duvous \\
\hline 839 & $2 ! 111221$ & 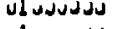 & 1. vuavus \\
\hline$\theta+v$ & L11112á & JโงuJJuJ & 1. Jujusu \\
\hline $8+1$ & $211+\bar{b} b 11$ & נلנטנגנגט & b.JJuJuo \\
\hline$B 42$ & 21112114 & 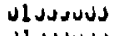 & 1. Uutuud \\
\hline 843 & 21112141 & 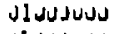 & 1. UUUUUJ \\
\hline$d+4$ & 21112122 & JIJUdudv & 1. JNuUUS \\
\hline 345 & 21112211 & UIJנטJנJ & L. UJuJuUd \\
\hline $8+0$ & 21111212 & טโుJJปుJ & L. JUUUUJ \\
\hline 847 & 21112221 & U1 JUJUUN & 1. JJUUNJ \\
\hline 848 & $2111<222$ & JLUUUJdU & 1. UUUUJU \\
\hline 049 & $21 \downarrow 21111$ & UIJUJJU & Jلנ \\
\hline $65 \mathrm{~J}$ & 21121112 & 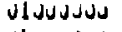 & 1. Jundoud \\
\hline 651 & $211616 ? 1$ & ปLUJปJుJ & 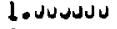 \\
\hline 852 & 21121122 & ULJנdusd & Lovavaus \\
\hline ه 53 & $211=1212$ & 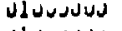 & 1. Junuva \\
\hline 454 & 21121212 & 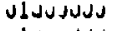 & 1. JUNuJJ \\
\hline$d 55$ & 21121221 & งl১udJJJ & 1. Jususu \\
\hline b56 & $211212 \leq 2$ & נIJUJUు & 1. Uuvad \\
\hline 457 & 21122111 & Ulduvuds & 1. JuUdus \\
\hline d 53 & $211<2112$ & JluUdJus & 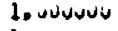 \\
\hline d59 & $211221 \leqslant 1$ & dluUdosus & 1. suvusu \\
\hline$d 60$ & 21122122 & ULJJJUUJ & 1. Juvuvius \\
\hline 601 & 21122211 & لנJנدנג J1 & 1. Juvisus \\
\hline 862 & $21 ! 22112$ & JluusJud & 1. vusuous \\
\hline 863 & 21142221 & دUلردلإل & to suouve \\
\hline do4 & 21122322 & J1 JusJus & do univous \\
\hline 865 & 61211111 & נلטل لرد إل & 1. voudue \\
\hline 806 & 21211112 & נLUJuJu & 1. Jususus \\
\hline$\$ 67$ & $212111<1$ & נنנلנulu & Uטuטנג1. \\
\hline 860 & $21<11122$ & נلנגנلטגט טג & 1. JuUurv \\
\hline 069 & $21211<11$ & 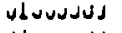 & L.suJusus \\
\hline $87 \mathrm{~J}$ & $2621+212$ & 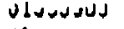 & douvduru \\
\hline 871 & 21611221 & 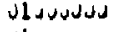 & 1. Junusus \\
\hline 872 & 21,211222 & 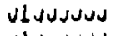 & 1. Jududvo \\
\hline 473 & $21 d 12111$ & visuosus & 1. suvulue \\
\hline 074 & 21212142 & טIJURJuJ & 1. duvurug \\
\hline 675 & $21212+<1$ & Uluvdudu & 1. Judurus \\
\hline 676 & 21212126 & Jluvdusu & 1. Jusuvus \\
\hline 677 & $21212: 11$ & J! JUUנJJ & losususus \\
\hline 070 & $21+1<-12$ & נلנدטנטأט & 1. UะUงJu \\
\hline 019 & $4121+221$ & IงטנJתנ & 1. Jususud \\
\hline 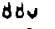 & 21212226 & UtנdנJJu & 1. UJUNJU \\
\hline sol & 1 & vluvusud & inev \\
\hline
\end{tabular}


FILE NAME: -F7 (continued)

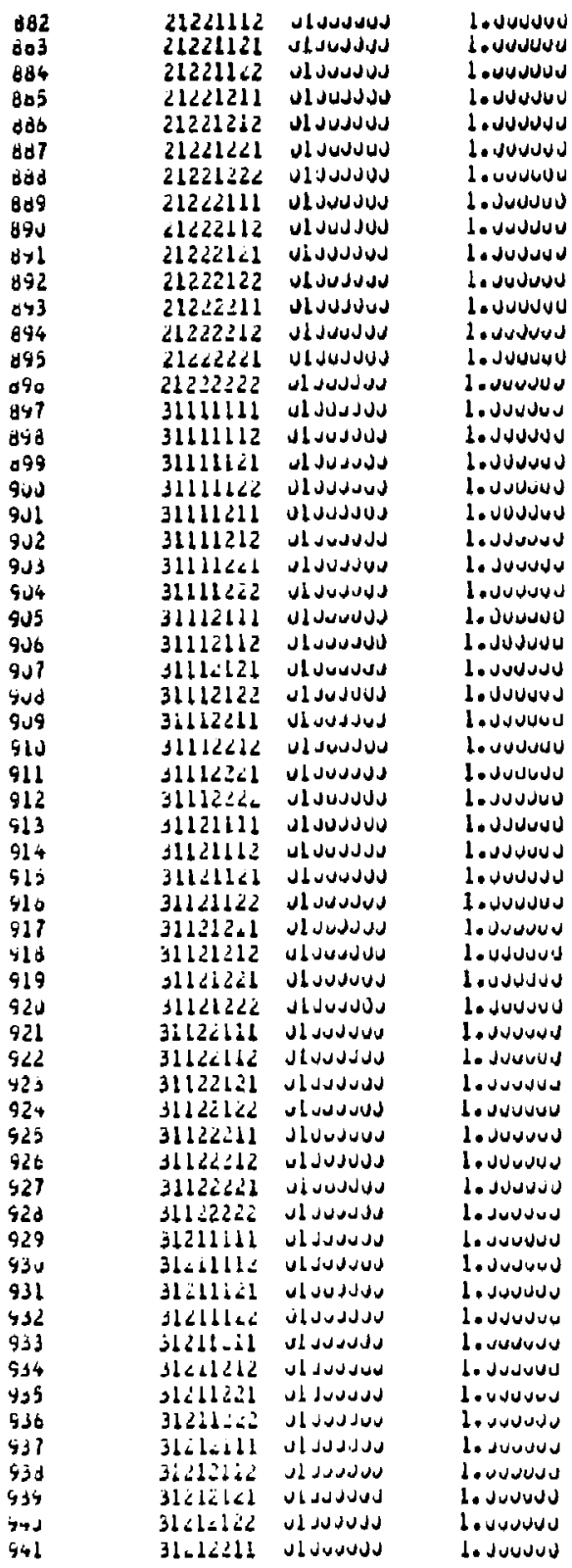


FILE NAME: ·F7 (continuęd)

\begin{tabular}{|c|c|c|c|}
\hline $\begin{array}{l}942 \\
943\end{array}$ & $\begin{array}{l}31212212 \\
3121222 i\end{array}$ & 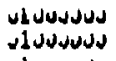 & 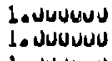 \\
\hline 446 & 31212242 & JLUUJUUS & 1. uJusuov \\
\hline 945 & 31221111 & נلدل الט إل & 1. doudand \\
\hline 946 & 31621112 & 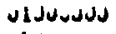 & 1. JuUdus \\
\hline 947 & $312<1121$ & טlJUJJUS & 1. USunud \\
\hline ying & 31241122 & Whoudusu & 1. Jusious \\
\hline 949 & allal_ll & 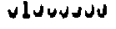 & Loduvueu \\
\hline 950 & $1+2 \geq 1212$ & desdusu & L.JuYvoJ \\
\hline Il & $21221 ? \leqslant 1$ & 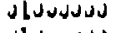 & bauvives \\
\hline 952 & 31221222 & U1JUUJJJ & 1. Juvavus \\
\hline 953 & SLCLdl] & v1 duvuJu & L. unsusu \\
\hline & 31222112 & UluovoJs & lo saduesu \\
\hline 955 & $312221<1$ & L JuJuJu & 1. dusuves \\
\hline 950 & 31226142 & ULJUJJUS & Le vousuos \\
\hline 957 & $312-2311$ & 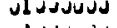 & 1.Jugudud \\
\hline $95 d$ & $31<22 \leq 12$ & ULJUJusJ & La duosuos \\
\hline 558 & $\$ 12223<1$ & 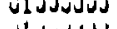 & 1. Jusucos \\
\hline 764 & $31222<22$ & J L JUJJJJ & bovdousue \\
\hline 901 & 41111111 & JI JUUJJU & 1. jususua \\
\hline 502 & $-1 i l 1 i_{2}^{2}$ & נI JUJuJJ & 1. Jusurus \\
\hline $4 \varepsilon 3$ & $41111+21$ & 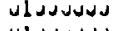 & 1. JuUudv \\
\hline 904 & 41111122 & UI JUJJUJ & 1. JUJuUso \\
\hline 965 & 41111211 & Jl JuUsus & LoduduUd \\
\hline 966 & 41111212 & ULUJJJJJ & 1. J44Jus \\
\hline 907 & 41111221 & II JuJus & 1.0Jusus \\
\hline 900 & 41111222 & UL UUJUSJ & 1. SuJudul \\
\hline 909 & $4111<111$ & JIJUJuUJ & Loveunus \\
\hline 97. & 41112112 & J1 JJuvdu & 1.0NQJue \\
\hline $97 !$ & $4111<121$ & Ul JNJJUS & de usundor \\
\hline 972 & 41112122 & J! JUUJUS & 1. U U Uud \\
\hline 973 & 41112211 & I LuJdUd & - o Juasoso \\
\hline 274 & 41112212 & JL JuJJuJ & 1. vuvuvv \\
\hline 975 & 41112221 & J! JUปJuJ & 1. vUNuUs \\
\hline 976 & 41212222 & 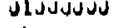 & ba dusuvas \\
\hline 977 & 41121611 & vi JuJuUJ & 1, Jud d \\
\hline 970 & 41121112 & 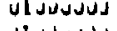 & LouvuJuU \\
\hline 979 & $41121+2 t$ & JIUJdJds & 1. Judusu \\
\hline 980 & 41121122 & UI UJJJJJ & 1. Junusus \\
\hline 981 & 41121211 & 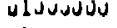 & 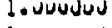 \\
\hline$F 42$ & 41121212 & 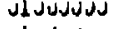 & 1. VUUUNU \\
\hline 583 & 41121261 & ULJJJJUU & 1. Q U JUJuJ \\
\hline 904 & 41121222 & ป! JปJנUJ & 1.JUJJuJ \\
\hline 965 & 41126111 & 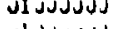 & 1. JUปJJJ \\
\hline 906 & +1162112 & Ul Ju.suJs & 1. vdugus \\
\hline 907 & 41122621 & Jl JJuJJv & 1. Jusuous \\
\hline 980 & $41122 b 22$ & UI UUJJuJ & L+ vovuงv \\
\hline 484 & 41122314 & 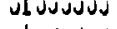 & 1. vusuaso \\
\hline צ9u & $4: 122: 12$ & 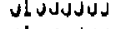 & l. Jusuusu \\
\hline 991 & 41122221 & 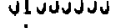 & 1. usuuvus \\
\hline 992 & $41122: 32$ & U1JuJJנJ & 1. ovusus \\
\hline 941 & 41211316 & VLJUJUJU & voudss \\
\hline 494 & $4121+12$ & UL SJ DJUJ & 1. asudus \\
\hline 995 & $4: 211: 21$ & Jl JuJJuJ & 1. Jusuded \\
\hline 996 & +1211122 & U1JUJUJJ & 1. uvaudid \\
\hline$y 97$ & $4121 ! 216$ & Uh JJJJus & 1. \\
\hline $5 \times 6$ & $+12+1<1<$ & Ul JuJJuiv & do dusura \\
\hline 597 & $41 / \mathrm{ll}-21$ & 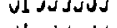 & daverusu \\
\hline lovon & 41211226 & 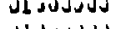 & 1. dusuad \\
\hline LUग! & 41216111 & JIJUJJUJ & 1. JUUلরU \\
\hline
\end{tabular}


FILE NAME: ·F7 (continued)

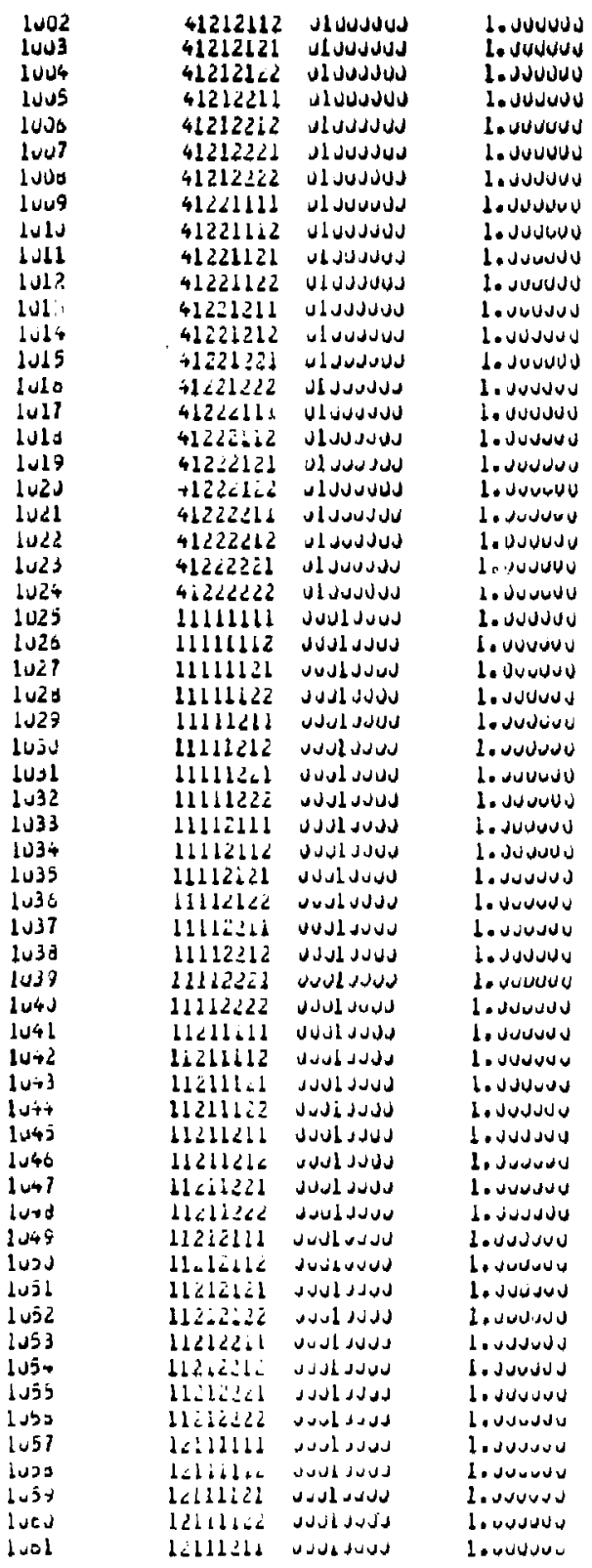


FILE NAME: .F7lcontinued)

\begin{tabular}{|c|c|c|c|}
\hline 1002 & 12111212 & 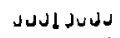 & davound \\
\hline 1003 & $12111 \leq 11$ & נטנJ J ¿נט נ & 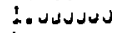 \\
\hline 1064 & 12111222 & טللده إدند & טلנטلده ... \\
\hline 1065 & $12123: 11$ & נטUנ إטن . & Jטuטגניל \\
\hline 1066 & $12112 i 12$ & vuulduds & 1. uyuduos \\
\hline iv6 7 & $121161 \leq 1$ & נJULSנUJ & 1. A.JuUuJ \\
\hline lubd & $12 ! 642 \leq 2$ & 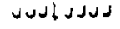 & LaUJudad \\
\hline bueg & $1211 i ? 11$ & נلנJul Ju & bousuvos \\
\hline IU70 & 12112212 & 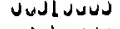 & L.usuuvu \\
\hline $107 !$ & 12112421 & נدنנ إטנر & 1. suUusJ \\
\hline 1072 & 12112224 & Jטנل إUנر & d.ouvusu \\
\hline 1473 & 12211111 & 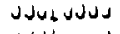 & 1. Juvusus \\
\hline Iu 74 & 12216116 & 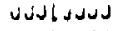 & 1. ULuUud \\
\hline 1075 & 12211121 & 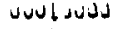 & 1. UJuovs \\
\hline 1070 & 12212122 & טUג' & 1. LUUJus \\
\hline 1077 & 12211211 & נטנג إנטג & 1. 1. vavusus \\
\hline 1070 & 12211212 & נUנJUJUנJ & L.uvuunJ \\
\hline 1079. & $122 ! d \alpha<\downarrow$ & 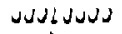 & 1. jusurus \\
\hline โบ83 & 12211222 & JuslJנJJ & 1. Jusuos \\
\hline LUล! & 12212111 & 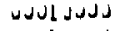 & 1.vטJued \\
\hline $10 \mathrm{dz}$ & 12216112 & UvuldduJ & 1. oujusus \\
\hline 1083 & $12<121<1$ & JULIJUJU & b.urusud \\
\hline 14B:- & 11212122 & Sund duU & 1. surudses \\
\hline 1US5 & $1221221 i$ & 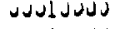 & 1.JuUuus \\
\hline Luso & $1<\angle 12212$ & 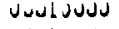 & 1. Jusued \\
\hline Lus? & 12212221 & 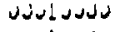 & d. juuvos \\
\hline 1080 & $122 L 2 \geq 22$ & 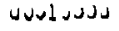 & 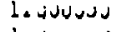 \\
\hline luds & 21111112 & נJנ」JנJ & 1. JuJuuJ \\
\hline $1 \cup 50$ & 21111112 & טJנU إJנU & 1. oviunas \\
\hline 1051 & $211111<1$ & 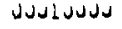 & 1. aJudus \\
\hline 1052 & $21111+22$ & Јコט!」JコЈ & l.usjuus \\
\hline 1043 & $21111 \leq 11$ & JuJl JuJs & [.ఎงЈJJป \\
\hline 1054 & 21111212 & UUن & 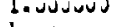 \\
\hline 1092 & 21111221 & JコJL JUJJ & l. uUuJus \\
\hline 1496 & 21111222 & JuJl JuJuJ & 1.ưvuus \\
\hline 1097 & 21162111 & 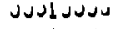 & 1. JuUJus \\
\hline 1レ98 & $2+1121+2$ & UUulJJUU & 1. נコטJנJง \\
\hline 1097 & $211+2121$ & U山U」JJUJ & 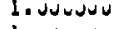 \\
\hline 11uv & 21112122 & vنuLl JuJu & 1.JJvusJ \\
\hline 1101 & 21112211 & 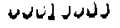 & 1. vouuds \\
\hline 1132 & 26112212 & Jugludusu & i. Juvaud \\
\hline 2103 & $21112 \div<1$ & 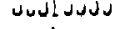 & 1. نuvusu \\
\hline $11 \sqrt{4}$ & 21112322 & 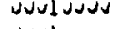 & 1. unuuvus \\
\hline 1105 & 21211111 & 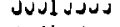 & 1. 1. \\
\hline 1100 & $21211+12$ & JUมเปJuJ & Lonuvuse \\
\hline 1107 & 21211121 & JUנL JuUJ & 1. Juvuisu \\
\hline 1100 & $212111<2$ & JУJ!JUנJ & 1. Juvisu \\
\hline 1104 & 21211211 & 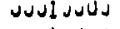 & 1.Junusu \\
\hline 111J & $3121+212$ & 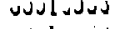 & i. usuusud \\
\hline 1111 & $212 ! 1 \leq 21$ & 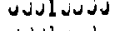 & 1. duvusus \\
\hline 1212 & 21211222 & Jus!gudu & 1. viviuous \\
\hline 1113 & 2.212121 & 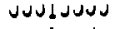 & 1. JuภusJ \\
\hline 1116 & 21212112 & لנدנ إمدנ & Lounuusur \\
\hline 1165 & $\angle 126 \angle 2=1$ & UUJbUJU, & l. Q ivuJus \\
\hline 1116 & 21212166 & JuUidudu & bajjuvos \\
\hline 1116 & $2121<211$ & 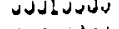 & L. voưus \\
\hline 1118 & 21212216 & JUUL & 1. juouds \\
\hline 1119 & 21612621 & 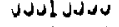 & 1. vujusus \\
\hline 1120 & 21212242 & 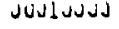 & d. vouvuJ \\
\hline 1121 & 22111111 & נגבט וטנט & 1. 1. \\
\hline
\end{tabular}


FILENAME: -F7 (continued)

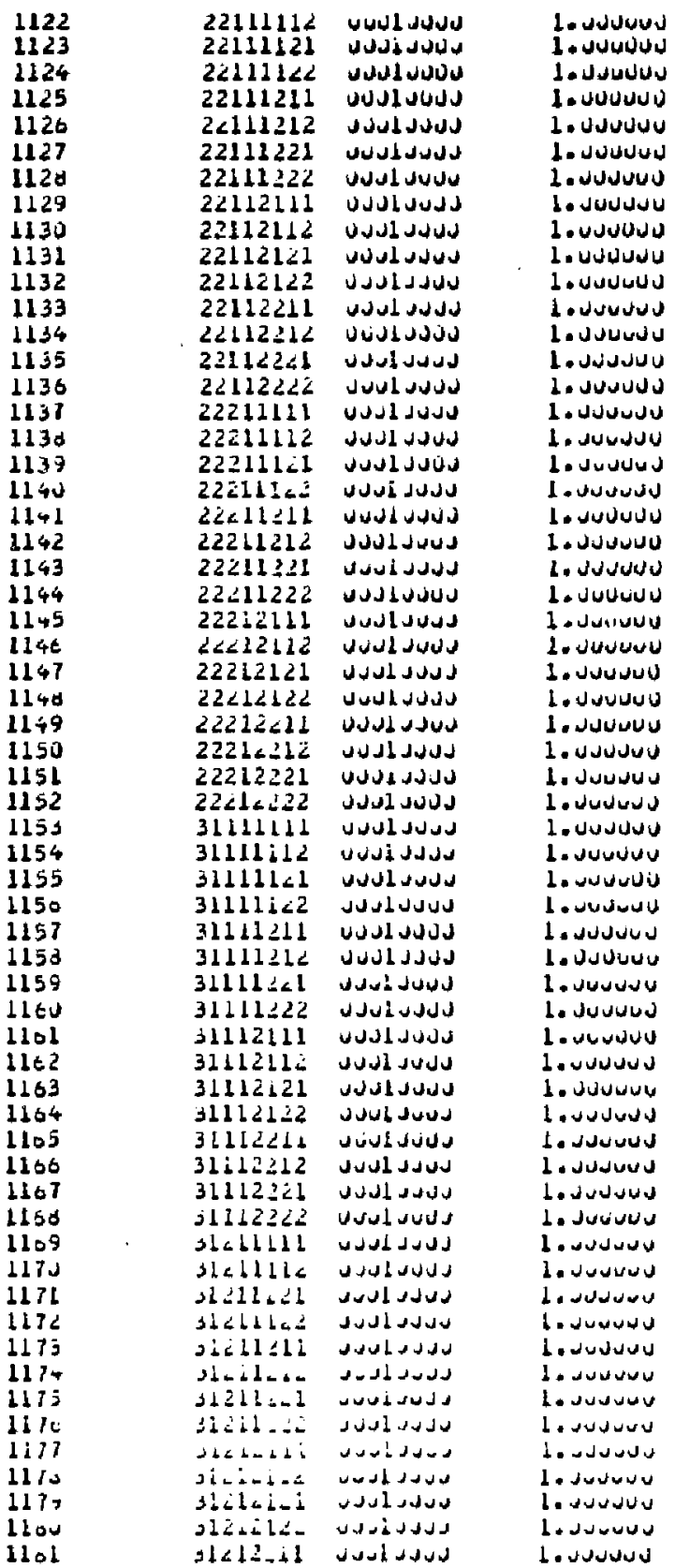




\section{FILE NAME: \&F7 (continued)}

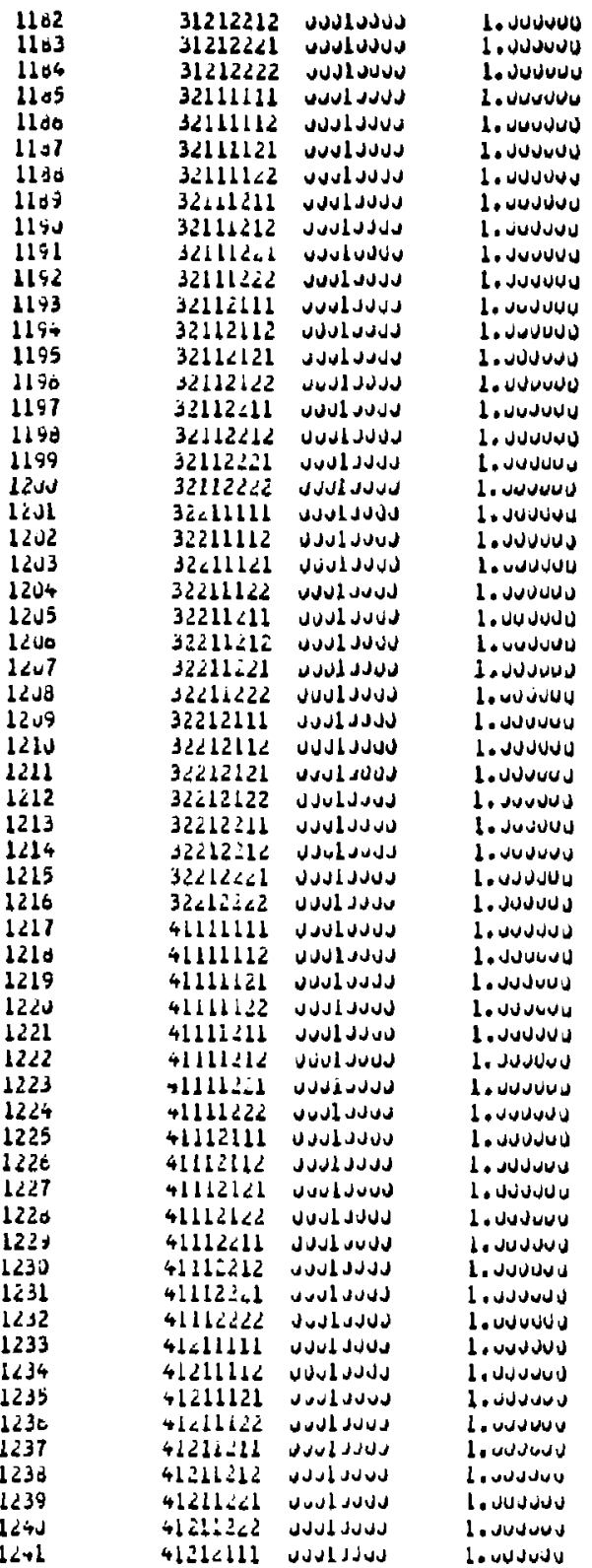


FILE NAME: $\cdot$ F7 (continued)

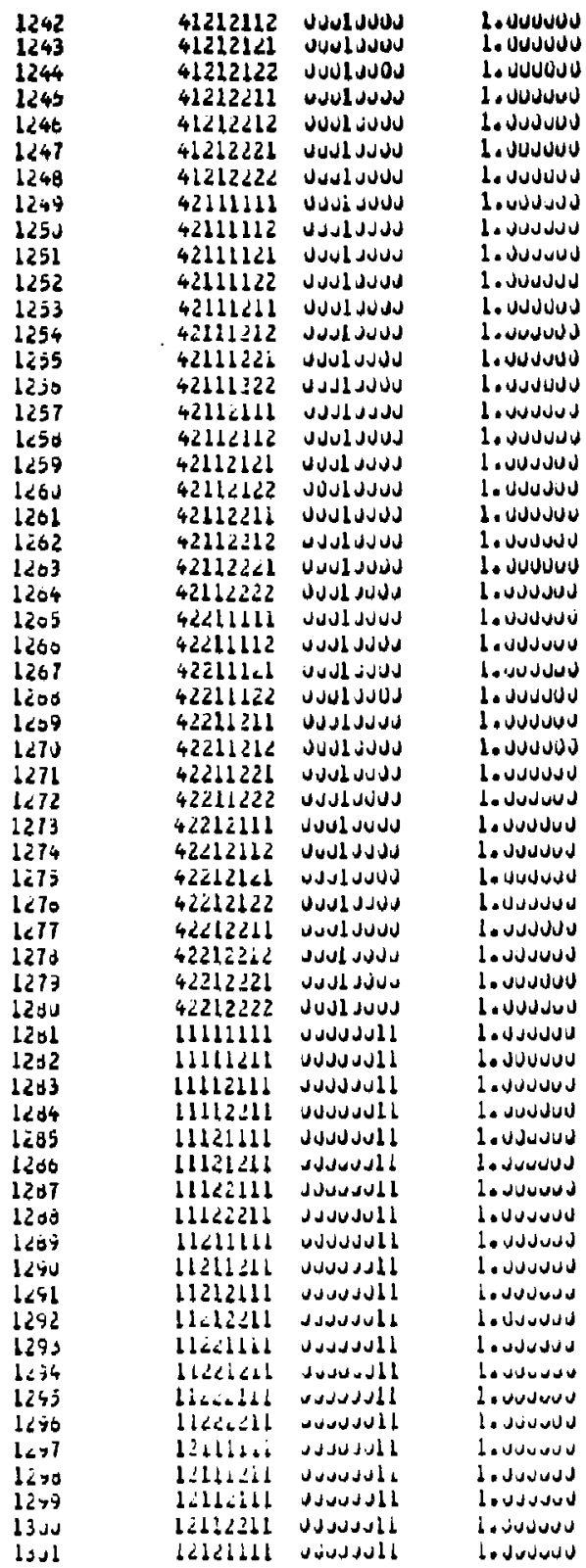


FILE NAME: $\cdot$ F7 (continued)

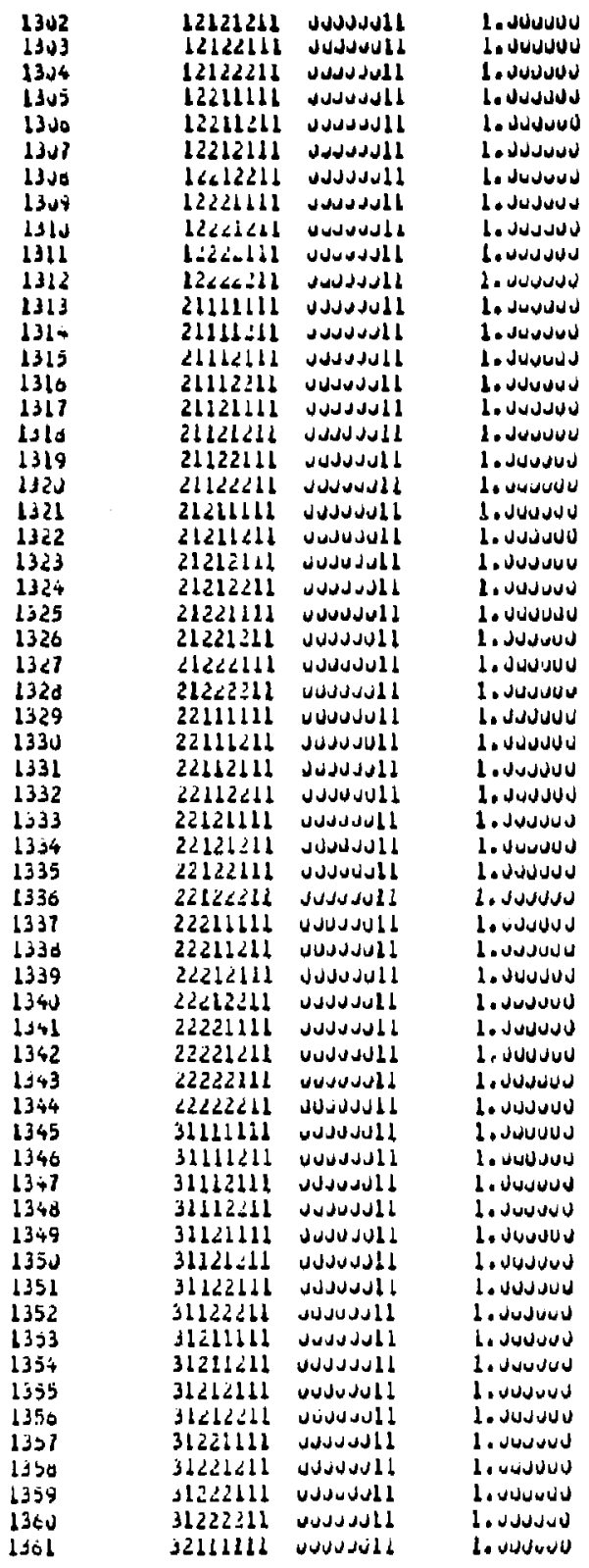


FILE NAME: -F7 (continued)

\begin{tabular}{|c|c|c|c|}
\hline $\begin{array}{l}1362 \\
1363\end{array}$ & $\begin{array}{l}32111211 \\
32112111\end{array}$ & 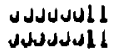 & $\begin{array}{l}\text { 1. unvousu } \\
\text { l.uvusuov }\end{array}$ \\
\hline 1364 & 32112211 & ద UuJull & 1. duuvuru \\
\hline 1305 & $12\lfloor<\rfloor \downarrow \downarrow \downarrow$ & Uududull & 1. uUuluv \\
\hline 1360 & 32121211 & งปปJงULI & 1. vusuuv \\
\hline 1367 & $3212<111$ & טdJuUJll & 1. 1. Ju'Jus \\
\hline 1300 & $32122<11$ & لUUUلU & 1. usuviou \\
\hline 2369 & 32211111 & JuJudul 1 & 1. UuJunu \\
\hline $137 \mathrm{~J}$ & $32211 \leq 11$ & UJUUJULl! & 1. UUd \\
\hline 1371 & 12212111 & נUUJJปll & 1. Jusuvus \\
\hline 1372 & 32212611 & uduoudLII & 1. UUJusus \\
\hline $13 / 3$ & $32221 i 11$ & 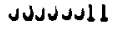 & 1. Jususus \\
\hline 1974 & 32621211 & JusJudl! & b. unusur \\
\hline 1375 & $3<<<<1 \mid 1$ & JuJujull & 1. Junuved \\
\hline 1216 & 322.2211 & 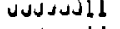 & 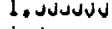 \\
\hline Ls?7 & 41611646 & JUJUSJ!! & Le viviuge \\
\hline 1316 & 41111211 & U UJJull & 1. . נUJuUs \\
\hline 1374 & +1112111 & 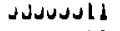 & do jususus \\
\hline 1380 & 41112211 & UUJuJd1! & ل \\
\hline 1301 & 41121111 & ل ULusull & louruoud \\
\hline 1302 & $411<1<16$ & UuJusull & 1. dusudes \\
\hline Lid3 & $41 k 62111$ & Uงusdull & L. vudued \\
\hline $138 \div$ & 41122211 & JuJusuld & 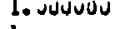 \\
\hline 1305 & +1211111 & JJJUגUIl & L, Juvusud \\
\hline 1306 & $4+1=11=11$ & ปJUנJנll & ¿. UUUJus \\
\hline $13 \mathrm{~d} 7$ & 41212111 & UUJJUULL & 1. Juuvus \\
\hline 13dB & 41212211 & 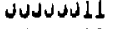 & 1. vounos \\
\hline 1359 & $41<<1 d 11$ & JüJugll & 1\rfloor . J \cup \cup \cup v$ \\
\hline 1370 & 41221211 & UJJUdull & 1. UJuUud \\
\hline 1391 & $4122<111$ & Jusudull & 1. Juปsuు \\
\hline 1342 & 41222111 & טנגJudן & dodudous \\
\hline 1343 & 42111111 & 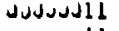 & L. unuosus \\
\hline 1154 & 42111211 & susurusll & 1. Jusuous \\
\hline 1355 & $4211<111$ & UJuUJull & 1. מusugu \\
\hline 1390 & $421+2211$ & UงJusult & 1. Juduus \\
\hline 1347 & 42131111 & טلduuJ1L & 1. vousus \\
\hline 1390 & $+c+21=11$ & JuJJuงli & L. Juvoud \\
\hline $15+4$ & 42122111 & งנJugull & 1. Jusuav \\
\hline l+uJ & $7<12 \pi \leq 11$ & גוגנJנJנ & 1. Jusudu \\
\hline$|+v|$ & $46 \leq 11+11$ & UUJJüLl & 1. disugud \\
\hline $1+\sqrt{2} 2$ & 42211211 & دUدנJIII & 1. JuJJus \\
\hline $1+03$ & 424 lcilit & 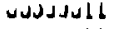 & 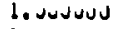 \\
\hline t+ot & $+2+1<-11$ & טudadsll & dounduos \\
\hline $14+5$ & $92 z 2 i i b i$ & ل11 & b+vouvus \\
\hline loJt & $+2 \leq+164$ & 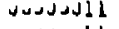 & lovesusu \\
\hline$|+2|$ & ratoctli & - & lousurous \\
\hline Itse & $r 22<a \leq 11$ & 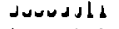 & 1. Jusuda \\
\hline 10,1 & LIILALI & $\downarrow \triangleleft \approx \cap J \Delta L b$ & נטגנים 1. \\
\hline $1+6$ & 2111111. & $1 \therefore-2061$ & 1. DJuUu \\
\hline $1=1 i$ & ciilili-i & 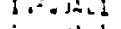 & 1. J 1 \\
\hline $\ln 12$ & atiliaten & i $1=0.2 \div$ & lasuruses \\
\hline 1011 & al. $11=i d$ & $|\Delta=\sin |$ & dosvouse \\
\hline $1 \cdot 1$. & taiciats & $i \because a, 1: a$ & indrugu \\
\hline+12 & $=1111 \ldots+$ & 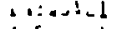 & Loususur \\
\hline 1062 & clbll2:2 & 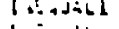 & berrowd \\
\hline $1+11$ & attiondl & 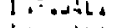 & 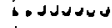 \\
\hline $1 \cdot i 3$ & clatidat & $1:=\Delta-1$ & Ladounos \\
\hline $1+1$, & allatid & $100 \operatorname{dint}$ & 1.dunavd \\
\hline 272 & $\begin{array}{l}211+2+42 \\
4 i 12 b i 1\end{array}$ & INEALI & 1. JuJ JuJ J \\
\hline $1+\ldots 1$ & Cillaid & LOENALD & L. vunuJu \\
\hline
\end{tabular}


FILE NAME: - F7 (continued)

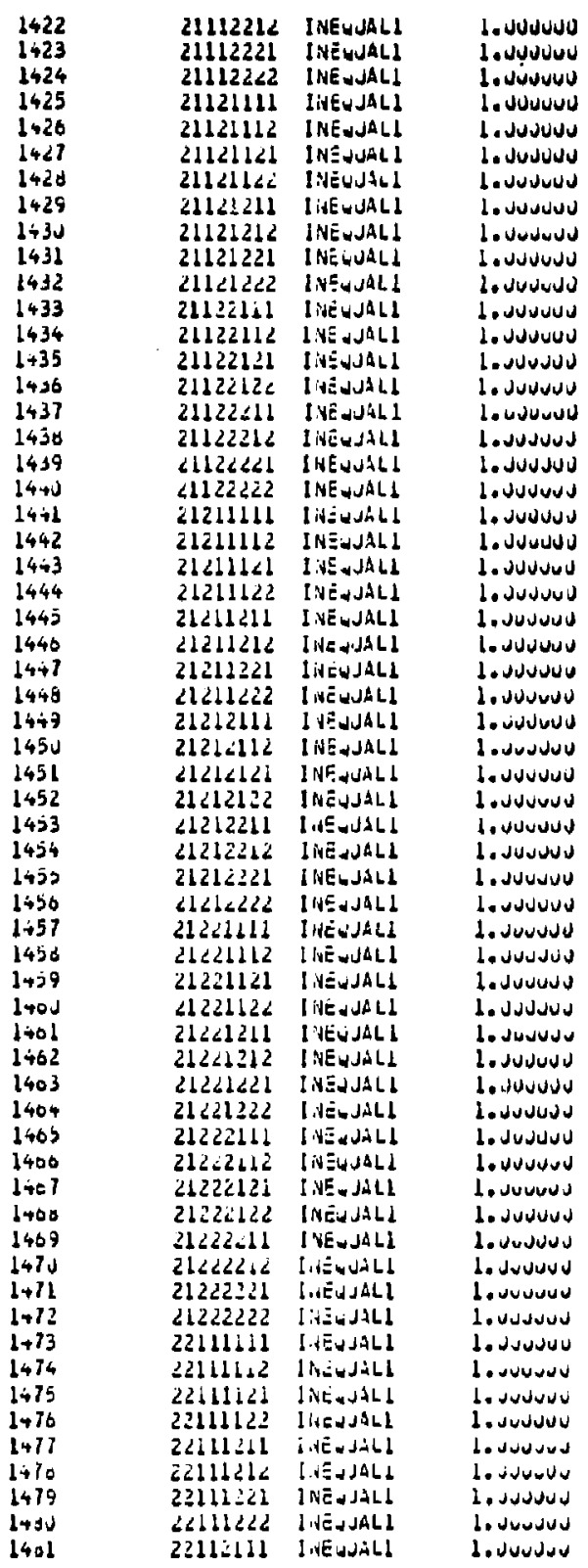


FILE NAME: -F7 (continued)

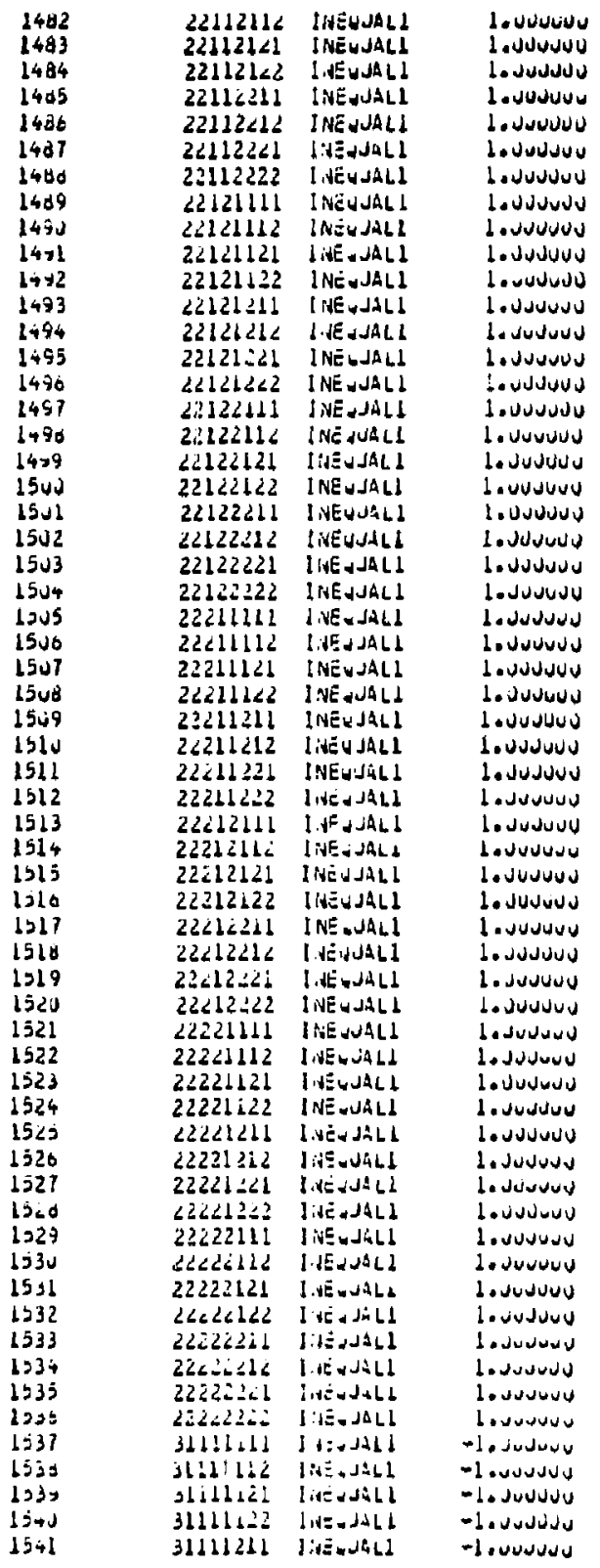


FILE NAME: F7 (continued)

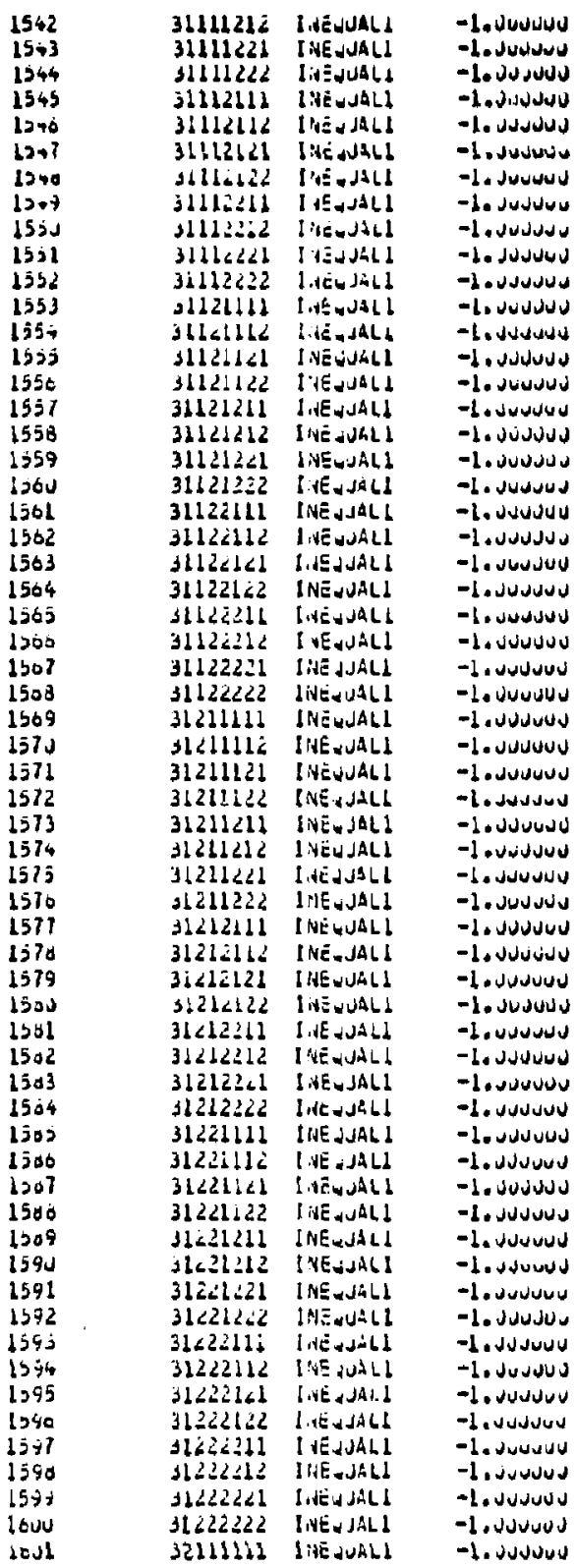


FILE NAME: -F7 (continued)

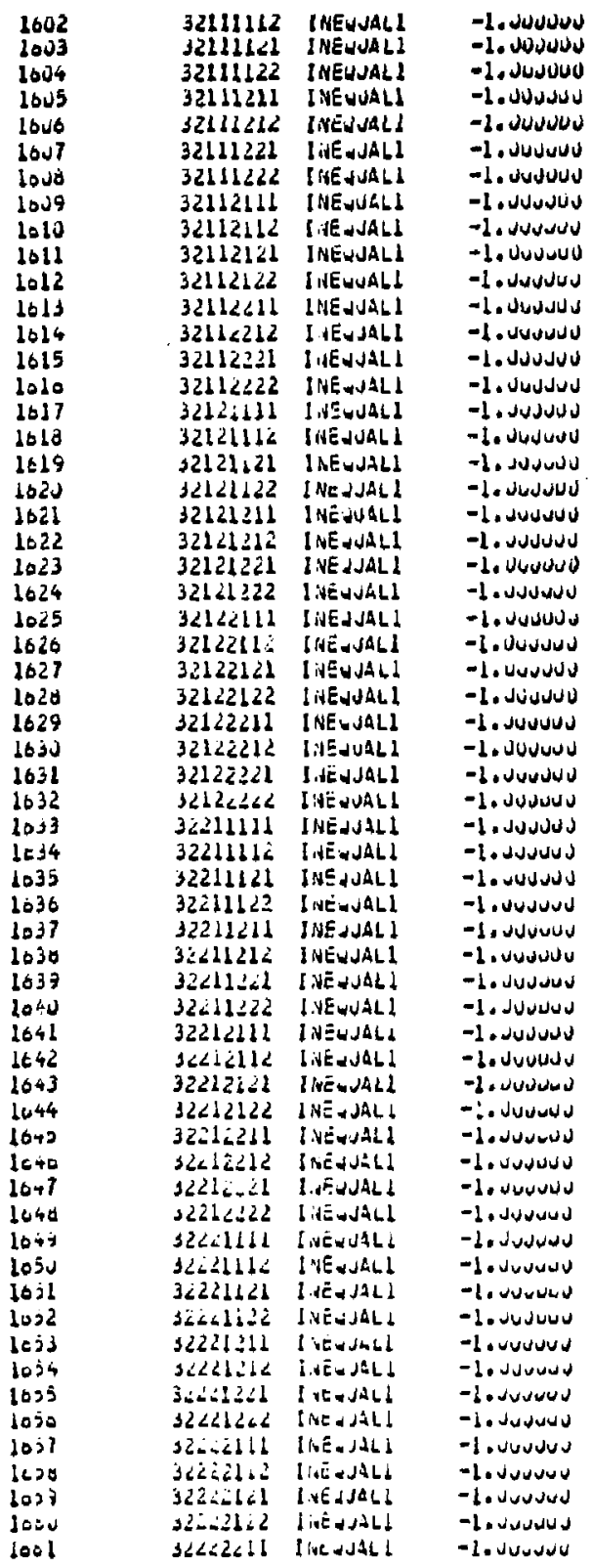


FILE NAME: -F7 (continued)

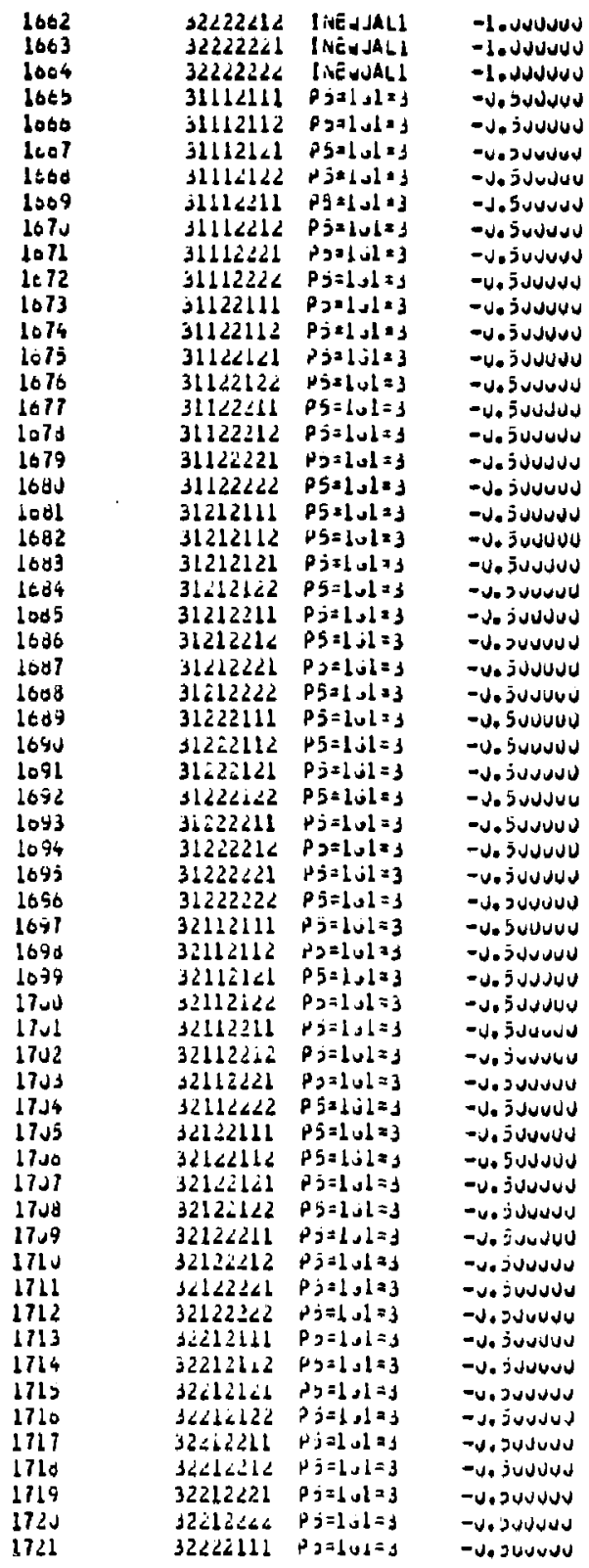


FILE NAME: $\cdot F 7$ (continued)

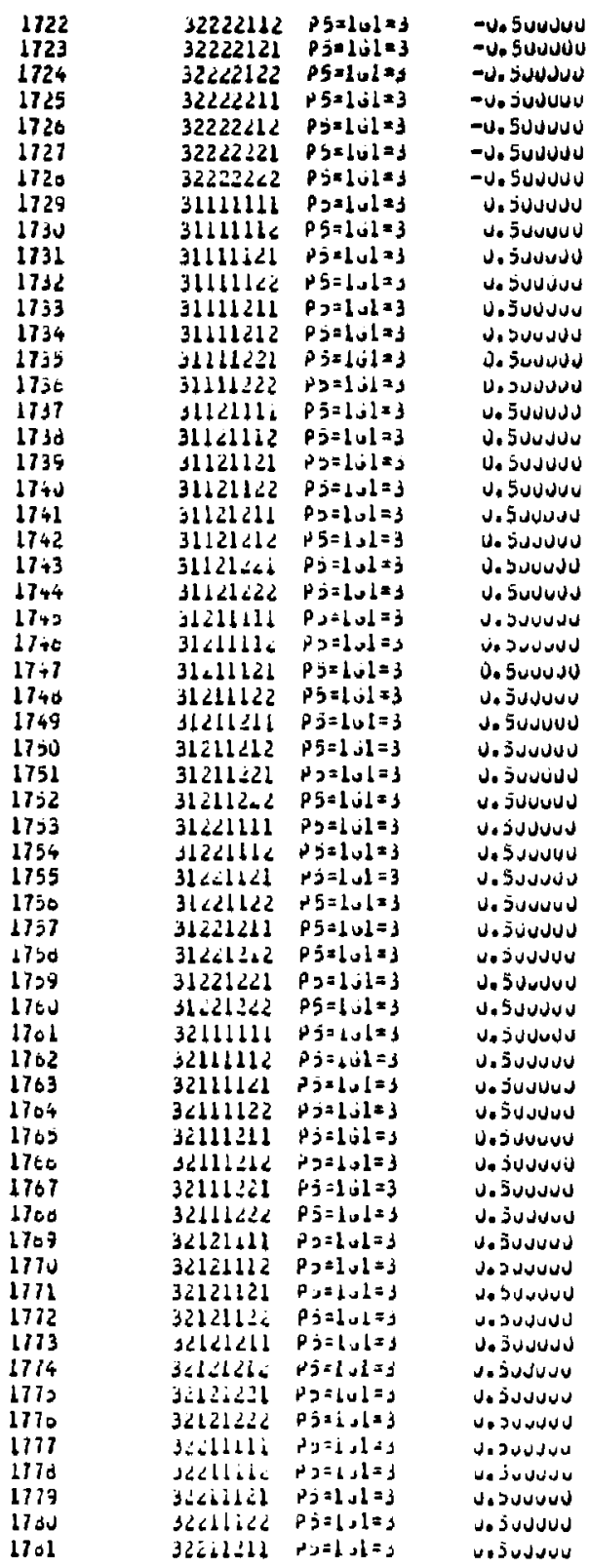


FILE NAME: $F 7$ (continued)

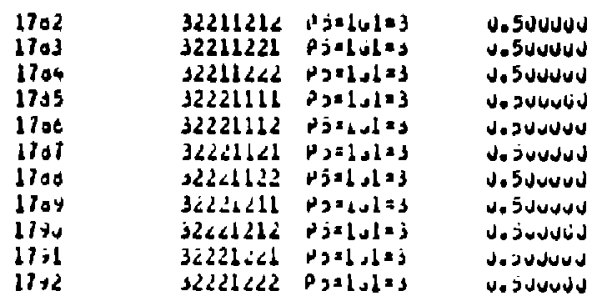

